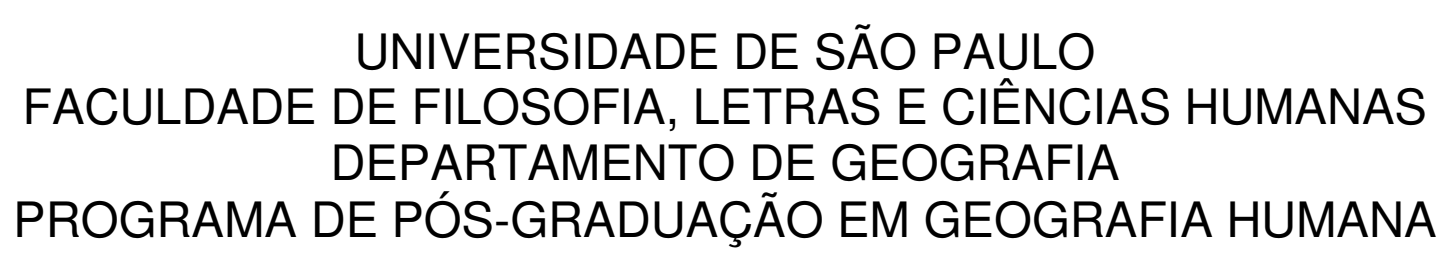

ÁGUAS TRANSFRONTEIRIÇAS SUPERFICIAIS:
o caso da bacia do rio Danúbio

Sinval Neves Santos 
UNIVERSIDADE DE SÃO PAULO

FACULDADE DE FILOSOFIA, LETRAS E CIÊNCIAS HUMANAS

DEPARTAMENTO DE GEOGRAFIA

PROGRAMA DE PÓS-GRADUAÇÃO EM GEOGRAFIA HUMANA

\section{ÁGUAS TRANSFRONTEIRIÇAS SUPERFICIAIS: \\ o caso da bacia do rio Danúbio}

Sinval Neves Santos

Dissertação apresentada ao Programa de Pós-Graduação em Geografia Humana da Universidade de São Paulo para a obtenção do título de mestre, sob orientação do Prof. Dr. Wagner Costa Ribeiro.

São Paulo 2005 
Aos meus pais

que, por meio de muito trabalho,

viabilizaram minha formação. 


\section{Resumo}

\section{Águas transfronteiriças superficiais: o caso da bacia do rio Danúbio}

Acompanhamos, nas últimas décadas, a temática ambiental se transformar em um dos principais desafios para a humanidade. Sua dimensão transnacional, alcançada quando os limites naturais não coincidem com os limites políticos, potencializa a complexidade da problemática. Em conseqüência, temas como sustentabilidade e segurança ambiental passam a ocupar posições de destaque na agenda internacional, fato que demanda novas interpretações da concepção clássica de soberania.

A questão das águas transfronteiriças superficiais - águas que escoam sobre bacias hidrográficas internacionais - representa uma materialização dos desafios mencionados acima, sobretudo porque esses recursos correspondem a maior parcela da água doce superficial e estão sujeitos a severas ameaças. Entre elas: 0 consumo excessivo de estoques hídricos limitados, que vem provocando uma crise de escassez; além dos antagonismos inerentes à necessidade de compartilhamento desses recursos, que motivam concorrências entre distintos interesses nacionais. Em função disso, surgem preocupações e questionamentos referentes à capacidade de a água gerar, ou acirrar, tensões internacionais.

Partindo das intrínsecas relações entre território e política, essa dissertação identifica as variáveis ligadas ao potencial conflitivo/cooperativo das águas transfronteiriças superficiais. Em meio a essa tarefa, temos oportunidade de discutir como os novos temas da agenda internacional incidem nessa questão.

A análise da bacia do rio Danúbio, como estudo de caso, comprova que as águas transfronteiriças superficiais podem deteriorar as relações entre países e que circunstâncias geográficas e políticas são cruciais na definição dos interesses dos Estados e, conseqüentemente, na qualidade do desfecho da questão. 


\section{Abstract}

\section{Superficial transboundary waters: the case of the Danube river basin}

In the last decades we have seen the environmental issues being transformed into one of the main challenges for humanity. Their transnational dimension is reached when natural limits do not coincide with political ones, enhancing, therefore, the complexity of the problem. Consequently, topics such as sustainability and environmental security start to acquire an outstanding position in the international agenda, which demands new interpretations of the classic concept of sovereignty.

The concern related to superficial transboundary waters - waters that flow on international river basins - represents a materialization of the challenges mentioned above, mainly because these sources correspond to the greatest share of superficial fresh water and are submitted to severe threats. Among them we can mention: the excessive consumption of limited water supplies, which has been provoking a lack of water crisis; in addition to it there are the inherent antagonisms related to the necessity of sharing these sources, which motivates the competition between distinct national interests. On account of these interests, worries and questions appear referring to the capability the water has to generate or instigate international tensions.

Taking as a starting point the intrinsic relationship between territory and politics, this dissertation identifies the variables linked to the conflictive/cooperative potential of the superficial transboundary waters. Whilst pursuing this task, we have the opportunity to discuss the way the new topics of the international agenda approach this matter.

The analysis of the Danube river basin, as a case study, proves that superficial transboundary waters can spoil the relationships between countries and that geographic and political circumstances are crucial for the definition of the countries interests and, consequently, for the quality of the outcome of this matter. 


\section{Agradecimentos}

Aqueles que já elaboraram - ou acompanharam de perto - uma monografia sabem que o prefixo "mono" deve ser flexibilizado. Na verdade, sem os esforços de muitos, essa seria uma tarefa impossível. Por isso, a gratidão expressa nesse espaço vai muito além de uma mera formalidade.

Em primeiro lugar, agradeço ao meu orientador, professor Dr. Wagner Ribeiro, pelo incentivo e confiança depositada, mesmo nas etapas mais críticas. Também ao professor Dr. André Martin, pelos apontamentos realizados no exame de qualificação e em conversas posteriores.

Sou grato ao programa SYLFF/USP (Ryoichi Sasakawa Young Leaders Fellowship Fund /Universidade de São Paulo) cujo auxílio financeiro, ao longo de 2004, representou uma valiosa contribuição para realização dessa pesquisa.

Agradeço aos meus amigos geógrafos que tiveram influência direta nessa dissertação: Eduardo Campos e Sérgio Moraes. O primeiro pelas nossas discussões de cunho epistemológico ao longo dos últimos anos, além da ajuda na tradução do francês; e o segundo pelo auxílio na interpretação do contencioso central estudado nesse trabalho. Também ao colega geógrafo Marcos Madeira, pela assessoria cartográfica.

O fato de sermos humanos antes de acadêmicos, abre a possibilidade para que contratempos pessoais se transformem em obstáculos tão - ou mais - difíceis quanto aqueles estritamente ligados à pesquisa. Nessas situações, o estímulo e o apoio oferecidos por amigos e colegas são essenciais. Sob esse aspecto, tive muitas pessoas ao meu lado. Além daquelas já citadas, estendo meus agradecimentos sinceros: ao (à) Adenilson, Bene, Aninha, Eduardo Torres (Batata), Luciana Ziglio, Maria Ângela, Squinca e Vau. Também à Juliana, pelo incentivo nas etapas iniciais.

Também sou grato à minha família. Em especial, aos meus país pelos valores e princípios transmitidos ao longo de minha vida, dentre os quais apreendi a importância da educação na formação do indivíduo, sobretudo para aqueles oriundos das classes menos privilegiadas. Não posso me esquecer da Vana e do Sid 
que participaram de algumas etapas operacionais, sempre com eficiência e presteza.

Por fim, esclareço que o questionamento inicial referente ao prefixo "mono", não se estende às eventuais faltas e limitações desse trabalho, estas são de minha única e exclusiva responsabilidade. 


\section{SUMÁRIO}

Introdução

1. Água e Geografia Política $\quad 16$

1.1 A crise mundial da água 16

1.2 Por uma geografia política das águas transfronteiriças superficiais $\quad 29$

2. A ordem ambiental internacional e seus desafios 38

2.1 A construção da ordem ambiental internacional 38

2.2 A segurança ambiental internacional 51

2.3 A questão da soberania nacional 62

3. A geopolítica das águas transfronteiriças superficiais 76

3.1 As bacias hidrográficas transfronteiriças $\quad 77$

3.2 Águas transfronteiriças superficiais: conflito ou cooperação? $\quad 89$

3.3 O compartilhamento das águas transfronteiriças superficiais: um subsistema da ordem ambiental internacional 100

4. As águas transfronteiriças superficiais da Bacia do Rio Danúbio 117

4.1 Caracterização geográfica da bacia 117

4.2 Conflito e cooperação: um balanço 125

4.2.1 As disputas entre Hungria e Eslováquia $\quad 130$

4.3 As variáveis territoriais $\quad 136$

4.4 As variáveis políticas $\quad 147$

4.4.1 O contexto geopolítico 148

4.4.2 A capacidade institucional 152

$4.5 \mathrm{O}$ caso húngaro-eslovaco: um paradigma 157 


\section{LISTA DE GRÁFICOS}

Gráfico 1.1 - Distribuição natural da água 18

Gráfico 1.2 - População Mundial e Consumo de Água 21

Gráfico 3.1 - Eventos em bacias transfronteiriças 92

Gráfico 3.2 - Distribuição de eventos cooperativos 93

Gráfico 3.3 - Distribuição de eventos conflitivos 93

Gráfico 4.1 - Descarga cumulativa do rio Danúbio 121

Gráfico 4.2 - Bacia do rio Danúbio: Total de recursos hídricos renováveis - 2003121

Gráfico 4.3 - Eventos na bacia do rio Danúbio: 1948-2000 126

Gráfico 4.4 - Eventos na bacia do rio Danúbio: 1948-2000 127

Gráfico 4.5 - Conflitos na bacia do rio Danúbio: 1948-2000 129

Gráfico 4.6 - Eventos conflitivos: Hungria-Eslováquia 130

Gráfico 4.7 - Bacia do rio Danúbio: Estresse hídrico - 2003

Gráfico 4.8 - Bacia do rio Danúbio: Disponibilidade hídrica -2003 137

Gráfico 4.9 - Bacia do rio Danúbio: Dependência hídrica externa - 2003

Gráfico 4.10 - Bacia do rio Danúbio: Dependência hidrelétrica -2002 142

LISTA DE MAPAS

Mapa 1.1 - Estresse Hídrico - 1995

Mapa 1.2 - Estresse Hídrico - 2025

Mapa 3.1 - Bacias hidrográficas transfronteiriças (BHT) 79

Mapa 4.1 - Bacia do rio Danúbio: Recursos hídricos renováveis - 2003

Mapa 4.2 - Projeto Gabcikovo-Nagymaros 132 
Mapa 4.3 - Bacia do rio Danúbio: Estresse hídrico - 2003

Mapa 4.4 - Bacia do rio Danúbio: Disponibilidade hídrica - 2003

Mapa 4.5 - Bacia do rio Danúbio: Dependência hídrica externa - 2003

Mapa 4.6 - Bacia do rio Danúbio: Dependência hidrelétrica - 2002

\section{LISTA DE TABELAS}

$\begin{array}{lr}\text { Tabela } 1.1 \text { - Distribuição natural da água } & 18\end{array}$

Tabela 1.2 - Limites fronteiriços definidos por rios internacionais 32

Tabela 1.3 - Limites fronteiriços definidos por elementos orográficos 32

Tabela 3.1 - Maiores rios do globo, segundo descargas médias anuais 78

Tabela 3.2 - As maiores BHT do globo $\quad 80$

Tabela 3.3 - Número de BHT 81

Tabela 3.4 - Número de países, segundo porcentagem do território em BHT 82

Tabela 3.5 - Principais impactos ambientais em sistemas hidrográficos 85

Tabela 3.6 - Principais reuniões internacionais sobre água 102

Tabela 4.1 - Bacia do rio Danúbio: área da bacia nos países 118

Tabela 4.2 - Bacia do rio Danúbio: consumo hídrico 124

Tabela 4.3 - Conflitos na bacia do rio Danúbio: 1948-2000 128

LISTA DE ANEXOS

Anexo I - Escala Bar (Escala de intensidade de eventos) 173 
ATS - Águas Transfronteiriças Superficiais

BAR - Basins at Risk

BHT - Bacias Hidrográficas Transfronteiriças

CCAI - Convenção sobre Cursos d'Água Internacionais

CDI - Comissão de Direito Internacional das Nações Unidas

CED - Comissão Européia para o Danúbio

CEE - Comunidade Econômica Européia

CIJ - Corte Internacional de Justiça

CMA - Conselho Mundial da Água

CNUMAD - Conferência das Nações Unidas para o Meio Ambiente e

Desenvolvimento

ETNs - Empresas Transnacionais

FAO - Organização das Nações Unidas para Agricultura e Alimentação

GEO - Global Environment Outlook

MEA - Millennium Ecosystem Assessment

OAI - Ordem Ambiental Internacional

OCDE - Organização para a Cooperação e Desenvolvimento Econômico

OIGs - Organizações Internacionais Governamentais

OMM - Organização Mundial de Meteorologia

ONGs - Organizações Não Governamentais

ONU - Organização das Nações Unidas

PNUMA - Programa das Nações Unidas para o Meio Ambiente

TFDD - Transboundary Freshwater Dispute Database

UNECE - Comissão Econômica das Nações Unidas para a Europa

UNESCO - Organização das Nações Unidas para Educação, Ciência e Cultura WWDR - World Water Development Report 


\section{Introdução}

Acredito que seja conveniente esclarecer ao leitor desta dissertação quais foram os caminhos que me conduziram a pesquisar o compartilhamento das águas transfronteiriças por meio das bases teórico-metodológicas da geografia política.

Ao refletir sobre tais caminhos, encontrei um percurso mais longo do que eu próprio poderia supor, iniciado antes mesmo de meu ingresso nesta Universidade.

Certamente suas raízes estão no momento em que terminei o Ensino Médio, então $2^{\circ}$ grau, e optei em cursar geografia no ensino superior. Na verdade, essa escolha foi fruto do fascínio que as questões "geopolíticas", apresentadas no curso pré-vestibular, exerciam sobre mim. Definitivamente, para aquele vestibulando, estudar as relações de poder entre os Estados era algo extremamente complexo e instigante e a geografia era a ciência mais indicada para compreendermos as disputas territoriais, étnicas, econômicas e políticas da atualidade.

Ao chegar ao curso de Geografia desta casa, em 1993, tive uma relativa decepção e uma grata surpresa. A primeira estava no fato de não existir tantas disciplinas de "geopolítica", quanto aquele jovem gostaria. A segunda, que superou em muito a primeira, mostrou-me que a ciência geográfica era muito mais fascinante e ampla que as aulas de "geopolítica" dos cursos pré-vestibulares. Aprendi que suas categorias centrais - território, espaço, região, paisagem etc - representavam objetos dos mais variados e instigantes estudos nos quais poderia focar questões urbanas, rurais, econômicas, políticas, entre tantas outras.

Também passei a acreditar que tais estudos representavam importantes subsídios para a intervenção na realidade e, por que não, contribuições para alcançarmos um mundo melhor e mais justo. Utopia? Idealismo? Mais de uma década depois, ainda não tenho a reposta definitiva, porém continuo motivado por essa crença. $O$ fato é que, ao longo desse processo de descoberta, minha identificação com a Geografia tornou-se irreversível. 
Entre muitos cursos marcantes de minha graduação, merece citação a disciplina Geografia dos Recursos Naturais, ministrado pelo Prof. Dr. Wagner Ribeiro. A partir dela, passei a compreender a problemática ambiental como uma síntese dos mais variados fatores - naturais, sociais, econômicos e políticos - que incidem dialeticamente na produção do espaço geográfico e resultam em desarranjos nos sistemas naturais nas mais diversas escalas geográficas, da local à global.

Decidi, então, que meu Trabalho de Graduação Individual (TGl) abordaria a questão ambiental, faltava definir o tema e a área de estudo. Dúvidas que foram superadas após a realização da disciplina de Biogeografia, ministrada pelo saudoso Prof. Dr. Felisberto Cavalheiro. Com o objetivo de realizar o trabalho final dessa disciplina, passei a estudar os mananciais do Sistema Cantareira, os principais responsáveis pelo abastecimento da Região Metropolitana de São Paulo (RMSP), enfatizando as ameaças à qualidade e à quantidade de suas águas.

Assim a questão dos recursos hídricos tornou-se o foco de minhas inquietações acadêmicas, passei a entendê-la como uma importante materialização da questão ambiental, repleta de complexidade, desafios e relevância social. Em meu TGI, desenvolvido em 1998, sob orientação do Prof. Dr. Wagner Ribeiro, aprofundei os estudos sobre o abastecimento da RMSP, destacando a mudança da Legislação de Proteção pertinente e utilizando um importante manancial como estudo de caso ${ }^{1}$.

Ao retornar à academia com o intuito de ingressar na pós-graduação, tomei conhecimento da atual linha de pesquisa do Prof. Dr. Wagner Ribeiro: geografia política e meio ambiente. Para minha satisfação, ela possibilitava a realização de um antigo desejo - aquele de desenvolver estudos geopolíticos mais aprofundados associado à interpretação da questão ambiental na sua dimensão transnacional. Ainda melhor, o objeto ao qual dediquei minha atenção durante o final da graduação - recursos hídricos - permeava as principais discussões dentro da concepção teórico-metodológica que me era apresentada.

\footnotetext{
${ }^{1}$ SANTOS, Sinval Neves. Mananciais na RMSP: Represa Paiva Castro. TGI /DG/FFLCH/ USP, 1998.
} 
Desde então, minhas pesquisas evoluíram no sentido de sistematizar a importância e pertinência desse objeto dentro dessa linha de pesquisa e, conseqüentemente, dentro da geografia. A dissertação que ora apresento resulta dessa iniciativa.

Minha primeira e principal inquietação relacionada à questão dos recursos hídricos em escala internacional está ligada ao seu teor conflitivo. Afinal, a água será o recurso mais disputado do século que se inicia? Haverá guerras pela água?

O presente trabalho busca contribuir para a elucidação de tais indagações, nele será abordada uma das dimensões da ampla e complexa problemática dos recursos hídricos mundiais: a questão das águas transfronteiriças superficiais (ATS). Seu objetivo central é identificar os fatores que influenciam a capacidade das disputas e concorrências por águas que circulam em rios internacionais gerar, ou potencializar, conflitos internacionais.

Para essa tarefa foi utilizado um amplo leque de fontes, que abrange desde autores que se dedicaram ao tema até relatórios de organismos internacionais. Dentre elas merecem destaque os trabalhos do geógrafo Wagner Ribeiro, nos quais ele identifica a edificação de uma ordem ambiental internacional (RIBEIRO, 2001) e considera as tentativas de regulamentação dos recursos hídricos como um subsistema dessa ordem (RIBEIRO, 2004).

Outra fonte de dados essencial para o presente trabalho foi o Transboundary Freshwater Dispute Database (TFDD), elaborado por especialistas da Oregon State University. Seus registros proporcionaram as bases empírico-estatísticas para avaliação dos eventos interestatais relacionados ao compartilhamento das ATS, tanto no mundo quanto na bacia hidrográfica escolhida para estudo de caso, a bacia do rio Danúbio.

No primeiro capítulo da dissertação, o leitor encontrará uma análise da distribuição e consumo da água doce em escala mundial, nele fica ressaltado que a crise de escassez observada atualmente possui fortes relações com o tema central de nossa pesquisa. Ainda nesse capítulo, o leitor encontrará as referências que legitimam a abordagem da geografia política sobre o tema dos recursos hídricos. 
No segundo capítulo, será apresentada a principal premissa teórica desse trabalho, ou seja, o pressuposto de que acompanhamos a construção de uma ordem ambiental internacional. Após explicitar a lógica e os principais atores desse processo, são discutidos dois temas centrais à essa realidade. Um deles, a segurança ambiental internacional, trata das preocupações em torno dos conflitos ambientais; o outro, soberania nacional, analisará os novos desafios trazidos pela questão ambiental ao poder dos Estados dentro de seus limites fronteiriços.

O capítulo três avaliará como as dificuldades apresentadas no capítulo anterior incidem sobre a questão das ATS. Após a apresentação da distribuição global das águas doces superficiais sob tais circunstâncias, será demonstrado como os limites naturais e a dinâmica das bacias hidrográficas transfronteiriças trazem implicações à concepção clássica de soberania e que a posição geográfica representa uma variável vital na definição dos interesses dos Estados envolvidos.

Quanto às implicações das disputas por recursos hídricos na segurança ambiental internacional, será exposto um balanço das relações interestatais conflitivas e cooperativas relativas as ATS, ocorridas na segunda metade do século passado. A partir desse balanço, ficará constatado que apesar da prevalência de atitudes de cooperação, não é possível descartar a hipótese de que disputas por tais recursos podem motivar conflitos entre Estados. A partir da análise da bibliografia pertinente, serão apontadas as variáveis - territoriais e políticas - relacionadas ao potencial conflitivo/cooperativo da questão.

Ainda no capitulo três, serão discutidas as negociações referentes à regulamentação do compartilhamento das ATS. Defenderemos que tais iniciativas constituem um subsistema interno - ainda em construção - da ordem ambiental internacional e que a análise de seu desenvolvimento aponta para uma combinação do realismo político com a teoria da interdependência.

O quarto e derradeiro capítulo, aborda as interações interestatais ligadas as águas transfronteiriças da bacia do rio Danúbio, proporcionando a análise dos processos e das questões discutidas nos capítulos anteriores a partir de um caso concreto. Inicialmente será avaliada distribuição espacial e temporal dos eventos 
conflitivos e cooperativos verificados na segunda metade do século XX. Essa tarefa evidenciará uma clara concentração de conflitos envolvendo a Eslováquia - então Tchecoslováquia - e a Hungria, ocorridos no período pós guerra fria. No intuito de identificar os fatores conflitivos relacionados, será exposto um diagnóstico das variáveis territoriais e das variáveis políticas existentes na bacia.

Esse trabalho foi alimentado pela crença de que a avaliação dos fatores ligados ao potencial conflitivo das ATS permite identificar bacias hidrográficas sob risco na atualidade, além de subsidiar a construção de cenários futuros, contribuindo, assim, para criação de mecanismos capazes de atuarem na mitigação e prevenção de conflitos. 


\section{Capítulo 1 - Água e Geografia Política}

Iniciaremos nosso trabalho apresentando a água doce como um recurso essencial à sociedade e avaliando sua distribuição geográfica na escala mundial. Após analisar os principais aspectos da crise de escassez observada atualmente, demonstraremos as relações desta crise com nosso tema central: o potencial conflitivo que envolve as águas transfronteiriças superficiais.

Também enfatizaremos que tal problemática será abordada a partir de suas variáveis geográficas e políticas e que esta dissertação pretende trazer uma contribuição para o arcabouço teórico que esta sendo construído a partir dos trabalhos do geógrafo Wagner Ribeiro (2001 e 2004).

Considerando a estrutura dedutiva de nossa dissertação, este capítulo será essencial para contextualizar o leitor perante aos capítulos seguintes.

\subsection{A crise da água}

São notórias as implicações que a escassez de água impõe aos seres vivos, aos ecossistemas e obviamente às atividades humanas em geral. Nos recentes encontros promovidos pela ONU (Organização das Nações Unidas) em relação ao tema, tem se tornado cada vez mais consensual o entendimento da água doce como um recurso finito e vulnerável a diversas ações da sociedade. Vulnerável em razão de formas de uso que comprometem o seu ciclo natural e que colocam a perspectiva de crise de escassez desse importante recurso. Ademais, torna-se cada vez mais evidente que essa crise se processa tanto em termos quantitativos quanto qualitativos.

O geógrafo Claude Raffestin (1993) nos alerta para a necessária diferenciação entre os conceitos de matéria e recurso. Segundo ele, matéria ou substância é um "dado", pois preexiste a toda ação humana, sendo, portanto, um 
resultado de forças que interagiram ao longo do tempo sem a contribuição ou intervenção da sociedade (RAFFESTIN, 1993:225). A transformação da matéria ou substância num recurso depende da combinação entre o trabalho humano e as intenções que envolvem a relação entre a sociedade e a matéria (RAFFESTIN, 1993:225).

O cientista político Raymond Aron (2002) apresenta uma definição de recursos muito semelhante à de Raffestin:

\begin{abstract}
Entendo por recursos o conjunto de meios materiais de que dispõem as coletividades para assegurar sua subsistência. (...) [os homens] são sujeitos da atividade que transforma as coisas em bens; quer dizer que servem para satisfazer as necessidades ou desejos. $O$ conceito de recurso cobre um campo muito grande, desde o solo e 0 subsolo até os alimentos e produtos manufaturados (ARON, 2002:325).
\end{abstract}

Fazemos essas referências para esclarecer ao nosso leitor que neste trabalho a água será entendida com um recurso, pois cada vez mais ela se apresenta como um elemento vital para a reprodução do capital e para o desenvolvimento das estratégias estatais. Sob esta abordagem, além da análise da distribuição natural deste recurso, torna-se essencial a avaliação do modo como as principais transformações vivenciadas pela humanidade no século XX alteraram as demandas pela água.

A distribuição deste recurso segundo seus principais reservatórios no planeta Terra é bastante desigual. Ela está detalhada na TABELA 1.1 e ilustrada de forma simplificada e adaptada no GRÁFICO 1.1.

Como podemos constatar, dos 1.386 milhões de $\mathrm{km}^{3}$ de água do Globo, $96,5 \%$ são salgados. Os cerca de 35 milhões de água doce equivalem a 2,5\% do total de água no planeta. Porém, $68,7 \%$ se encontram em estado sólido e se localizam em áreas de difícil acesso à exploração, como a Antártica e cumes nevados de altas montanhas. Os $30,3 \%$ restantes se encontram distribuídos entre subsolo $(30,1 \%)$, rios, pântanos entre outros reservatórios. 
Tabela 1.1: Distribuição natural da água*

\begin{tabular}{|l|c|c|c|}
\hline & $\begin{array}{c}\text { Quantidade } \\
\left(1000 \mathrm{~km}^{3}\right)\end{array}$ & $\begin{array}{c}\% \text { na } \\
\text { hidrosfera }\end{array}$ & $\begin{array}{c}\text { \% de } \\
\text { água doce }\end{array}$ \\
\hline Oceanos & 1.338 .000 & 96,5 & \\
\hline Subsolo & 23.400 & 1,7 & \\
\hline Umidade do solo & 10.530 & 0,76 & 30,1 \\
\hline \hline Água doce no subsolo & 16,5 & 0,0001 & 0,05 \\
\hline Glaciares, calotas polares e picos nevados & 24.064 & 1,74 & 68,7 \\
\hline Lagos - água doce & 91,0 & 0,007 & 0,26 \\
\hline Lagos - água salgada & 85,4 & 0,006 & \\
\hline Pântanos & 11,5 & 0,0008 & 0,03 \\
\hline Rios & 2,12 & 0,0002 & 0,006 \\
\hline Biomassa & 1,12 & 0,0001 & 0,003 \\
\hline Vapor d'água & 12,9 & 0,001 & 0,04 \\
\hline Volume total & 1.386 .000 & 100 & \\
\hline Total - água doce & $35.029,2$ & 2,53 & 100 \\
\hline
\end{tabular}

${ }^{*}$ Os totais indicados não equivalem à soma das partes devido aos diversos arredondamentos sofridos pelos valores. Fonte: Unesco, 2003:68.

Gráfico 1.1: Distribuição natural da água

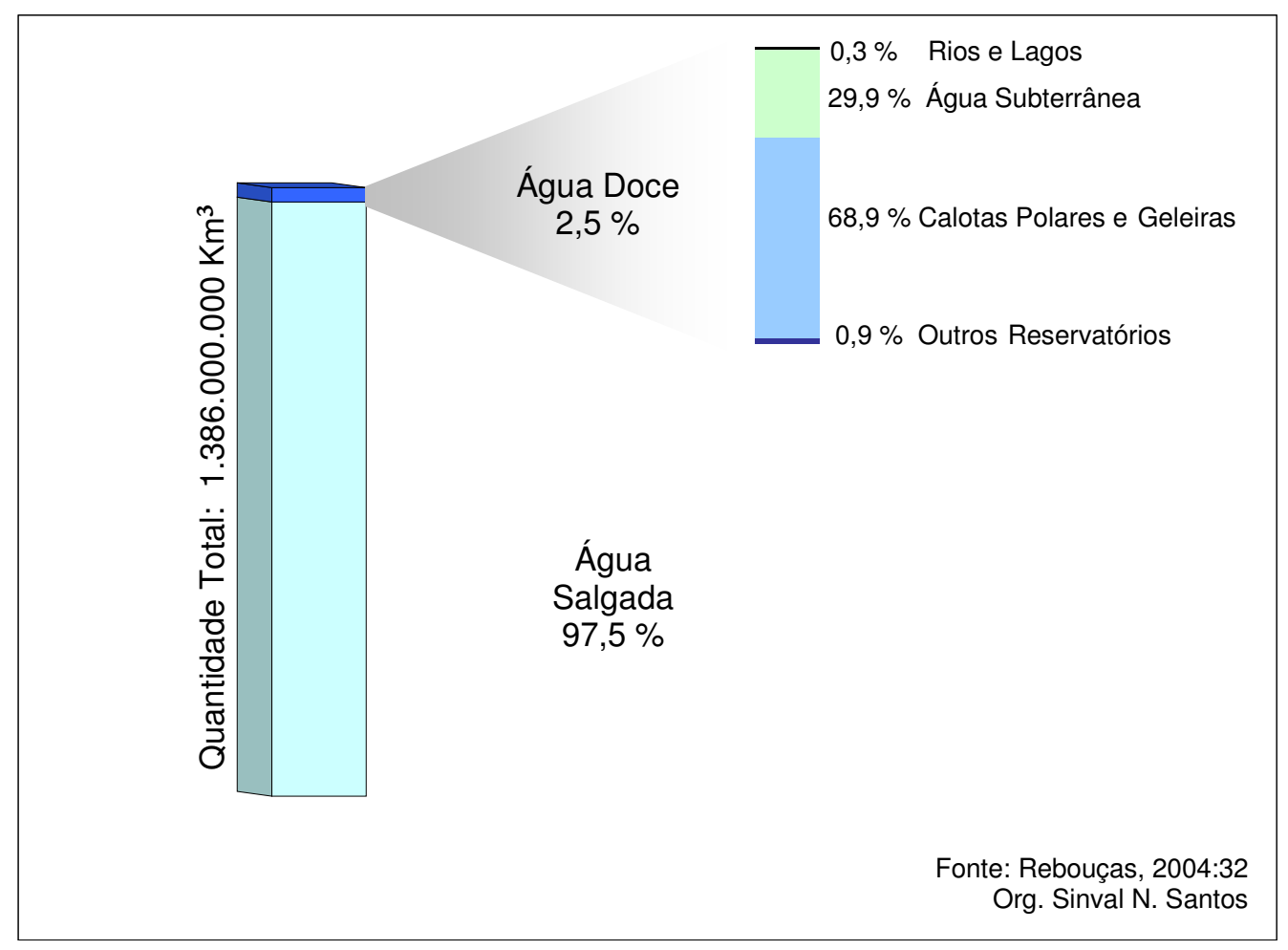


A análise da distribuição natural da água demonstra que as parcelas de maior utilidade e acessibilidade à espécie humana - aquelas que denominaremos águas superficiais $^{2}$ - representam uma mínima fração do total da água doce do globo. Afinal, apenas $0,26 \%$ desses recursos se encontram em lagos de água doce, enquanto somente $0,006 \%$ circulam pelas calhas dos rios.

Considerando que vivemos em um "mundo salgado" e também ponderando as dificuldades e custos inerentes a exploração da água subterrânea e da água congelada, avaliamos a água como um recurso abundante, porém de acesso limitado. Fato que potencializa a relevância das águas superficiais e, conseqüentemente, de estudos sobre a dinâmica, as ameaças e as disputas que envolvem essa parcela dos recursos hídricos.

Dada sua grande acessibilidade, a importância das águas superficiais para as sociedades contemporâneas manifesta-se nos mais diversos usos e funções:

- na dessedentação humana e de rebanhos;

- na produção de alimentos;

- na manutenção da saúde e da dignidade humana, através da higiene e do saneamento;

- na indústria, empregada sob diversas formas;

- na geração de energia elétrica;

- como vias para meios de transporte;

- na conservação e preservação de ecossistemas;

- além de outras atividades inerentes à vida moderna, como o lazer.

Se por um lado as águas dos rios e lagos doces representam aquelas de mais fácil acesso à humanidade e com maior diversidade de usos, tais reservatórios se apresentam como os mais vulneráveis no tocante a quantidade e qualidade de seus estoques. As transformações da sociedade, intensificadas a partir do século $\mathrm{XX}$, geram um cenário de demandas e degradações crescentes, frente a uma oferta

\footnotetext{
${ }^{2}$ Nesse trabalho o termo "águas superficiais" definirá os recursos de água doce que escoam sobre as bacias hidrográficas e se concentram em rios, lagos e represas. Aldo Rebouças utiliza a expressão: blue water flow, ao classificar essas parcelas dos recursos hídricos (REBOUÇAS, 2004:28).
} 
limitada. Este quadro é agravado pelo fato destes recursos não estarem uniformemente distribuídos pelo planeta.

Atualmente são muitos especialistas que afirmam que a escassez relativa da água será uma das principais ameaças para a paz e prosperidade em um futuro próximo. Além disso, já é praticamente consensual o entendimento de que a sociedade contemporânea presencia uma crise da água em escala global.

Koichiro Matsuura, Diretor Geral da Organização das Nações Unidas para Educação, Ciência e Cultura (UNESCO), afirma que de "todas as crises sociais e naturais que a humanidade tem enfrentado, a da água é a que mais afeta a sua sobrevivência no Planeta Terra" (UNESCO/PHI, 2003).

O Dicionário de Política de Bobbio, Metteucci e Pasquino (2004) define crise como: um processo no qual o funcionamento de um sistema é colocado em questão, e cuja ocorrência determina alterações quantitativas e qualitativas no funcionamento ou continuidade desse sistema. Ainda segundo esta concepção, pode-se determinar três momentos de uma crise, de modo a termos condições para a sua compreensão:

(...) a fase precedente ao momento em que se inicia a Crise, a fase da Crise propriamente dita e, por fim, a fase depois que a Crise passou e o sistema tomou um certo 'módulo' de funcionamento que não se identifica com o que precedeu a Crise (BOBBIO; METTEUCCI; PASQUINO, 2004:303).

Tendo como pressuposto a formulação acima de crise, torna-se verossímil a afirmação de que atualmente estamos no momento que precede a crise dos recursos hídricos em escala mundial. Isso se considerarmos que o sistema produtivo global ainda não entrou em colapso e que a humanidade ainda não está ameaçada de extinção por conta da escassez de água potável. Contudo, há de se enfatizar que ao contrário de muitas crises às quais o mundo contemporâneo esteve submetido, a iminente crise da água dispõe de um consenso maior de materialidade bem como de melhores condições para sua previsibilidade, em que pese as imprecisões inerentes a qualquer tentativa de previsão de cenários. 
O World Water Development Report ${ }^{3}$ (WWDR) ao traçar cenários para 2050, apontou que faltará água para 2 bilhões de pessoas em 48 países, na visão otimista; e para 7 bilhões em 60 países, no prognóstico pessimista (UNESCO, 2003).

Porém, para muitas pessoas a crise já é uma realidade concreta. Segundo o mesmo relatório, cerca de 1,1 bilhão de habitantes sofrem atualmente para suprir suas necessidades básicas, enquanto 2,5 bilhões de pessoas não têm acesso a serviços de saneamento básico (UNESCO, 2003:10).

De acordo com o Global Environment Outlook 3 (GEO-3), em meados da década de 1990, cerca de 80 países - que abrigavam 40 por cento da população mundial - já sofriam de graves problemas de escassez de água (UNEP, 2002-a:150).

As causas dessa crise são múltiplas e complexas. Apesar disso, análises simplistas apontam como principal fator da crise da água o crescimento populacional. Para ponderarmos esta assertiva se torna necessária a análise do gráfico a seguir.

\section{GRÁFICO 1.2:}

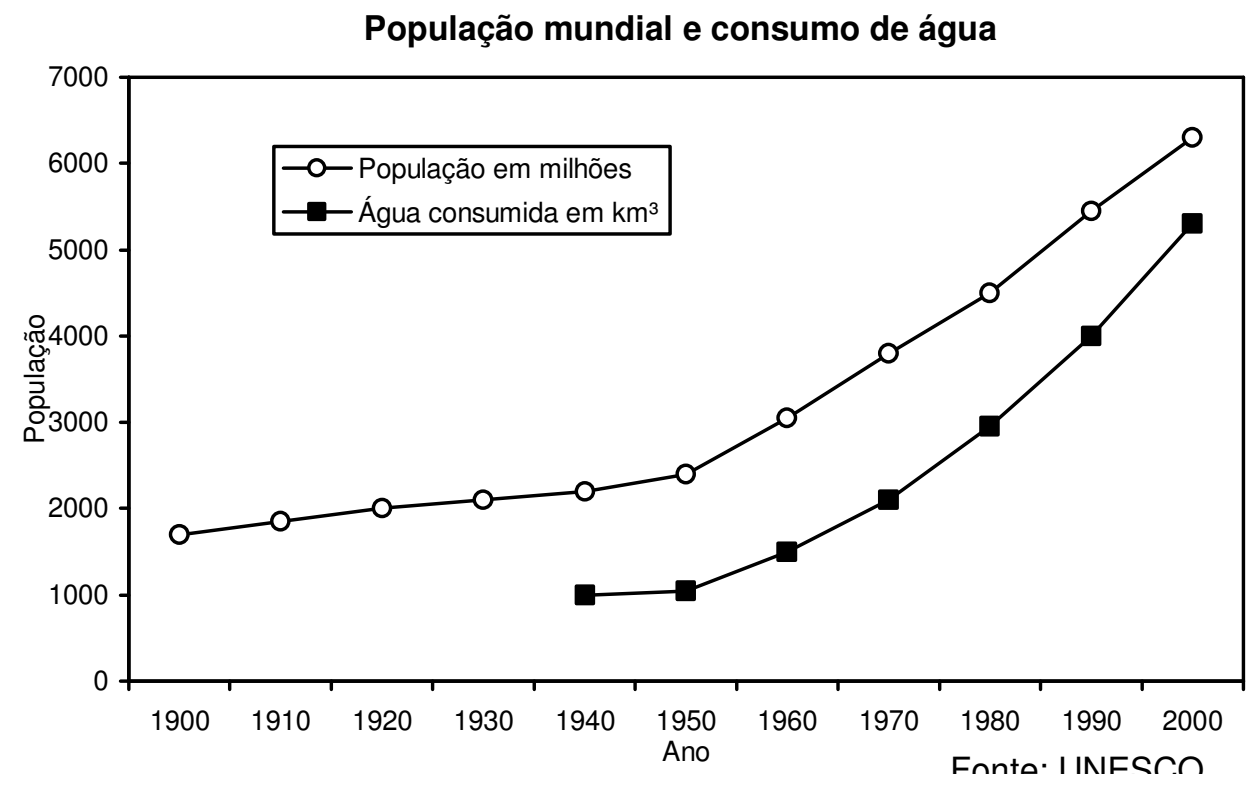

\footnotetext{
${ }^{3}$ Esse relatório - também denominado Water for People, Water for Life - foi apresentado no $3^{\circ}$. Fórum Mundial da Água, ocorrido em Kyoto, em 2003. Ele representa a visão mais completa e atualizada sobre o estado em que se encontram os recursos hídricos do globo. Para sua elaboração foram mobilizadas 23 agências ONU sob a coordenação da UNESCO e do Departamento de Assuntos Econômicos e Sociais das Nações Unidas.
} 
O GRÁFICO 1.2 demonstra que o consumo de água cresceu mais que a população nos últimos 50 anos. Em 1950, a população do planeta era menor que 3 bilhões de habitantes, enquanto o consumo hídrico estava perto de $1.200 \mathrm{Km}^{3}$. Já no ano 2000, a população dobrou (chegando a pouco mais de 6 bilhões), porém o consumo de água quadruplicou ao atingir os $5.200 \mathrm{Km}^{3}$. Esses dados são suficientes para evidenciar que o aumento populacional é apenas um dos fatores ligados a crise da água, mas não seu principal causador.

A Millennium Ecosystem Assessment (MEA) ${ }^{4}$ constatou que a redução no nível das águas de rios e lagos para os fins de irrigação, consumo doméstico e industrial dobrou nos últimos 40 anos; além disso, os seres humanos usam atualmente de $40 \%$ a $50 \%$ da água doce corrente à qual a maior parte da população tem acesso (MEA, 2005).

O geólogo Aldo Rebouças (2004) aponta o desperdício, a degradação e a deficiência (ou ausência) de gerenciamento adequado como principais fatores da atual crise da água. Em seu entendimento a solução passa pelo desenvolvimento e aplicação de políticas públicas e tecnologias que proporcionem maior economia e gestão integrada da "gota d'água disponível".

Para o geógrafo Wagner Ribeiro (2004) a crise da água é resultado de diversos fatores: escassez pontual, consumo exagerado e transformação da água em mercadoria na escala internacional. Segundo ele não haverá falta de água se essas dificuldades forem superadas. E ainda enfatiza que "para entender a crise é preciso conhecer a sociedade contemporânea hegemônica, baseada no consumo" (RIBEIRO, 2004:4).

O WWDR (UNESCO, 2003) apresenta uma avaliação sobre as diversas mudanças da sociedade contemporânea que afetam a qualidade e quantidade da água. Estas mudanças estariam relacionadas:

(a) às mudanças geopolíticas;

(b) ao aumento populacional;

(c) à demanda agrícola;

\footnotetext{
${ }^{4}$ A Avaliação Ecossistêmica do Milênio (MEA) foi solicitada pelo Secretário Geral da ONU, Kofi Annan, em 2000. Iniciada em 2001, essa tarefa envolveu mais de 1360 especialistas de 95 países e muitas agências da ONU, sob coordenação do PNUMA.
} 
(d) à energia;

(e) à urbanização;

(f) ao crescimento econômico e social;

(g) à globalização;

(h) às mudanças tecnológicas;

(i) ao estilo de vida;

(j) ao turismo e lazer; e

(h) às mudanças globais.

Em função da multiplicidade de fatores relacionados à crise da água, entendemos que a vulnerabilidade desse recurso traz implicações em três dimensões da concepção de desenvolvimento da sociedade: social, econômica e ambiental.

A perspectiva social de desenvolvimento precisa considerar a água como recurso essencial. Lembramos que o acesso à água potável resulta diretamente nos dados que compõem o Índice de Desenvolvimento Humano, já que condições adequadas de abastecimento e saneamento promovem índices de doenças e mortalidade muito menores. Por isso nos diversos documentos das Nações Unidas relacionados à promoção do desenvolvimento, questões pertinentes ao acesso a água são consideradas nas propostas de combate à pobreza e superação do subdesenvolvimento.

$\mathrm{Na}$ dimensão econômica, a água é um recurso essencial para atividades como agropecuária, pesca, transporte e indústria. O comprometimento desse recurso conduz inevitavelmente a problemas econômicos que afetam tanto a produção quanto à circulação de bens e serviços, cujos impactos podem ser os mais variados possíveis.

Em termos quantitativos estima-se a atual demanda de água doce mundial em cerca de $5.000 \mathrm{Km} 3 /$ ano, divididos entre usos: agrícola (70\%), industrial $(20 \%)$ e doméstico (10\%) (REBOUÇAS, 2004: 96).

A agropecuária consome cada vez mais volumes consideráveis de água, o que nem sempre se compatibiliza com a capacidade de reposição desse recurso. 
Dentre as muitas utilidades que a água tem na agricultura, a irrigação sem dúvida é a que mais evidentemente se mostra como dependente e sujeita à oferta.

A indústria é outra importante consumidora de água. Por isso a crescente fabricação de variados produtos representa mais um fator de pressão. A indústria de papel e a siderurgia são os exemplos notórios de setores industriais que utilizam grandes quantidades de água e que também emitem consideráveis quantidades de poluentes de diversas naturezas. Indiretamente, temos a indústria do alumínio que ao exigir grandes quantidades de energia elétrica resulta em impactos relevantes sobre os recursos hídricos, sobretudo fluviais.

A despeito da produção de hidreletricidade não demandar diretamente grande consumo de água, a evaporação dos reservatórios que essa fonte de energia exige constitui um importante fator de consumo, ainda que indireto.

Segundo a MEA (2005), entre 1960 e 2000, a capacidade de armazenamento em reservatórios quadruplicou. Como resultado, estima-se que a quantidade de água armazenada em grandes represas seja de três a seis vezes a quantidade que flui naturalmente nos rios naturais (excluindo-se lagos naturais).

Ainda que incipiente em termos globais, a recreação e o turismo também são atividades que devem ser associadas ao gerenciamento dos recursos hídricos, para que elas não se transformem em ameaças a qualidade dos mananciais.

De uma forma geral, a busca por água em rios, lagos e aqüíferos tem atendido à necessidade do processo de produção crescente na lógica capitalista. Admitindo-se a água como um recurso finito, cuja oferta em variadas formas tem limitações, a lógica de um consumo crescente e dispendioso é obviamente insustentável. O comprometimento de mananciais superficiais e o esgotamento de reservas subterrâneas são as conseqüências de ações humanas que colocam em questão a continuidade das atuais formas de uso econômico de água.

A dimensão ambiental da concepção de desenvolvimento está intrinsecamente ligada às demais. Considerando-se que o equilíbrio da natureza é fundamental para a reprodução da base material da vida (e do capital) não há desenvolvimento duradouro sem equilíbrio ambiental de longo prazo. Assim 
podemos entender como as mais nobres funções da água, aquelas que são vitais na manutenção de ecossistemas e da biodiversidade.

Como sabemos, muitas atividades humanas provocam grande impacto ambiental sobre os ecossistemas de forma indireta, sem necessariamente se utilizar desses ecossistemas para suas finalidades. A contaminação decorrente do uso indiscriminado de agrotóxicos, a eliminação de resíduos de atividades de mineração ou indústria, assim como a navegação intensa, são algumas dessas atividades que causam significativos impactos ambientais utilizando as águas alteradas como principal vetor de desequilíbrio.

O WWDR (UNESCO, 2003) defende que a idéia da água como um recurso inesgotável deve ser superada, uma vez que temos evidências de sua escassez em diversos lugares do mundo e de que a sua provável escassez em maior escala geográfica exige novas posturas de usos e maiores responsabilidades de todos os interessados na manutenção da vida. Contudo, o mesmo relatório aponta para a desigualdade de impactos e responsabilidades sobre o problema.

Quanto maior a renda e os índices de urbanização da população de uma região maior será o consumo de água e, conseqüentemente, os impactos qualitativos e quantitativos aos estoques desses recursos. Por outro lado, são nas regiões rurais mais pobres que encontramos as maiores deficiências nos sistema de abastecimento de água potável.

Em conseqüência, as assimetrias das relações Norte-Sul também são manifestadas em relação ao uso da água. Uma criança num país desenvolvido consome entre 30 e 50 vezes mais água do que uma criança de um país subdesenvolvido. Encontramos, nos países do Norte, um maior acesso à água potável por meio de sistemas de tratamento e distribuição, há muito tempo construídos; além disso, nesses países é mais freqüente a prática do desperdício, que evidentemente contribui para a maior perda de água. Também os padrões de produção e consumo no mundo desenvolvido intensificam a desigualdade que repercute nas formas de uso desse importante recurso (UNESCO, 2003).

Ribeiro também enfatiza o consumo desigual da água ao demonstrar que: os países da Organização para a Cooperação e Desenvolvimento Econômico (OCDE) 
que somam $15 \%$ da população mundial, utilizam $27 \%$ dos recursos hídricos da Terra; quantidade que supera a soma do uso domiciliar no resto do mundo (RIBEIRO, 2004:212).

Os mapas 1.1 e 1.2, construídos a partir de dados divulgados no GEO-2000 (UNEP, 1999), ilustram uma das formas de mensuração do consumo de água ${ }^{5}$ : o estresse hídrico, este indicador pondera a disponibilidade e o uso da água por países. A partir dos mapas, constatamos que já são muitas as regiões do globo com deficiência hídrica e que o cenário se tornará sensivelmente pior em 2025.

O MAPA 1.2 demonstra que na década de 1990 o número de países em estresse hídrico elevado (mais de 40\%) já era significativo: Tunísia, Argélia e Egito, na África; praticamente todos os países do Oriente Médio e o Paquistão, na Ásia.

A MEA alerta para o fato de que atualmente em algumas regiões, como 0 Oriente Médio e o Norte da África, o homem usa 120\% dos recursos renováveis devido ao uso de água subterrânea, que não pode ser renovada em curto prazo (MEA, 2005).

A partir do MAPA 1.2 constatamos que a faixa de países em estresse hídrico elevado irá ampliar-se por todo o Norte da África, passando pelo Oriente Médio para finalizar na Índia. Entre os países que devem estar em estresse hídrico considerado como médio alto (entre 20 e 40\%), estão os principais pólos dinâmicos do planeta: EUA e China, além de expressiva parcela dos países europeus.

Portanto, em que pese as divergências sobre o estágio e a escala geográfica da crise da água, comprova-se que ela já é uma realidade e que a escassez relativa, já manifestada em escala regional, tende a se agravar e ampliar sua abrangência num futuro próximo.

O essencial para o nosso estudo é que o acirramento dessa crise de escassez tende a aumentar as disputas pela água e, principalmente, o potencial conflitivo de questões que envolvem o compartilhamento das águas transfronteiriças superficiais. Já que estas representam as parcelas de água doce mais acessíveis e ameaçadas.

\footnotetext{
${ }^{5}$ Para uma análise detalhada sobre as várias maneiras de mensurar a relação demanda/consumo sobre recursos hídricos em uma unidade territorial ver RIBEIRO, 2004:110-125.
} 


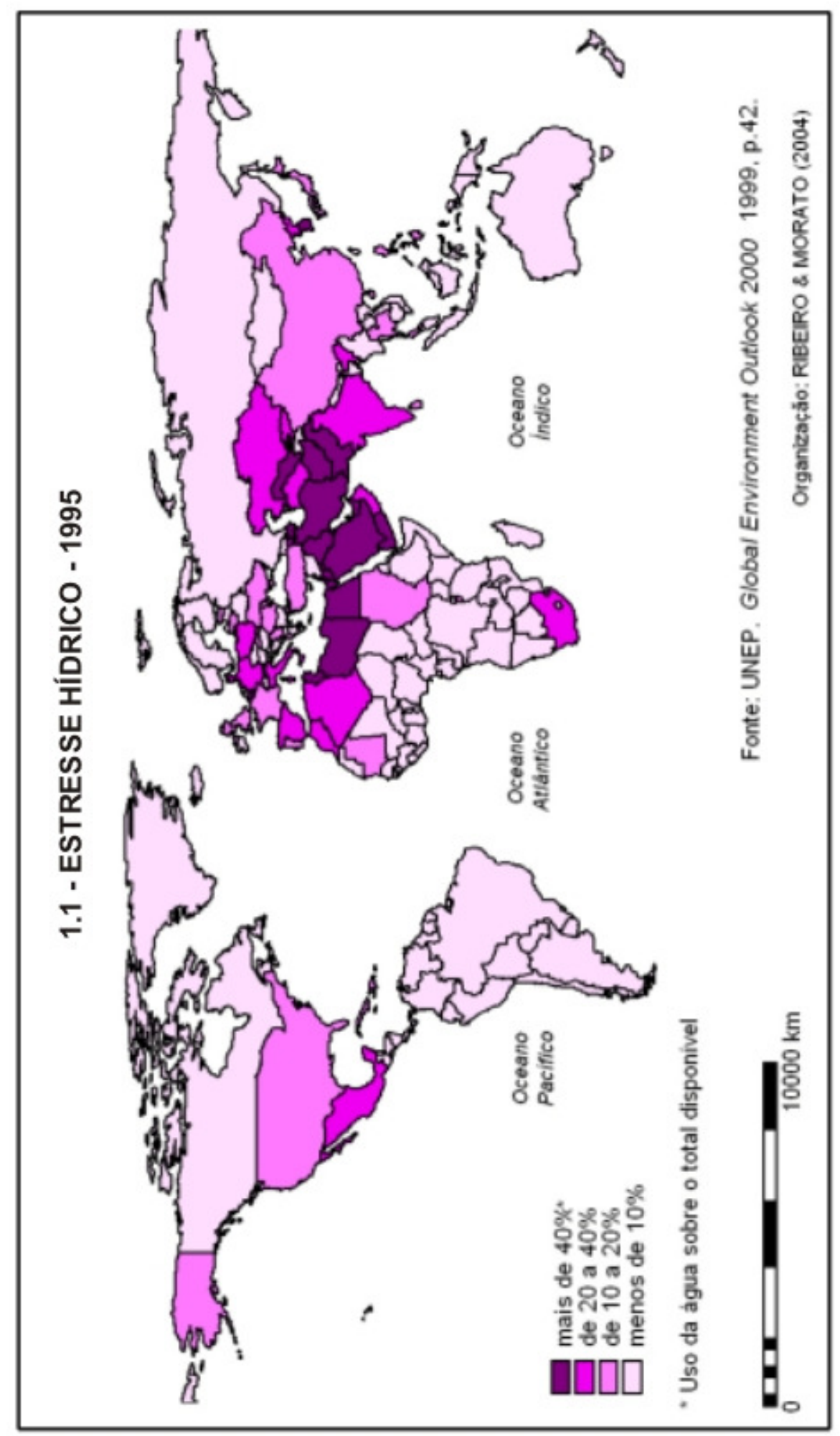




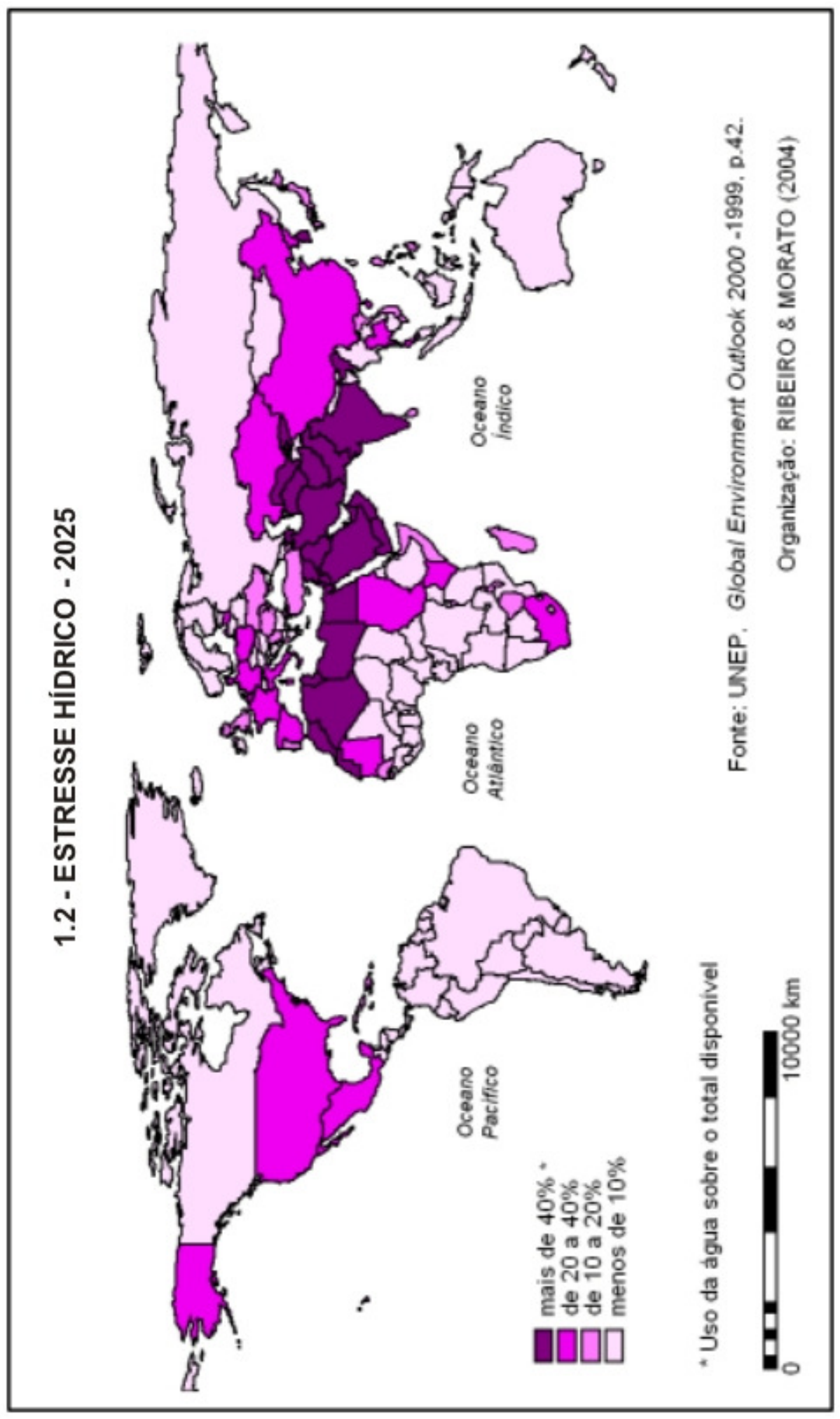


Como veremos mais detidamente, não são poucos os especialistas preocupados com essa relação escassez/conflito. Entre eles, Steve Lonergan, Diretor $^{6}$ do Programa das Nações Unidas para o Meio Ambiente (PNUMA), reconhece que "a tensão sobre a água aumentará, à medida que a escassez aumente". Para ele, a degradação do meio ambiente e o esgotamento dos recursos são "ameaças brandas" à segurança comum (PNUMA, 2005:27).

\subsection{Por uma geografia política das águas transfronteiriças superficiais}

Mesmo considerando a amplitude e complexidade que envolvem a questão da água no mundo contemporâneo, nossa dissertação abordará apenas uma das dimensões da temática: o compartilhamento das águas superficiais. Nossa opção se deu, em grande parte, devido à sua relevância à humanidade, já que essas águas representam os mananciais mais acessíveis e escassos, em relação ao total de água doce do Globo.

Mais precisamente, enfocaremos a questão do compartilhamento das águas superficiais em sua escala internacional.

A maior parcela das águas superficiais do globo escoa sobre um total de 263 bacias hidrográficas transfronteiriças - ou seja, bacias compartilhadas entre dois ou mais países - e serão aqui denominadas: águas transfronteiriças superficiais(ATS).

Demonstraremos, ao longo do trabalho, os inúmeros desafios que envolvem as águas superficiais definidas por essa circunstância político-territorial. Adiantamos, desde já, que a matriz destes desafios está no fato dos limites e dinâmicas naturais não coincidirem, em grande parte dos casos, com os limites e dinâmicas políticas.

A dinâmica natural das bacias hidrográficas transfronteiriças obriga uma relação política direta entre Estados que devem levar em conta seus interesses nacionais no uso da água. Em algumas dessas situações, a necessidade de compartilhamento pode evoluir para interações cooperativas, sem grandes disputas.

\footnotetext{
${ }^{6}$ Diretor do Departamento de Avaliação e Alerta Antecipado.
} 
Já em outros casos, os interesses nacionais em jogo podem acirrar posições, levando a questão a um alto grau de confronto internacional, incluindo a hipótese de eclosão de um conflito violento.

Dialeticamente, a questão das águas transfronteiriças também abre a possibilidade de um cenário conflitivo proporcionar a cooperação. Isso pode ocorrer quando uma disputa se aproxima de um cenário de conflito violento e os Estados envolvidos avaliam que a cooperação é uma opção melhor do que a guerra. Avaliações semelhantes também podem suscitar medidas preventivas em bacias hidrográficas transfronteiriças de alto potencial conflitivo.

Um de nossos objetivos centrais será identificar quais são as variáveis que determinam o potencial conflitivo de uma bacia hidrográfica transfronteiriça e como estas variáveis podem influenciar a decisão dos Estados frente à questão do compartilhamento das águas transfronteiriças superficiais. Sustentaremos que tais variáveis são definidas por fatores geográficos e políticos, premissa que justifica a pertinência da abordagem da geografia política sobre o tema.

Pertinência que é reforçada quando consideramos a importância da água como recurso para as políticas territoriais dos Estados. Isto porque concordamos com o geógrafo Wanderley Costa (1992) no entendimento de que:

cabe à geografia política a tarefa nada trivial, dentre outras, de examinar e interpretar os modos de exercício do poder estatal na gestão nos negócios territoriais e a própria dimensão territorial das fontes e manutenção de poder em geral (COSTA, 1992:15).

A água ao longo da história tem se mostrado como um relevante instrumento de poder estatal e suas funções nas políticas territoriais estão no centro de estratégias múltiplas.

Claude Raffestin (1993) está entre os geógrafos que examinaram a importância dos recursos naturais como suporte para a manutenção do controle do Estado sobre o território. Em relação a água o autor constata:

Foi se o tempo que a água era considerada um bem livre. Ela só 0 era (...) onde era superabundante em relação às necessidades. $\mathrm{A}$ 
procura, depois o controle e a administração da água preocuparam todos os grupos humanos. Como o solo cultivável a água é um trunfo, bem mais ainda que no passado. De fato, no passado as sociedades que elaboravam 'políticas da água' estavam localizadas em zonas de fraca precipitação e de temperatura média elevada, como no Egito, na Mesopotâmia, em certas regiões da China etc. Hoje por causa da utilização e do consumo aumentados pelos crescimento demográfico e econômico, todos os países se confrontam com problemas relacionados a água. A água como qualquer outro recurso é motivo para relações de poder e conflitos. (Raffestin, 1993, 231).

Ao avaliar os fundamentos da geografia política, o geógrafo Joan-Eugeni Sánchez escreveu que "o acesso e apropriação de recursos físicos será um dos mobilizadores da atuação humana, sendo um dos fatores aos quais haverá de recorrer para se analisar os processos sócio-territoriais ao longo da historia da humanidade" (SÁNCHES, 1992:51).

Sánches prossegue defendendo a necessidade de se considerar a posição geo-estratégica que ocupam os grupos humanos, tanto de ponto de vista das formas geográficas quanto dos recursos contidos no território, nas análises dos processos sócio-territoriais (SÁNCHES, 1992:52).

Ao analisarmos os postulados de Sánches (1992:52) à luz das constatações de Raffestin (1993:231) concluímos que a questão da "política da água" exemplifica com perfeição as idéias sintetizadas neste último parágrafo.

Em especial, as águas superficiais contidas em rios internacionais, apresentam inúmeras funções geo-estratégicas para os Estados contemporâneos. O jurista Jacques Sironneau (1996) evidencia esse fato ao apontar que os cursos d'água internacionais podem ser utilizados como: limite fronteiriço, meio estratégico ou tático e como pressão ou propaganda estatal.

Como a geografia e história nos mostram, tanto rios quanto lagos internacionais, em função de sua visibilidade e outras questões técnicas, são largamente utilizados como limite fronteiriço. A TABELA 1.2 apresenta o percentual 
de limites fronteiriços definidos pelo suporte hidrográfico em relação à extensão total desses limites.

TABELA 1.2: Limites fronteiriços definidos por rios internacionais

\begin{tabular}{|l|l|}
\hline Continente & $\%$ \\
\hline América Latina & 52 \\
\hline África & 34 \\
\hline Europa & 25 \\
\hline Ásia & 23 \\
\hline Média Mundial & 32 \\
\hline
\end{tabular}

Fonte: SIRONNEAU, 1996

Por sua vez, os elementos orográficos que delimitam bacias e sub-bacias hidrográficas também apresentam relevância na demarcação dos limites fronteiriços. A TABELA 1.3 apresenta o percentual desses limites definidos por linhas de crista ou linhas divisoras de água.

TABELA 1.3: Limites fronteiriços definidos por elementos orográficos

\begin{tabular}{|l|l|}
\hline Continente & $\%$ \\
\hline Ásia & 35 \\
\hline América & 27 \\
\hline Europa & 21 \\
\hline África & 13 \\
\hline Média Mundial & 24 \\
\hline
\end{tabular}

Fonte: SIRONNEAU, 1996 
$\mathrm{Na}$ América latina, por exemplo, os limites fronteiriços definidos pelos divisores e pelos rios correspondem a $75 \%$ dos traçados fronteiriços (SIRONNEAU, 1996:8).

Sob o ponto de vista geo-militar, as águas superficiais podem assumir múltiplas funções estratégicas e táticas. Os rios podem ser empregados na função de proteção do território quando se apresentam como obstáculos naturais (ou possibilitam a construção de diques) frente à agressão inimiga, servindo como meio defensivo. Por outro lado, rios e lagos assumem funções ofensivas quando são utilizados como de vias de infiltração em território inimigo ou possibilitam infligir perdas ao adversário, por meio de desvio ou envenenamento de fontes e até mesmo pela destruição de obras hidráulicas (SIRONNEAU, 1996:10-14).

As ATS também podem representar objeto de dissuasão internacional, isso quando países a montante utilizam sua posição geográfica privilegiada como meio de pressão a países situadas a jusante. Rios e lagos ainda podem servir como meio de propaganda, quando de regimes nacionalistas optam pela construção de grandes obras hidráulicas, fenômeno já observado na Líbia, Egito e Iraque (SIRONNEAU, 1996: 14).

O cientista político Leonel Mello (1999) apresentou em sua tese de livre docência um importante trabalho em geopolítica. Após recuperar autores clássicos, defende a atualidade do núcleo duro das idéias do geógrafo inglês Halford Mackinder, enfatizando a importância do poder terrestre para a compreensão do cenário internacional pós guerra fria. Considerando que os rios podem representar suportes para a manutenção do controle do Estado sobre o território, entendemos que o fato das ATS se localizarem sobre as superfícies continentais contribui para reafirmação do poder terrestre postulado por Mackinder.

Assim como Raffestin (1992), Ribeiro (2004) entende que o controle e a posse da água são, sobretudo, de natureza política.

Para identificar uma "geografia política da água", Ribeiro (2004) ponderou as condições naturais da oferta de água no mundo, combinando-as com a divisão política e o consumo per capita dos países. O geógrafo brasileiro defende que para analisarmos as alternativas que surgem frente a grande disparidade entre estoques 
hídricos e consumo torna-se necessária uma releitura das categorias território e soberania (RIBEIRO, 2004:11).

Nesse trabalho Ribeiro (2004) também considerou as demandas surgidas ao longo do século XX com a construção de uma ordem ambiental internacional (RIBEIRO, 2001). Nesse sentido, conclui:

A edificação de uma ordem ambiental da água ainda está frágil e carece de um aparato institucional (...). A releitura de autores da ciência política e da geografia política permite continuar a afirmar a prevalência do realismo político com a teoria da interdependência, configurando um subsistema no sistema inter-estatal para o caso dos recursos hídricos (RIBEIRO, 2004:212).

Nosso trabalho pretende contribuir na elaboração do arcabouço teórico que vem sendo construído por Ribeiro (2001 e 2004), à medida que abordará a questão das ATS como um subsistema específico da ordem ambiental internacional. Demonstraremos que, assim como no caso dos recursos hídricos em geral, o subsistema relativo as ATS ainda está em construção e tem apresentado a prevalência do realismo político, mesclado com a teoria da interdependência.

Também estamos convencidos da centralidade das interações territóriosoberania na compreensão do compartilhamento das ATS. Afinal, é o princípio da soberania que constitui a base de sustentação das relações interestatais do mundo contemporâneo.

Somente Estados soberanos participam plenamente do sistema internacional. A Carta das Nações Unidas salienta que a organização é baseada no principio da igualdade soberana de todos os seus membros. Além disso, "todas as constituições que regem os países atuais a reconhecem de forma explicita" (HELLER, 1995:5). Daí a já tradicional importância deste conceito no estudo da teoria do Estado e do Direito.

Porém verificamos que a dimensão territorial deste conceito tem sido pouco analisada. Defendemos que a geografia política pode apresentar uma importante contribuição para suprimir essa lacuna, em nosso entendimento a pertinência da 
geografia frente a esse conceito, nasce do fato de que "a soberania sobre determinado território é um dos quatro componentes clássicos de um Estado contemporâneo" (SOARES, 1993:21).

Raffestin também aponta a soberania e o território como pré requisitos do Estado:

Se há um conceito sobre o qual os geógrafos concordam é com certeza o da definição de Estado: 'O Estado existe quando uma população instalada num território exerce a própria soberania'. Portanto, três sinais são mobilizados para caracterizar o Estado: a população, o território e a autoridade (RAFFESTIN, 1993:22).

A indivisibilidade entre soberania, Estado e território é um pressuposto que acompanha a geografia política desde seus primórdios. Friedrich Ratzel (1983), pioneiro na sistematização desse ramo do saber geográfico, ao analisar as relações entre solo, sociedade e Estado, constatou a defesa da soberania como principal tarefa estatal:

\begin{abstract}
A tarefa do Estado, no que concerne ao solo, permanece sempre a mesma em princípio: o Estado protege o território contra ataques externos que tendem a diminuí-lo. No mais alto grau da evolução política, a defesa das fronteiras não é a única a servir nesse objetivo; comércio, o desenvolvimento de todos os recursos que contém o solo, numa palavra, tudo aquilo que pode aumentar o poder do Estado a isso concerne igualmente. A defesa do território (pays) é o fim último que se persegue por todos os meios (RATZEL, 1983:96).
\end{abstract}

No que pese as críticas a certas proposições deterministas do geógrafo alemão, defendemos a contemporaneidade de muitos de seus postulados, como o contido nesse fragmento. Afinal perguntamos: Não seriam as grandes negociações ambientais contemporâneas, uma das formas de materialização daquilo que Ratzel (1983) se referiu como "mais alto grau da evolução política"? Não se encaixaria em "todos os recursos do solo" os objetos de tais negociações - como, por exemplo, a biodiversidade ou os recursos hídricos? Acreditamos que sim, e, como 
demonstraremos, os Estados contemporâneos têm procurado proteger seu direito soberano sobre tais recurso perante as já referidas rodadas de negociação.

Camille Vallaux (1914), geógrafo que se dedicou a recuperar e superar os postulados de Ratzel, também "reconhece que é inevitável que a formação dos Estados passe necessariamente pela definição da soberania de um povo sobre uma porção determinada de solo, definindo aí um território" (COSTA, 1992:45).

Utilizaremos nesse trabalho o termo soberania territorial para nos referirmos à totalidade de direitos e competências de um Estado dentro de seu território. E é nesta interface entre soberania e território, que a geografia política pode proporcionar uma relevante e original interpretação. Defendemos que, cabe a esse campo da geografia analisar as mais diversas formas de interação entre esses dois elementos, em especial como os atributos territoriais facilitam ou limitam o exercício da soberania territorial ou como os mesmos atributos interferem na face externa das soberanias estatais.

Por isso acreditamos que nas análises das questões ambientais transnacionais tais interações não podem ser negligenciadas. Caberia à geografia política esclarecer questões como: em qual medida os atributos do território influenciam nas posturas políticas dos Estados frente às negociações internacionais? Como a adesão a um tratado internacional pode limitar o princípio de soberania dos Estados Partes? Como as formas de apropriação e gestão dos territórios nacionais podem restringir a soberania territorial de outros Estados? Quais os condicionantes geopolíticos que podem levar os Estados a conflitos de matriz ambiental? Entre muitas outras questões.

Uma dos objetivos desse trabalho é demonstrar como os fatores geográficos e políticos podem influenciar nas decisões - soberanas? - dos Estados frente às disputas e negociações ambientais que envolvem o compartilhamento das ATS.

Considerando que nossa tarefa enfocará os fatores geográficos e políticos envolvidos na questão, temos a expectativa de produzir subsídios para a elaboração de uma "geografia política das águas transfronteiriças superficiais". Para tanto, nos embasaremos em autores, clássicos e contemporâneos, da geografia e da ciência 
política, que trataram sobre o tema ou sobre conceitos relacionados. Também serão ponderadas as contribuições de autores, de diversas áreas, que analisaram os desafios ambientais impostos às ATS.

No intuito de analisar como as variáveis e os processos que envolvem a questão se materializam em um caso concreto, estudaremos as disputas e iniciativas interestatais de compartilhamento das ATS da bacia do rio Danúbio. Como teremos oportunidade de demonstrar, suas características políticos-territoriais tornam essa bacia um caso emblemático.

Por ora, destacamos que se trata da bacia hidrográfica transfronteiriça com o maior número de países co-ribeirinhos do globo (17 Estados), situada em uma região de intensas transformações geopolíticas ao longo do século $\mathrm{XX}$ e que possui uma artéria de vital importância para circulação hidroviária européia. Além disso, foi nessa bacia que surgiu a primeira - e por enquanto única - demanda jurídica referente as ATS arbitrada pelo Tribunal de Haia, contencioso que envolveu a Eslováquia -então Tchecoslováquia - e Hungria.

Buscaremos, utilizando esse estudo de caso, responder questões relacionadas a segurança ambiental, soberania territorial, potencial conflitivo e suas iniciativas mitigadoras, entre outras.

Porém, antes de abordarmos os eventos da bacia do Danúbio temos um longo caminho a percorrer. Iniciaremos analisando mais detidamente uma das premissas teóricas de nosso trabalho: a evolução da ordem ambiental internacional. 


\section{Capítulo 2 - A ordem ambiental internacional e seus desafios}

Neste capítulo apresentaremos nossa principal premissa teórica: demonstraremos, fundamentados nas constatações do geógrafo Wagner Ribeiro, que há uma ordem ambiental internacional em construção desde os primórdios do século XX. Cotejando os trabalhos do geógrafo com os de outros analistas, explicitaremos os atores principais e a lógica desse processo. Essa tarefa mostra-se vital em nossa dissertação, já que entendemos que a questão do compartilhamento das águas transfronteiriças superficiais (ATS) nada mais é do que um subsistema interno dessa ordem.

Ainda nesse capítulo, abordaremos duas questões que ganham novas dimensões à medida que a ordem ambiental internacional evolui. A primeira delas diz respeito às preocupações e desafios em torno da busca da segurança ambiental internacional. A outra nos remete à discussão sobre a validade do princípio da soberania nacional, tema que nos leva a refletir sobre o papel do Estado perante o caráter transnacional dos fenômenos ecológicos.

Nossa intenção é criar subsídios teóricos para avaliarmos tais questões diante do compartilhamento das ATS, tarefa que realizaremos nos capítulos posteriores.

\section{1 - A construção da ordem ambiental internacional}

Acompanhamos, ao longo dos últimos vinte anos do século passado, a questão ambiental adquirir uma posição na agenda internacional de destaque sem precedentes. Os fatores de explicam esse fenômeno não são poucos e as conseqüências são ainda mais numerosas.

A preocupação com a temática começou a tomar sua devida posição nas relações internacionais à medida em que a distensão geopolítica, entre primeiro e segundo mundo, avançava. Identificamos, ao menos, dois aspectos próprios da 
détente que contribuíram para esse processo: (1) a ameaça nuclear incitou o surgimento de vários grupos pacifistas, que originalmente postularam a luta contra a guerra atômica como principal bandeira e posteriormente ampliaram suas reivindicações ambientais; (2) a gradual e relativa aproximação entre as superpotências rivais, possibilitou que o tema da segurança, em seu sentido tradicional, deixasse de "monopolizar" a pauta internacional, abrindo caminho para as "novas" demandas internacionais, tais como direitos humanos e meio ambiente.

Simultaneamente a esse processo, a denominada "crise ambiental" começa a ser identificada e seus malefícios propagados. Problemas de escassez de recursos naturais e de espaço físico para depósito de dejetos, além de desarranjos nos ecossistemas naturais passam a gerar grandes temores, tanto para aqueles que se preocupam com o bem-estar das atuais e futuras gerações, quanto para aqueles que se importam com a manutenção da base natural necessária para a reprodução ampliada do capital. Desafios que se materializam na crise do petróleo, nos impactos da chuva ácida, nas disputas por águas transfronteiriças, entre tantos outros problemas.

Considerando-se o caráter transnacional envolvido nas questões ambientais, multiplicaram-se, desde então, a realização de Conferências e a elaboração de Convenções internacionais, visando à regulação das ações antrópicas no meio ambiente. Juntamente com as preocupações ambientais surge um amplo cenário de disputas no qual os Estados procuram influenciar para que as decisões ofereçamIhes ganhos (econômicos e/ou políticos). Nesse cenário surgiram novas oportunidades de trocas comerciais e interpretações sobre o controle dos recursos naturais que merecem reflexão. Acreditamos que ao analisarmos tal processo temos oportunidade de compreendermos o funcionamento de parte da dinâmica da atual ordem internacional.

A análise da questão ambiental nas relações internacionais teve uma abordagem inédita no trabalho de Wagner Ribeiro (2001), no qual o geógrafo examinou a realização e negociação de tratados e conferências sobre o tema e 
constatou que acompanhamos a construção de uma ordem ambiental internacional (OAI).

O principal objetivo da OAI seria:

regular as ações humanas em escala internacional para evitar que as condições de habitabilidade humana no planeta sejam perdidas e/ou regular as relações hegemônicas do capitalismo internacional entre as partes envolvidas em cada questão que é trazida à discussão" (RIBEIRO, 2001 a:1).

Trata-se de um lento processo, iniciado no início do século $X X$, que é periodizado em três 3 grandes etapas, a saber: (1) dos primeiros tratados até o final da Segunda Guerra Mundial; (2) a época da Guerra Fria, que é subdivida pela realização da Conferência de Estocolmo, em 1972 e (3) o período pós Guerra Fria, no qual destaca-se a Conferência do Rio, ocorrida em 1992. Como podemos constatar, essa organização demonstra a importância que a ordem bipolar do pós Segunda Guerra, desempenhou nas relações internacionais durante o século passado, já que é a partir dela que Ribeiro (2001) apreende as principais descontinuidades da OAI.

Para Ribeiro (2001) as raízes desse processo remontam a 1900, quando a Coroa inglesa realizou em Londres uma reunião internacional, com o objetivo de discutir a caça indiscriminada nas colônias africanas. O primeiro intervalo foi marcado por tentativas escassas e pontuais de estabelecer acordos internacionais que regulassem a ação humana sobre o ambiente.

Ao longo do segundo período as discussões internacionais sobre a temática ambiental passaram a ser capitaneadas por organismos supranacionais vinculados à ONU, especialmente a FAO (Organização das Nações Unidas para Agricultura e Alimentação) e a UNESCO, porém tais iniciativas proporcionaram poucos avanços. Ribeiro (2001) ressalta que esses encontros envolveram poucos países e não conseguiram dar à população mundial visibilidade sobre a questão ambiental, além disso, as reuniões se pautaram em temas, que apesar de incidir diretamente sobre a vida humana, não representavam os mesmos graus de riscos que se tornaram 
públicos a partir da divulgação de estudos ambientais nas décadas de 1980 e 1990.

A temática ambiental somente ganhou escopo institucional após a reunião de Estocolmo, em 1972. Tratou-se da primeira mega-conferência da ONU convocada especialmente para a discussão de problemas ambientais, foi realizada na capital da Suécia e oficialmente denominada Conferência sobre Meio Ambiente Humano. Entre os temas que pautaram o encontro destacaram-se a questão da poluição atmosférica, fruto do longo processo de industrialização, e a pressão que o crescimento demográfico exerce sobre os recursos naturais da Terra.

Ainda na avaliação de Ribeiro (2001), o principal desdobramento dessa reunião ${ }^{7}$ foi a criação do PNUMA, em 1973, que passou a catalisar as demandas ambientais. Após analisar as dificuldades do Programa, o geógrafo reconhece que ele nasceu esvaziado e sem poder, mesmo assim acredita que com o passar das décadas suas realizações foram muitas e alcançaram objetivos relevantes, pois sob seus auspícios foram realizadas inúmeras rodadas das OAI.

Após a reunião de Estocolmo acompanhou-se uma gradual afirmação da temática na agenda internacional. Nos vinte anos posteriores ao encontro na Suécia, constatou-se a institucionalização da temática ambiental na ONU, já que essa passou a desempenhar um crescente papel de mediadora e reguladora das disputas ambientais internacionais. A principal evidência desse fato foi a criação de importantes mecanismos multilaterais com a finalidade de regular as intervenções humanas no meio ambiente. ${ }^{8}$ Além da participação do PNUMA, que assessorou reuniões, financiou estudos em países periféricos e capacitou pessoal; outros fatores contribuíram para esse cenário: o aumento do conhecimento científico sobre alterações nos sistemas naturais e a maior participação das ONGs (Organizações

\footnotetext{
${ }^{7}$ Entre as principais decisões dessa Conferência também merecem destaque: a Declaração de Estocolmo, que ainda hoje é lembrada como uma importante declaração de princípios, mas que não levou a resultados práticos e um Plano de Ação que, na realidade, não ultrapassou o plano das intenções.

${ }^{8}$ Ribeiro destaca, considerando as duas décadas posteriores a Conferência de Estocolmo, os seguintes mecanismos: Convenção sobre Comércio Internacional de Espécies de Flora e Fauna Selvagens em Perigo de Extinção (1973); Convenção sobre Poluição Transfronteiriça de Longo Alcance (1979); Convenção de Viena para a Camada de Ozônio (1985); Protocolo de Montreal sobre Substâncias que destroem a Camada de Ozônio (1987) e a Convenção da Basiléia sobre o Controle de movimentos Transfronteiriços de Resíduos Perigosos e seu Depósito (1989).
} 
Não Governamentais), que ampliou a capacidade de mobilização da opinião pública internacional para os temas ambientais.

Certamente foi no último período estabelecido por Ribeiro (2001) - do pósguerra fria - que a OAI adquiriu sua máxima complexidade. Foi nesse contexto que ocorreu a segunda mega-conferência ambiental organizada pela ONU. A reunião, denominada oficialmente Conferência das Nações Unidas para o Meio Ambiente e Desenvolvimento (CNUMAD), teve sede na cidade do Rio de Janeiro, em 1992, e é considerada o mais importante marco das decisões ambientais internacionais, pois seus documentos ${ }^{9}$ ganharam visibilidade perante a opinião pública, além de fortalecer a temática em outros fóruns internacionais.

Sob o aspecto da mobilização política e da repercussão na opinião pública, via imprensa internacional, a CNUMAD foi considerada por Ribeiro (2001) um sucesso. Os números apresentados por Le Prestre (2000) sustentam essa avaliação:

A conferência mobilizou praticamente o mundo inteiro. Reuniu 178 países, oito mil delegados, dezenas de OlGs [Organizações Internacionais Governamentais], três mil representantes de ONGs, mais de mil ONGs num fórum paralelo, nove mil jornalistas. Na sessão final, 103 chefes de Estado e de governo estavam sentados ao redor de uma mesa (...) se cada um tirou do evento sua própria opinião, todos estavam conscientes de que viviam um momento de grande simbolismo (LE PRESTRE, 2000:201).

$\mathrm{Na}$ CNUMAD, buscou-se conciliar objetivos que eram entendidos como antagônicos na Conferência de Estocolmo: conservação ambiental e desenvolvimento. A iniciativa foi pautada pelo conceito de desenvolvimento sustentável que, segundo Ribeiro (2001), passa a ocupar um papel central para o

\footnotetext{
${ }^{9} \mathrm{Na}$ CNUMAD foram elaboradas duas Convenções internacionais, uma tratando das mudanças climáticas globais e outra da necessidade de manutenção da biodiversidade. Além de duas Declarações: a do Rio e a de Florestas, tratam-se de cartas de princípios pela preservação da vida na Terra e das florestas, respectivamente. Outro documento produzido foi a Agenda 21, que é um plano de ação, dividido em 40 capítulos, que visa mitigar os problemas ambientais globais.
} 
estabelecimento da $\mathrm{OAI}^{10}$. Mesmo reconhecendo os avanços, ao final da análise dos principais resultados dessa mega-conferência o geógrafo conclui:

o ambiente natural foi entendido pelos países envolvidos como um instrumento a serviço da sociedade de consumo. Na ordem ambiental internacional o ambiente ainda é tido como algo exterior à representação da vida. Mais que isso, a sociedade hegemônica (de base ocidental) recria a própria vida reproduzindo-a em laboratórios de pesquisa. Pensa e produz o ambiente como recurso natural. Mesmo com a consciência da limitação dos recursos não se propôs, na CNUMAD, a transformação das relações que reproduzem a vidainclusive humana - como chegou a ser veiculado por seus organizadores (RIBEIRO, 2001:130).

Quanto à gestão dos recursos hídricos a principal contribuição da CNUMAD ficou registrada na Agenda 21. No capítulo 18 deste plano de ação encontram-se premissas pertinentes ao uso sustentável da água doce. As recomendações do documento apontam a necessidade de: planejamento e administração integrados, combate ao desperdício, ampliação de instalações de tratamento de esgoto e lixo industrial, proteção dos aqǘferos, busca de técnicas de irrigação mais eficientes, adoção de técnicas de prevenção a enchentes, entre outras medidas.

As águas transfronteiriças são citadas na seguinte passagem:

Os recursos hídricos transfronteiriços e seu uso são de grande importância para os Estados ribeirinhos. Nesse sentido, a cooperação entre esses Estados pode ser desejável em conformidade com acordos existentes e/ou outros arranjos pertinentes, levando em consideração os interesses de todos os Estados ribeirinhos envolvidos (CNUMAD, 1995).

Apesar de sua repercussão, a CNUMAD não representou nem o começo nem o fim da OAI. Outras rodadas ocorreram e continuam a ocorrer, nas quais são

\footnotetext{
${ }^{10}$ Juntamente com o conceito de segurança ambiental internacional, que será abordado no próximo item deste capítulo.
} 
tratadas novas e antigas preocupações ambientais, como por exemplo: meio ambiente e comércio mundial, biossegurança, mudanças climáticas, desertificação, além do compartilhamento das ATS, que será analisado nos próximos capítulos desse trabalho.

Para interpretação da OAI, Ribeiro (2001) elaborou um arcabouço teórico que combinou matrizes do pensamento político e da geografia política. Entre os autores do primeiro ramo do conhecimento, destacam-se: Raymond Aron (2002), Hans Morgenthau (1973) e Manfred Wilhelmy (1991); do segundo ramo, o destaque fica para Friedrich Ratzel (1914; in: Moraes, 1990) e Claude Raffestin (1993).

Partindo dos postulados de Aron (2002), que definem as relações internacionais de maneira sistêmica, a OAl é entendida como:

um subsistema específico do sistema internacional, com características de um sistema heterogêneo e multipolar. Na verdade, no interior da OAl são identificados vários subsistemas, um para cada documento acordado (RIBEIRO, 2001:35).

Esse subsistema é organizado preferencialmente pela ONU, por meio de suas diversas agências especializadas, como o PNUMA, a UNESCO, a UNECE (Comissão Econômica das Nações Unidas para a Europa), entre outras. Ressaltamos que algumas rodadas da OAI ocorrem sem a intervenção direta da ONU, como o caso de muitos acordos bilaterais ou regionais pelo compartilhamento das ATS.

O geógrafo afirma que apesar de preceitos que demonstram preocupação ambiental serem aceitos pelos principais Estados envolvidos, seus representantes têm tomado posição segundo seus interesses nacionais frente a cada subsistema interno da OAl. Assim, os Estados têm adotado atitudes políticas distintas para cada situação, salvaguardando sua soberania. Em suas próprias palavras:

em que pese o reconhecimento destas duas premissas [segurança ambiental global e desenvolvimento sustentável] e de que elas envolvem a promoção de ajustes globais, nos quais os vários atores do sistema internacional certamente devem contribuir para que metas comuns sejam alcançadas, os países, principais interlocutores na 
ordem ambiental internacional, por meio dos seus negociadores, têm procurado salvaguardar o interesse nacional. Agindo desta forma, transformam as preocupações com sustentabilidade do sistema econômico hegemônico e a possibilidade de que ele nos encaminhe para uma situação de risco em mera retórica (RIBEIRO, 2001 a:2).

Em muitos casos, as polêmicas e dúvidas científicas sobre a real repercussão de determinados impactos ambientais servem de argumento para decisões que, na verdade, buscam manter posições hegemônicas e/ou conquistar novas oportunidades no sistema internacional. Concluímos, então, que nessas situações o princípio da precaução ${ }^{11}$ é ignorado ${ }^{12}$.

Ribeiro (2001) entende que as atitudes dos Estados que muitas vezes não assinam ou não ratificam os documentos, sempre defendendo seus interesses nacionais, são posturas próprias do realismo político, de acordo com o exposto por Morgenthau. Segundo esse autor: "o realismo admite que a idéia de interesse é realmente a essência da política e que não é afetada pelas condições de tempo e lugar" (MORGENTHAU, 1973:5; apud RIBEIRO, 2001:18).

O pensador alemão explicita a lógica que nos ajuda compreender as contradições entre o discurso retórico de certos Estados que expressam preocupações ambientais e suas atitudes efetivas:

Realismo sustenta que princípios morais universais não podem ser aplicados às ações dos Estados em sua formulação universal abstrata, mas que eles devem ser filtrados por circunstâncias

\footnotetext{
${ }^{11}$ Para proteger o ambiente, a abordagem preventiva deve ser amplamente aplicada pelos Estados, de acordo com suas capacidades. Quando houver ameaças de dano sério ou irreversível, a ausência de plena certeza científica não deve ser utilizada como razão para o adiamento de medidas de custo efetivo para evitar a degradação ambiental (Princípio 15, Declaração do Rio; apud SACHS,1993:101).

12 Entre muitos casos que poderiam ilustrar essa última constatação, utilizaremos um que adquiriu grande visibilidade na mídia internacional, por envolver uma superpotência e referir-se a uma das maiores preocupações ambientais contemporâneas. Trata-se da decisão de George W. Bush - em março de 2001- de resguardar os EUA dos compromissos de redução de emissão de gases estufa, firmados pelo Protocolo de Kyoto, no ano de 1997. Decisão que foi tomada sob o pretexto de que não há convicção científica das relações entre a emissão de $\mathrm{CO}_{2}$ e o aquecimento global, mas na verdade, isenta o maior responsável pela emissão do principal gás estufa do ônus econômico de buscar fontes energéticas mais limpas.
} 
concretas de tempo e lugar (MORGENTHAU, 1973:10 - tradução do autor).

Ribeiro (2001) constata que Morgenthau inspirou-se nos escritos de seu compatriota e geógrafo Friedrich Ratzel, porém ressalta que essa influência:

não reflete uma simples assimilação do determinismo geográfico alemão, mas uma exposição estratégica das virtudes geográficas de um país, quais sejam sua localização, posição, configuração elementos naturais que facilitam a defesa ou a consignação de objetivos estratégicos (RIBEIRO, 2001:23-24).

Em sua tese de livre docência o geógrafo brasileiro reafirma que algumas postulações de Ratzel merecem ser reconsideradas para compreensão da OAI. Especialmente aquelas que nos remetem a "considerar os povos sobre seus territórios e avaliar a disponibilidade da base natural que sustenta a reprodução da vida" (RIBEIRO, 2004:8).

Ainda nesse trabalho, Ribeiro (2001) ressalta a importância da obra de Claude Raffestin (1993) na avaliação dos interesses nacionais dos Estados mais poderosos frente a OAl. Já que o geógrafo canadense:

destaca a importância dos recursos naturais para um país pleitear a condição de potência. Para ele, a oferta de recursos é uma das variáveis centrais, dado que possibilita ao país prover sua matriz material armamentista. Mas é preciso ainda dispor de tecnologia capaz de produzir os equipamentos de ação militar (RIBEIRO, 2004:8).

Outros autores também identificaram matrizes do realismo político, como defesa dos interesses nacionais, a salvaguarda da soberania e até um caráter conflitivo, nas relações internacionais frente a questões ambientais. Entre eles encontra-se o cientista político Shiguenoli Miyamoto. Em um trabalho publicado 
pouco antes da Conferência do Rio, ele constata que as relações de força ou poder ainda são determinantes no contexto internacional e complementa:

Se este modo de agir faz parte do cotidiano das políticas desenvolvidas pelas grandes potências na defesa de seus interesses políticos, ideológicos, econômicos ou estratégicos-militares, buscando resguardar suas soberanias, neste caso percebidas como invioláveis, idêntica postura é reproduzida no âmbito da questão ambiental (MIYAMOTO, 1992:7).

Por seu turno, Rafael Grasa, professor de Relações Internacionais da Universidade Autônoma de Barcelona, afirma:

las negociaciones ambientales constituyen una oportunidad y un espacio en que, aunque se busque la cooperación, se manifiesta siempre un rasgo permanente de las relaciones internacionales: su naturaleza conflictiva (GRASA, 1994:37).

Em outra passagem esse autor reafirma sua interpretação realista, ao apontar causas que dificultam a cooperação ambiental inter-estatal, seriam elas:

[1] el conflicto Norte-Sur, que se agrava a medida que se ensancha la distancia entre los países del Norte y los del Sur (...); [2] el interés de los estados en preservar su soberanía frente a otros estados y organizaciones internacionales, per se un objetivo irrenunciable para ellos; y [3] la falta de incentivos que fomenten la negociación seria entre estados (GRASA, 1994:38).

Retomando os postulados de Ribeiro (2001), esclarecemos que o geógrafo ressalta que nem todas as evidências apontadas na formulação teórica realista de Morghentau (1973) são observadas na OAl. A importância do poder militar, por exemplo, não se confirma, já que:

o direito de dispor de armas e do exercício da força - instrumento de ação dos Estados e entre Estados - fica restrito quando se formulam instrumentos mais amplos de discussão, como as Conferências internacionais (RIBEIRO, 2001:37). 
Por isso, até países inexpressivos militarmente têm adotado a defesa de seus interesses nacionais como base de ação política nos mecanismos da OAl.

Mas apesar da predominância do realismo político em suas esferas de decisão, a OAl é extremamente complexa para ser explicada com uma única matriz teórica. Por isso, Ribeiro (2001) incorpora à sua concepção a teoria da interdependência, proposta inicialmente por Nye e Keohane (1973) e reafirmada por Columbus (1986), especialmente pelo fato dessa reconhecer a atuação de agentes não estatais no sistema internacional: ONG's e empresas transnacionais.

Ribeiro (2001) reforça esse ponto de vista citando o cientista político Manfred Wilhelmy que afirma:

o estado deixa de monopolizar o manejo das relações exteriores e agentes não governamentais passam a intervir nelas (...). Estes novos agentes podem intervir na vida internacional, seja atuando direto com outras sociedades, por meio de setores pertinentes da burocracia nacional, ou mediante seu acesso a organismos ou foros internacionais que se ocupam de temas afins com seus interesses (WILHELMY, 1991:73; apud RIBEIRO, 2001:35).

Mesmo demonstrando as dificuldades na busca efetiva da sustentabilidade, o geógrafo conclui afirmando que não é preciso desanimar, pois avanços foram conquistados $^{13}$.

Outro trabalho de destaque nessa temática foi realizado pelo biólogo e cientista político Philippe Le Prestre (2000). Ao analisar as dimensões políticas internacionais dos problemas ambientais, esse autor também ressalta a defesa dos interesses dos atores envolvidos. A definição do título de seu trabalho evidencia essa concepção:

A ecopolítica internacional não somente faz referência ao conjunto das dimensões políticas da identificação e da resolução das questões

\footnotetext{
${ }^{13}$ Podemos apontar a entrada em vigor Protocolo de Kyoto, em 2005, para confirmar tais avanços e reforçar as esperanças daqueles que compartilham dessa visão otimista. Resta saber se a velocidade desses avanços será capaz de deter as inúmeras e crescentes formas de degradação dos recursos naturais.
} 
ambientais, como, mais particularmente, às tentativas dos atores internacionais de impor sua definição da segurança em face da natureza e da qualidade de vida das populações, utilizando as novas carências em proveito próprio (LE PRESTRE, 2000:19).

Esse autor identifica como atores importantes da ecopolítica internacional: os Estados, as organizações internacionais governamentais (OIGs), empresas transnacionais (ETNs), indivíduos, ONGs. Mas não deixa de ressaltar que os Estados são e continuarão sendo os atores dominantes, apesar de estarem sendo submetidos a novas coações, o que os leva a perder certas atribuições de sua autoridade e levar em consideração o comportamento dos outros atores (LE PRESTRE, 2000:97).

O cientista político identifica oito princípios que denotariam que a "politização" é inerente e legítima à questão ambiental na escala internacional. O segundo deles ratifica, a constatação de que a defesa dos interesses esta no cerne da questão, já que : "a definição dos problemas ambientais e as soluções escolhidas implicam certa distribuição dos custos e benefícios, certos grupos ou Estados ganham, outros perdem" (LE PRESTRE, 2000:25).

Ao analisar os motivos que levam os Estados à cooperação em questões ambientais e sob quais condições elas acontecem, Le Prestre (2000) identifica quatro atitudes possíveis. Como poderemos constatar, em todas elas a interesses nacionais em jogo:

(1) Os atores podem concluir que a realização de seus objetivos nacionais depende das ações de outros atores do sistema; tenta-se então obter a adoção dos próprios modelos e valores nacionais pela comunidade internacional. Tal atitude poderia ser chamada de imperialista retirando ao termo todo juízo de valor. (...)

(2) Inversamente, os Estados se inquietam com os esforços de outros atores para impor seus próprios valores e objetivos políticos e econômicos, que limitariam sua autonomia. Entram, então, na arena internacional primordialmente para se proteger e adotam um 
comportamento defensivo. Esta atitude é talvez a mais corrente em matéria de política ambientalista exterior. (...)

(3) Um terceiro grupo procurará utilizar uma implicação internacional no domínio, principalmente a fim de obter concessões ou vantagens em outro domínio. Conquanto esta atitude se verifique em todos os outros atores, o que distingue este grupo é sua motivação prioritária. Em geral, tais Estados consideram a questão do respeito às obrigações mas não se posicionam verdadeiramente, uma vez que não vêem senão como um compromisso vago e remoto. Seria possível classificar este comportamento como instrumental. (...)

(4) Os atores podem concluir, diante da natureza dos problemas científicos e do caráter transnacional e interdependente dos problemas e das soluções, que a comunidade internacional deve chegar a um acordo sobre a definição e a busca do interesse comum. É evidente que nenhum dos atores agirá contrariamente aos seus interesses, mas a motivação principal não é a de impor interesses ou valores já definidos, mas de encontrar uma solução otimizada no interior de certos parâmetros ditados pela viabilidade política e pelos interesses do Estado - comportamento internacionalista (LE PRESTRE, 2000:281-284).

Concluímos que as três primeiras atitudes identificadas por Le Prestre (2000) - imperialista, defensiva e instrumental - são claras demonstrações do realismo político praticado pelos Estados, já que a defesa dos interesses nacionais prevalecem. Como podemos depreender do fragmento acima, são esses os comportamentos predominantes, especialmente aquele classificado como defensivo.

Mesmo na única situação na qual o interesse comum prevalece comportamento internacionalista - os interesses nacionais também não são frontalmente contrariados. Nessas situações identificamos que os apontamentos da teoria da interdependência também têm lugar na ecopolítica internacional proposta por Le Prestre (2000). 
A partir dessas constatações defendemos que há uma considerável convergência nas conclusões de Ribeiro (2001) e Le Prestre (2000), à medida que os dois apontam para o predomínio do realismo político nas negociações internacionais ambientais, sem desconsiderar que também há atitudes cooperativas dos Estados, motivadas pela interdependência inerente a questão ambiental. A diferença é que o geógrafo apresenta essa constatação de forma explícita, enquanto o cientista político apresenta-a de forma discreta.

Considerando que a questão do compartilhamento das ATS está inserida na OAI identificada por Ribeiro (2001) ou na Ecopolítica Internacional, como prefere Le Prestre (2000), analisaremos no próximo capítulo a evolução das rodadas de negociações e iniciativas de regulamentação relativas a tal compartilhamento, enfatizando os aspectos geográficos e políticos envolvidos.

Antes, porém, apresentaremos um tema que emerge com a nova dinâmica que a ordem ambiental internacional alcançou nas últimas duas décadas e também se mostrará estrutural na discussão do compartilhamento das ATS. Trata-se das discussões e preocupações referentes a segurança ambiental internacional.

\section{2 - A segurança ambiental internacional}

Não são poucos os analistas que consideram a segurança ambiental como um dos temas centrais para a compreensão das questões ambientais internacionais e, por conseqüência, para análise da ordem mundial contemporânea.

O primeiro trabalho de grande repercussão internacional que sistematizou as preocupações com o tema foi o Relatório Brundtland ${ }^{14}$. O documento inicia sua abordagem sobre segurança ambiental internacional apontando o risco proveniente

\footnotetext{
${ }^{14}$ Este relatório - denominado oficialmente O Nosso futuro comum - foi publicado, em 1988, pela Comissão Mundial sobre Meio Ambiente e Desenvolvimento, que foi presidida pela norueguesa Gro Harlem Brundtland. Ele representa o esforço de uma comissão de 21 membros de diversos países que, entre 1983 e 1987, estudaram a degradação ambiental e econômica do planeta. Norteado pelo preceito do desenvolvimento sustentável, o relatório propõe soluções para os problemas identificados.
} 
das armas de destruição em massa como a principal preocupação ecológica. Defendendo um enfoque mais abrangente da questão, o documento sugeriu a existência de relações causais entre pressões sobre o meio ambiente, tensões políticas e conflitos militares, além de demonstrar preocupação com o provável aumento de conflitos relacionados a apropriação de recursos (CMMAD, 1988: 325344).

Em uma revisão bibliográfica sobre o tema, constatamos que o conceito de segurança ambiental tem apresentado um leque amplo de definições.

Rafael Grasa (1994), aborda a segurança ambiental associada à degradação ambiental. Em seu entendimento, a temática emerge no período entre a Conferência de Estocolmo e a Conferência do Rio, mas especificamente na década de 1980, e está vinculada aos riscos gerados pelas atividades econômicas em escala global. Tais riscos se cristalizariam em quatro grandes eixos: (1) o caráter limitado dos recursos da biosfera; (2) a dimensão transfronteiriça e global de grande parte dos problemas ambientais; (3) as diferenças de enfoque, entre os países fortemente industrializados e os países em desenvolvimento, a respeito de temas como ambiente, pobreza e desenvolvimento e (4) o caráter político e não meramente técnico das possíveis soluções (GRASA, 1994:27).

Ao longo de sua análise, Grasa (1994) defende a idéia de que a segurança ambiental deve ser entendida como geradora de conflitos e justifica os estudos sobre o tema como via para se manter a paz.

$O$ autor ressalta que nem todos os conflitos apresentam uma evolução violenta, porém alerta que a probabilidade desse tipo de desdobramento aumenta a medida que a disputa fica sem solução por muito tempo e quando ela afeta as necessidades básicas de sobrevivência de pessoas ou grupos. Para ilustrar essa constatação, ele avalia um quadro referente a Litigios irresueltos sobre águas internacionales -1986 (GRASA, 1994:33).

O professor da Universidade Autônoma de Barcelona, define cinco formas de conflitos induzidos por fatores ambientais: (1) os conflitos étnicos associados à escassez de recursos; (2) os de identidade grupal e privação relativa de recursos; (3) os de identidade grupal gerados pela presença de migrantes que são vistos como 
geradores de privação de recursos; (4) os conflitos de privação relativa que perseguem a justiça distributiva e a equidade, como os que aponta entre os países do Norte e os do Sul e (5) aqueles resultantes da combinação das variáveis anteriores (GRASA, 1994:35-37).

Em outro trabalho, Grasa (1998), define um quadro conceitual sobre o tema e apresenta a noção de segurança ambiental como reflexo da emergência de novas concepções sobre segurança. Ele explica que tal transformação acontece num contexto de pós guerra fria e globalização, que acarretou o "impacto combinado de la pérdida de peso de lo político y lo militar en la aceptación no generalizada de nuevas concepciones, no militares, de seguridad" (GRASA, 1998:15).

O geógrafo Peter Gleick (1994) inicia seu artigo afirmando que a segurança ambiental ou ecológica se transformou em uma das questões mais controvertidas e estimulantes no campo da segurança internacional. Prossegue reconhecendo a necessidade de novas definições de segurança que incorporem de forma explícita preocupações ambientais. Para o autor

hablar de amenazas a la seguridad supone incluir problemas económicos, sociales y ecológicos que reducen a calidad de vida, hacen aumentar la competencia y las tenciones entre grupos nacionales e sub-nacionales $y$ conducen in extremis a verdaderos conflictos violentos (GLEICK, 1994:86).

Gleick (1994) utiliza a "geopolítica da água compartilhada" como estudo de caso. Ao longo do trabalho analisa as implicações estratégicas e militares do controle dos recursos hídricos, bem como sua distribuição desigual como causa de conflitos.

A cientista política Lorraine Elliott (1998) afirma que a variedade de concepções se deve ao fato do termo - segurança ambiental - ser relativamente novo no léxico das políticas ambientais. Ela identifica duas abordagens distintas para o termo segurança ambiental. Uma delas, que seria o discurso tradicional, poderia ser definida como ambiente para segurança, visão que entende a crise ambiental como uma ameaça à segurança nacional, que conduziria a uma 
militarização das políticas ambientais. A outra enfatizaria segurança para o meio ambiente, ou seja, defenderia o aumento de segurança ao meio ambiente, levando a uma desmilitarização do pensamento de segurança (ELLIOTT, 1998:219).

A autora constata que muita atenção tem sido dada, na academia e na comunidade política, ao potencial conflitivo resultante do recrudescimento da crise ambiental, especialmente no tocante a possibilidade de confrontos entre Estados (ELLIOTT, 1998:220).

A cientista política analisa as principais causas ambientais que possuem potencial para desencadear conflitos. Seriam elas: (1) conflitos pelo controle de recursos estratégicos; (2) desigualdades sócio-ambientais; (3) inquietação social e política e (4) refugiados ambientais (ELLIOTT, 1998:221-230).

Nessa avaliação as questões relativas aos recursos hídricos aparecem como uma das principais fontes de inquietações. Elliott destaca casos, nos quais disputas pelo compartilhamento de águas transfronteiriças ameaçaram a paz regional, utiliza como exemplo os desentendimentos ocorridos na bacia do rio Eufrates, do rio Nilo e do rio Jordão. Ela ainda adverte que problemas relativos a oferta e acesso a água podem potencializar inquietações sociais e política no interior das nações.

A analista mostra-se crítica à abordagem tradicional do tema - ambiente para segurança - apontando sua incoerência, pois se trataria da busca de respostas militares para ameaças não militares. Ela prossegue afirmando que muitos especialistas também criticam tal postura, com base no argumento de que essas políticas são estreitas e se detém muito mais nos efeitos do que nas causa da instabilidade ambiental (ELLIOTT, 1998:231-232).

A autora aponta que as atividades militares contribuem, direta $\mathrm{e}$ indiretamente, para a degradação ambiental das mais variadas formas. Inicia indicando: as estratégias de terra arrasada, o comprometimento dos ecossistemas, a manipulação ou destruição do ambiente para finalidade estratégicas e utiliza os casos da Guerra do Vietnã e o conflito do Golfo (1991) como ilustração. Ainda são citados: o impacto dos veículos militares, gerenciamento de lixo e demanda excessiva de água, o problema das minas terrestres, o alto consumo de energia e recursos naturais, entre outros (ELLIOT, 1998:232-236). 
Elliott (1998) conclui defendendo a adoção de abordagens não-tradicionais, nas quais as atenções devem priorizar a prevenção de escassez dos recursos e a mitigação das causas da degradação ambiental. Nesse sentido, afirma:

Environmental degradation does not respect state borders and states cannot take unilateral action to attain and maintain the security of their own environmental. Tradicional security responses which on military capability cannot ensure the security of the state and its people against environmental degradation. In the face of ecological insecurities, states and peoples cannot be secure unless the ecosystem is secure. Neither is it helpful to identify enemy 'other', whose intent is the violation of territorial and state sovereignty. The enemy, the source of threat, is not the environment but the everyday activies of humans and corporations (ELLIOT, 1998:238).

A segurança ambiental também foi objeto de estudo de Javier Cano, professor de Relações Internacionais da Universidade Autônoma de Barcelona, para ele a diversidade de enfoques reflete $o$ fato de que o tema da segurança na atualidade é abordado por múltiplos atores, dentro de diferentes contextos e com distintas intenções (CANO, 1998:13).

Ao analisar a evolução conceitual do tema, Cano explicita as limitações das abordagens convencionais sobre segurança e passa a defender uma mudança de paradigma. Em suas palavras:

El aumento de la seguridad común de los estados dependerá pois de su capacidad de formular respostas coordinadas y globales a estos problemas. Si la búsqueda de la seguridad ha privilegiado hasta el momento el instrumento militar, tal instrumento no sólo es en ocasiones contrapoducente, sino que se enmarca además en una concepción de la seguridad estática, paradójica incluso en un contexto internacional que pone en cuestión la utilidad d la fuerza armada y muestra la urgencia de otros problemas: el deseo global de progresso y modernización de la actividade humana, que sobrecarga la capacidad de sustento de los sistemas naturales, cuya defensa se 
convierte en 'el más estratégico de todos os sistemas estratégicos' (CANO, 1998:21).

Nessa linha de raciocínio afirma que questões não militares ligadas à segurança devem funcionar como geradoras de uma agenda de segurança alternativa, que além de representar um novo paradigma possuiria novos atores. Essa nova abordagem de segurança abarcaria três grandes temas: segurança humana, segurança ecológica e segurança global, esta entendida como segurança ecológica mais governabilidade local (CANO, 1998:22-26).

O posicionamento do autor fica muito evidente quando ele se refere a segurança ecológica, ele afirma que esse conceito não é uma variante da segurança convencional, mas alternativo, pois não apresenta uma agenda complementar, mas oposta (CANO, 1998:26).

A questão da água surge quando Cano (1998) analisa o impacto de fatores não militares na concepção convencional de segurança; segundo ele, esse tema apresentaria duas vertentes. Uma relativa a conflitos violentos, causados por uma série de processos estreitamente inter-relacionados - crescimento demográfico, aumento da pressão ambiental, privação relativa etc. E outra, referindo-se ao impacto das mudanças ambientais como ameaça direta a sobrevivência e manutenção do status dos indivíduos e, sobretudo, dos Estados. A escassez de água é apontada pelo autor como um dos exemplos do segundo caso (CANO, 1998:19-20). Por nossa conta, ressaltamos que a questão do compartilhamento da água também pode ser encaixada na primeira vertente identificada por Cano.

O trabalho de David Dabelko e Geoffrey Dabelko (1998) apresenta grande consonância com as conclusões de Elliott (1998) e Cano (1998). Nesse trabalho os autores afirmam que atual concepção de segurança - tradicional - foi forjada durante a Guerra Fria e apontam várias limitações dessa abordagem. Entre elas estaria no fato de não contemplarem ameaças não militares. Outra diz respeito à vinculação entre a segurança e o ambiente, eles apontam outros autores que são contra essa vinculação por se tratar de uma institucionalização do tema ambiental, de caráter meramente burocrático. 
Também afirmam que as questões ambientais têm desafiado o domínio da teoria neo-realista nos estudos sobre segurança. Defendem que a segurança ambiental deve ser um paradigma alternativo para enfrentar ameaças de um mundo cada vez mais interdependente e com um meio ambiente cada vez mais degradado. Assim a redefinição do conceito se aproxima cada vez mais a concepções de segurança global ou comum e menos a concepções nacionais (DABELKO e DABELKO, 1998:37).

Ao analisar a relação entre pressão ambiental e conflitos, apresentam argumentos indicando que os problemas ecológicos não seriam necessariamente causadores de conflitos, afirmando que antes disso advém de causas econômicas e políticas (DABELKO e DABELKO, 1998:34). Porém, um pouco mais adiante, reconhecem que questão da escassez de água está entre aquelas que podem desempenhar um importante papel na precipitação de um conflito (DABELKO e DABELKO, 1998:36).

Encontramos uma análise detalhada sobre o tema no já referido trabalho de Le Prestre (2000). Para este analista, semelhantemente a Cano (1998), a segurança ambiental se refere a interrogações e conceitos diversos, segundo as preocupações de cada um dos interessados (LE PRESTRE, 2000:410).

O cientista político afirma que houve uma nítida evolução do conceito de segurança ambiental, pois enquanto a visão tradicional concentrava-se em termos de acesso aos recursos militares importantes, atualmente também há a preocupação "com os impactos das mudanças ambientais sobre o tecido nacional dos países e sobre a estabilidade internacional (LE PRESTRE, 2000:411).

Ele distingue quatro acepções principais às quais o conceito de segurança ambiental pode se referir.

A primeira seria a segurança do meio ambiente, que pode ser entendida como a proteção do meio ambiente em longo prazo, outro aspecto dessa abordagem examina os laços entre a guerra e a proteção ambiental. Ele utiliza o caso da Guerra do Golfo (1991) para ilustrar como o meio ambiente pode vir a ser, ao mesmo tempo, vítima e instrumento de guerra. Também aponta aspectos que vinculam o fenômeno 
da chuva ácida a problemática da segurança nacional (LE PRESTRE, 2000:411419).

A segunda perspectiva seria a segurança dos indivíduos frente aos perigos ambientais, nela o autor distingue vários aspectos: (1) perigos diretos para a saúde das pessoas; (2) a síndrome de Nimby (Not in my backyard ); (3) as catástrofes naturais e (4) as poluições transfronteiriças (LE PRESTRE, 2000:419-422).

Outra abordagem centra-se na segurança dos Estados. Esta conceberia a segurança ambiental como proteção das instituições sociais, política e econômicas nacionais face às mudanças ecológicas externas. Ainda segundo o canadense, as questões que teriam maior importância na visão dos governos são aquelas ligadas: (1) ao acesso a recursos e matérias primas importantes para a economia ou defesa dos Estados e (2) aos impactos das mudanças em escala mundial (LE PRESTRE, 2000:422-423).

O cientista político analisa as relações entre degradação do meio ambiente, penúrias e conflitos internos, que seriam ameaças indiretas dentro da perspectiva da segurança dos Estados. Ele adverte que se cometem equívocos na avaliação das causas de muitos conflitos internos e apresenta exemplos defendendo que em muitos casos a degradação ambiental e a penúria catalisou e não causou tais conflitos (LE PRESTRE, 2000:427-439). Aliás, advertência semelhante as constatações de Dabelko e Dabelko (1998). Vejamos nas palavras do francês, radicado em Quebec:

A importância política da degradação dos recursos renováveis reside não nos laços diretos com conflitos violentos, porém no fato de que diminui a resiliência dos sistemas. Quando sobrevém uma perturbação - climática, econômica, social ou política - o sistema de produção desses recursos afunda. As penúrias poderiam essencialmente desempenhar um papel instrumental ao contribuir para agravar o potencial de conflitos - mas sem os gerar -, ao catalisar as reivindicações de certos de certos grupos ou ao servir de pólos de aglomeração a causas que os ultrapassam (LE PRESTRE, 2000:439). 
A última possibilidade de abordagem apresentada, diz respeito a segurança do sistema internacional, a qual enfoca os riscos de modificações ambientais ou escassez de recursos gerar conflitos interestatais. Nessa abordagem, a maior preocupação seria a de manter a estabilidade da ordem internacional.

Sob esse prisma, são analisados os conflitos concernentes à gestão dos recursos comuns (supostamente comuns, diríamos); como ilustração são avaliados casos de compartilhamento de águas transfronteiriças e de recursos pesqueiros. Os casos relatados são as disputas na bacia do rio Jordão, do rio Eufrates e a Guerra do Flétan, envolvendo Canadá e União Européia sobre a partilha de cardumes na Groelândia. Também analisa os vínculos existentes entre as instabilidades internas e conflitos interestatais, como a questão dos refugiados ambientais (LE PRESTRE, 2000:439-470).

Em suas conclusões sobre o tema Le Prestre (2000) afirma:

Os problemas ambientais se relacionam agora com a alta política internacional em virtude de seus enlaces potenciais com a distribuição do poder econômico e com as questões da segurança nacional. A noção de segurança ambiental é multiforme e seu caráter inovador é discutível. O conceito abrange um conjunto de fenômenos diversos, sendo uns, clássicos, outros mais recentes ou que ganharam dimensões novas. A diversidade de concepções da segurança ambiental reflete duas preocupações distintas. Uns abordam essa noção de um ponto de vista essencialmente analítico. Outros se interessam em maior medida por seu caráter normativo e instrumental (LE PRESTRE, 2000:475).

A perspectiva analítica visaria aprofundar a natureza das variáveis e das relações causais pertinente ao tema. Em outras palavras, nessa perspectiva o foco estaria na busca da resposta da seguinte questão: em que medida problemas ambientais - tais como: a posse de certos recursos, a competição por recursos limitados, a política de gestão ambiental de um outro Estado ou mudanças ecológicas - podem afetar a definição nacional de segurança ou o caráter dos conflitos interestatais? (LE PRESTRE, 2000:475). 
Já a abordagem com um objetivo normativo, estaria centrada na proteção dos ecossistemas e na redefinição das relações entre o homem e a natureza, seria mais defendida por aqueles que se preocupam mais com a segurança ambiental do que com a segurança dos Estados. Essa abordagem buscaria compreender como o Estado poderia mitigar os riscos ambientais (LE PRESTRE, 2000:476). Essa definição se aproxima bastante do uso programático do conceito de segurança ambiental, apresentado na tipologia estabelecida por Cano (1998).

Finalmente, o ponto de vista institucional, que teria surgido em fins dos anos 80 , representaria a visão de militantes, organizações e políticos, que buscavam um aumento da visibilidade política da questão ambiental, ao relacioná-la a um valor tão relevante quanto o da segurança nacional. Nesses sentido, "a degradação do meio ambiente se tornaria um meio, e não a causa, de mobilizações sociais" (LE PRESTRE, 2000:477).

Por seu turno, Ribeiro (2001) abordou a segurança ambiental internacional como aquela que deve ser mantida de modo a não colocar em risco as condições de habitabilidade da humana no planeta. Mesmo como um defensor do aprofundamento dos estudos sobre essa questão, o geógrafo reconhece que a utilização do conceito, ao menos na CNUMAD, "não deixou de cumprir sua função de justificar 'cientificamente' a política externa dos países” (RIBEIRO, 2001:114).

O geógrafo aponta a gestão dos recursos hídricos como um caso emblemático para aqueles que associam militarismo à questão ambiental, salientando que se trata de uma visão estratégica, que admite que os recursos naturais são vitais para a sobrevivência da população de uma unidade política (RIBEIRO, 2001:116).

Após esta revisão sobre o tema, constatamos que, em linhas gerais, há duas perspectivas bastante distintas sobre a questão da segurança ambiental. Uma delas seria a abordagem tradicional, que enfatizaria os problemas ambientais como ameaças as seguranças nacional e internacional; para usarmos a terminologia proposta por Le Prestre (2000), essa seria a perspectiva analítica. Dos autores analisados, Grasa (1994) e Gleick (1994) certamente se enquadram nessa visão. 
A outra corrente de especialistas advoga novas abordagens sobre o conceito. Esses criticam a militarização do tema e afirmam que a ênfase deve ser dada a preservação de recursos naturais e diminuição da degradação ambiental, além defender posturas estatais que encaminhem respostas coordenadas e globais aos desafios ecológicos. Essa seria a perspectiva normativa, claramente apoiada por Elliott (1998), Cano (1998), além de Dabelko e Dabelko (1998).

Le Prestre (2000) não adota um posicionamento explícito sobre qual seria a abordagem mais adequada, o que faz é apontar as limitações de cada uma delas. Sobre a perspectiva analítica, afirma que ela não acrescenta uma nova dimensão a questão, além de ressaltar que relações causais entre problemas ambientais e conflitos ainda carecem de demonstração convincente. Já a abordagem normativa traria consigo grandes imprecisões sobre seus objetivos e a escala de suas preocupações. Quanto a visão instrumental, recebe críticas por se identificar demasiadamente a enfoques estatais e militares, incapazes de promover a cooperação necessária.

Constatamos também que, independentemente da abordagem defendida, todos os autores analisados nesta seção relacionam a questão da escassez e/ou compartilhamento da água com a segurança ambiental, reafirmando a pertinência dessa discussão em nosso trabalho.

No próximo capítulo a temática da segurança ambiental internacional será retomada. Isso ocorrerá quando passarmos a analisar os possíveis desdobramentos - cooperativos ou conflitivos - das interações interestatais relacionadas ao compartilhamento das ATS.

Adiantamos que nossa abordagem se dará sob uma perspectiva analítica e também normativa, para voltarmos a classificação Le Prestre (2000). Em nosso entendimento não se tratam de abordagens excludentes, nem mesmo concorrentes, pois acreditamos que o conhecimento aprofundado relações causais - entre meio ambiente e segurança - são subsídios indispensáveis para as redefinições necessárias na relação homem/meio natural, Estado/meio natural e até mesmo Estado/Estado. Assim como os demais analistas, pretendemos que nosso trabalho contribua para o fomento da paz e da cooperação internacional. 
Por ora, ressaltaremos uma das particularidades que surgem a partir das discussões feitas nessa seção: a suposta oposição entre abordagens não tradicionais de segurança nacional e a noção de soberania nacional. Como demonstraremos, muitos analistas defendem que a visão convencional de soberania deve ser revista frente aos desafios impostos pelas questões ecológicas, que possuem um caráter transnacional e tem na via da cooperação a opção mais adequada. Em função da relevância do conceito de soberania no sistema internacional contemporâneo, entendemos que tal proposição merece reflexão...

\subsection{A questão da soberania nacional}

Antes de avançarmos nas discussões referentes às limitações impostas à soberania nacional, provocadas pelo imperativo da busca da segurança ambiental internacional, torna-se bastante oportuno apresentarmos algumas considerações sobre a origem, o significado e as limitações desse importante conceito.

Em sua significação moderna, o termo surge no final do século $\mathrm{XVI}$, juntamente com o Estado moderno, para afirmar o poder estatal como sujeito único e exclusivo da política. A aplicação deste conceito possibilitou ao príncipe a unificação e concentração de poder, na busca da máxima unidade e coesão sobre um território e uma determinada população (BOBBIO; METTEUCCI; PASQUINO, 2004:1179).

Os escritos de Jean Bodin (1992) são considerados o principal marco teórico da afirmação da soberania. Refletindo a preocupação em consolidar a autoridade do príncipe em um período conturbado ${ }^{15}$, seus estudos defendem a convergência do poder difuso da sociedade medieval para as mãos do monarca, que seria um mero executor das leis e da vontade de Deus. Assim qualquer concessão ou limitação ao exercício dessa autoridade, que não decorresse das leis divinas, deveria ser rechaçada (ALBUQUERQUE, 2001:72-73).

\footnotetext{
${ }^{15}$ Tratava-se do período das guerras dinásticas em solo francês.
} 
O cientista político Le Prestre (2000) aponta o momento em que o conceito de soberania passa a ter relevância internacional:

Sua aceitação internacional remonta à Paz de Westphalia (1648), quando triunfou o princípio cujus regio, ejus religio (já inscrito no Tratado de Augsburg, de 1555) segundo o qual a violência incontrolada das guerras de religião, ou criada pelas ambições nacionais ocultas atrás delas, poderia ser evitada se cada governo reconhecesse o direito exclusivo de outros governos de governar seu reino como quisessem (LE PRESTRE, 2000:127).

Em sua concepção atual, podemos definir soberania, em seu sentido lato, como um conceito político-jurídico que indica o poder de mando de última instância ou autoridade suprema em uma sociedade política (BOBBIO; METTEUCCl; PASQUINO, 2004:1179).

Aplicado no direito e na política internacional o termo designa "a independência ou autonomia de um Estado em relação a outros" (MARSHALL, 1986:1134). Podemos assim, identificar uma dupla face da soberania: a interna e a externa.

Para o pensador alemão MORGENTHAU:

sovereignty is the supreme legal authority of the nation to give and enforce the law a certain territory and, in consequence, independence from the authority of any other nation and equality with it under international law (MORGENTHAU, 1973:313).

Como conseqüência dessa dupla face - interna e externa - surge uma situação aparentemente ambígua: ao contrário do que ocorre nos territórios estatais, não existe uma autoridade suprema controlando o sistema internacional.

F. H. Hinsley (1972) explica que, em teoria, essa dupla face do conceito não é paradoxal e sim sua própria conseqüência lógica. Afinal, o Estado que defende ser livre de limitação e controle dentro de seu território, por pura lógica, está obrigado a reconhecer a mesma liberdade aos demais Estados dentro de seus territórios. Nesse sentido, as implicações internas e externas do conceito de soberania "son la 
expresión extrínseca, el anverso y el reverso de la misma idea" (HINSLEY, 1972:137).

Podemos concluir que é essa unidade dialética que permite uma coerência, ao menos teórica, ao sistema internacional que conhecemos; entendemos que a partir dela os Estados têm seus direitos assegurados, mas, em contrapartida, são levados a assumir determinadas obrigações. Nesse sentido, vejamos os postulados do jurista Hermann Heller:

Únicamente puede ser sujeto de derechos aquel que, al mismo tiempo, puede ser sujeto de obligaciones; ahora bien, as obligaciones internacionales sólo pueden asumirse por las unidades decisorias soberanas, pues únicamente éstas están em aptitud de imponer a sus membros las obligaciones contraídas sin la intervencion de otra unidad decisoria, pudiendo llegar, en caso de necesidad, a la reforma de su constitución (HELLER, 1995:263).

Em nosso entendimento, devemos ressaltar a diferença existente entre a dimensão jurídica do conceito e sua dimensão política. Estamos convictos que tal distinção é imprescindível nas análises sobre o tema.

Defendemos que, do ponto de vista jurídico, todos os Estados são igualmente soberanos, isto porque cada um deles é a autoridade máxima em sua jurisdição e possui o direito fundamental de decidir quanto a se submeter ou não a acordos internacionais. Sob esse viés, todos os Estados são iguais, independentemente de qualquer fator geográfico, político, militar ou econômico. Nesse sentido, "a soberania é uma questão de status e não de poder", para utilizarmos uma expressão de Le Prestre (2000).

Partindo do ângulo da política - da geopolítica, diríamos - constatamos que os fatores que influenciam no balanço de poder internacional transforma a igualdade jurídica em ficção. Como a realidade demonstra, os Estados muitas vezes são coagidos, através da dissuasão ou coerção, a tomarem decisões que implicam em restrições a sua soberania interna, inclusive territorial. Assim, a capacidade de independência na cena internacional, em grande parte dos casos, varia proporcionalmente ao poder político, econômico, tecnológico e militar, fatores que 
são por muitas vezes condicionados aos atributos territoriais. Portanto, concluímos que é sob a dimensão política do conceito de soberania que a geografia pode apresentar sua contribuição.

Enfatizamos que a questão da segurança ambiental multiplica seu grau de complexidade quando abordamos seu caráter transnacional. Considerando-se que os problemas ambientais decorrem de processos antrópicos e naturais, que muitas vezes têm um alcance que transborda os limites fronteiriços dos Estados, inúmeros desafios surgem na busca por essa concepção de segurança. As dificuldades e controvérsias se materializam quando estão em questão: (1) a regulamentação de impactos ambientais transfronteiriços ou globais, como o caso da chuva ácida e do aumento do efeito estufa; (2) a gestão de áreas comuns, como os oceanos e a Antártica; ou ainda, (3) a concorrência por recursos naturais e ecossistemas compartilhados, como no caso das bacias hidrográficas internacionais.

Frente a tais desafios, as iniciativas cooperativas têm se apresentado como a forma de encaminhamento mais pertinente. Para alguns, esse tipo de relação interestatal representaria uma pressão direta à noção tradicional de soberania. Isso porque nessas situações são acordadas decisões que interferem diretamente nas políticas territoriais dos Estados, limitando seu poder, ao condicionar a gestão e a apropriação de seus recursos a fatores externos.

O relatório Brundtland (CMMAD, 1988) já explicita a concorrência entre a concepção clássica de soberania e os esforços cooperativos na busca da sustentabilidade e da segurança ambiental internacional:

As formas tradicionais de soberania nacional são constantemente desafiadas pelas realidades de interdependência econômica e ecológica. Isso é especialmente verdadeiro nos ecossistemas compartilhados e nas "áreas comuns do globo" - as partes do planeta que ficam fora das jurisdições nacionais. Nesse caso, só se pode assegurar o desenvolvimento sustentável através da cooperação internacional e administração de interesses comuns. Mas o que está em jogo não é só o desenvolvimento sustentável dos ecossistemas compartilhados e das áreas comuns, e sim o de todas 
as nações que para se desenvolverem dependem em maior ou menor grau de sua administração racional (CMMAD, 1988:293). [0 grifo é nosso]

Frente a problemas de tal natureza, alguns analistas apontam para uma suposta caducidade da concepção clássica de soberania nacional. Trata-se, normalmente, daqueles que defendem abordagens não tradicionais sobre a concepção de segurança; como vimos, são aqueles preocupados em fornecer segurança ao meio ambiente e que acreditam em respostas interestatais coordenadas, como único caminho perante tais problemas.

Constatamos tal posicionamento em um dos argumentos utilizados por CANO (1998) em defesa do conceito de segurança ecológica:

El punto de vista común a los trabajos que otorgan al concepto esta dimensión alternativa es la emergencia de los factores medioambientales - en sentido amplio englobando el medio natural y el humano - como temas que limitam radicalmente la soberania del estado y cuestionan la conveniencia de la orientación tradicional, político-militar, de la seguridad nacional (CANO, 1998: 25).

Concepção semelhante pode ser extraída das críticas que Dabelko e Dabelko (1998) fazem às abordagens realistas sobre a questão ambiental:

El realismo induce a los estudiosos a aprejutar las cuestiones medioambientales en una estructura de conceptos que incluye estado, soberania, territorio, interesses nacionales y equilibrio de poder, pero la degradación medioambiental produce una complejidad que es insuficientemente explicada por las teorías de los actores estatales racionalmente unitários (DABELKO e DABELKO, 1998:42).

Após apresentarem casos para ilustrar as relações entre degradação ambiental e conflitos, completam: "Estos fenomenos transfronteirizos cuestionan la primacía del estado soberano como actor en la salvaguardia de territorio, poblaciones e intereses" (DABELKO e DABELKO, 1998:42). 
A norueguesa Gro Brundtland ao defender uma maior interdependência e cooperação internacional frente aos desafios impostos pelos riscos ecológicos, explicava como deveria ser entendido o princípio da soberania no atual contexto das relações internacionais:

A verdadeira soberania, num mundo que se assemelha a um condomínio, onde todos precisam estabelecer entendimento e acordos recíprocos, sob pena de a casa comum perecer na desordem, consiste na integração de esforços em prol do desenvolvimento sustentado da Humanidade (Jornal da Tarde, 03/02/90 p.10, apud MIYAMOTO, 1992:24).

Le Prestre (2000) acredita que acompanhamos atualmente dois movimentos inversos, que seriam: a consolidação e a erosão da capacidade dos Estados em exercer sua soberania. Entre os desafios a salvaguarda da soberania apontados, três possuem relação com questões ambientais. Seriam eles:

(1) interdependências econômicas e ecológicas entre Estados;(...);

(2) emergência de atores e movimentos transnacionais: OIGs, ONGs, ETNs, nações/etnias, que formam coalizões transnacionais em favor de um mesmo objetivo ou exercem pressões sobre governos; (...); (3) desenvolvimento de novos direitos universais, que se manifesta, por exemplo, na identificação dos problemas ambientais com os problemas da pessoa humana" (LE PRESTRE, 2000:131).

Considerando-se a importante face jurídica do conceito de soberania e os objetivos desse capítulo, utilizaremos o diálogo com o Direito Internacional do Meio Ambiente como subsídio à nossa análise. Como poderemos constatar, a questão da soberania nacional sempre esteve no cerne das discussões deste ramo do saber jurídico, desde de seu surgimento como tal.

O jurista Guido Soares ${ }^{16}$ (2001) afirma que caso da Fundição Trail (Trail Smelter) é apontado por grande parte da doutrina como a primeira manifestação

\footnotetext{
${ }^{16}$ O Prof. Dr. Guido Fernando Silva Soares foi professor titular da Faculdade de Direito do Largo São Francisco e tornou -se uma das maiores autoridades nacionais no campo do direito internacional público e meio ambiente.
} 
formal do Direito Internacional do Meio Ambiente. Resolvida definitivamente, em 1941, por um tribunal arbitral, tratava-se de uma demanda jurídica contra o Canadá apresentada pelos EUA, referente a danos causados pela poluição transfronteiriça. A parte principal da sentença estabelece:

Nenhum Estado tem o direito de usar ou de permitir o uso de seu território de tal modo, que cause dano em razão do lançamento de emanações no, ou até o, território de outro" (Anuario de la Comisión de Derecho Internacional, Nações Unidas, 1978. v.2, p. 198; apud SOARES, 2001:44).

O jurista esclarece que a doutrina internacionalista tem considerado o importante princípio 21 da Declaração de Estocolmo "como cristalização de uma das normas fundamentais do Direito Internacional do Meio Ambiente, conforme declarada por ocasião do julgamento do caso da Fundição Trail" (SOARES, 2001:44). Tal princípio é explícito quanto a salvaguarda da soberania interna dos Estados:

Os Estados têm, de acordo com a Carta das Nações Unidas e os princípios do direito internacional, o direito soberano de explorar seus próprios recursos, conforme suas próprias políticas relativas ao meio ambiente, e a responsabilidade de assegurar que tais atividades exercidas dentre de sua jurisdição, não causem danos ao meio ambiente de outros Estados ou a áreas fora dos limites da jurisdição nacional (Declaração de Estocolmo, 1972; apud SOARES, 2001 anexo C).

A partir de então, o referido princípio foi retomado em todas as declarações e na maioria dos tratados ambientais (LE PRESTRE, 2000:127). A seguir destacaremos alguns desses documentos.

Um deles foi a Declaração do Rio sobre Meio Ambiente e Desenvolvimento, que em seu $2^{\circ}$ princípio, reafirmou, praticamente nos mesmos termos, o princípio 21

Sua principal obra sobre o assunto (SOARES, 2001) é resultado de sua tese apresentada àquela Faculdade para obtenção de sua titularidade. 
da Declaração de Estocolmo. No documento de 1992, foram acrescentadas as seguintes expressões: (1) e de desenvolvimento, após políticas relativas ao meio ambiente, além de (2) ou controle, após sob sua jurisdição.

Além de documentos internacionais não vinculantes, denominados pelo direito internacional público como soft law, também encontramos a salvaguarda da soberania territorial dos Estados na Convenção sobre Diversidade Biológica (SÃO PAULO, 1997). Em seu $3^{\circ}$ artigo, encontra-se transcrito integralmente ${ }^{17}$ o princípio $2^{\circ}$ da Declaração do Rio sobre Meio Ambiente e Desenvolvimento.

Enquanto muitos analistas entendem os postulados desse princípio como uma clara reafirmação da soberania dos Estados, Le Prestre (2000) os entende como um elemento de relativização do exercício da soberania. Em seus argumentos, afirma que a decisão não permite os Estados explorarem seus recursos sem ter em conta seus vizinhos (LE PRESTRE, 2000:129). Entendemos que a limitação identificada pelo francês enfatiza isoladamente à face externa do princípio da soberania, como podemos depreender de sua leitura, o texto é bastante explícito quanto à garantia da soberania territorial. Além disso, conforme nos ensina Hinsley (1972), essa limitação externa da soberania é lógica e intrínseca ao princípio.

Outro exemplo da tendência de reafirmação da soberania em documentos internacionais, está no fato do Conselho de Administração do PNUMA, ter tomado a iniciativa de precisar a definição clássica do desenvolvimento sustentável contida no Relatório Brundtland (CMMAD, 1988), que ficou com a seguinte redação:

O desenvolvimento durável [sustentável] é uma forma de desenvolvimento que responde às necessidades atuais sem comprometer a capacidade das gerações futuras a satisfazer suas necessidades e que em nenhum caso, prejudica sua soberania nacional (PNUMA/CG.15/12, Anexo 1, p. 123; apud LE PRESTRE, 2000:131).

\footnotetext{
17 "Os Estados, em conformidade com a Carta das Nações Unidas e com os princípios do Direito Internacional, têm o direito soberano de explorar seus próprios recursos segundo suas políticas ambientais, e a responsabilidade de assegurar que atividades sob sua jurisdição ao controle não causes dano ao meio ambiente de outros Estados ou de áreas além dos limites da jurisdição nacional" (SÃO PAULO, 1997: 17).
} 
Em um de seus últimos trabalhos, Soares (2002) apresenta a "proteção internacional do meio ambiente" como um dos dois grandes temas do direito internaciona $\left.\right|^{18}$. Em certo trecho, o jurista também demonstra a complexidade que envolve as questões ambientais, quando estas atingem a escala transnacional:

Por sua própria natureza, certos fenômenos biológicos ou físicos localizados dentro de um espaço geográfico submetido à soberania de um Estado exigem regulamentação internacional, seja porque, em sua unicidade, estendem-se sobre a geografia política de vários países, seja porque os fenômenos a serem regulados somente poderão sê-lo com a intervenção de normas internacionais. $\mathrm{Na}$ verdade, em sua caracterização moderna o meio ambiente é um fenômeno que desconhece fronteiras (...) (SOARES, 2002:407-408).

Nesta obra o autor reserva um capítulo para tratar dos "espaços sob soberanias dos Estados e espaços internacionais comuns", no qual analisa as principais questões que surgiram nas relações internacionais a partir da consolidação do Estado moderno. Constatamos que todos os tópicos apontados envolvem questões de soberania territorial. Entre elas, surgem aquelas relacionadas ao caráter transfronteiriço dos problemas ambientais:

as limitações ao exercício do poder no interior daqueles espaços, de maneira que tal exercício não venha a interferir com os espaços reservados a outros Estados, ou colocados sob a égide das normas internacionais (e, nesse ponto, as modernas discussões internacionais são as mais candentes, sobretudo no que respeita aos problemas relacionados com as poluições transfronteiriças, ou aos efeitos da ação isolada e soberana dos Estados, no clima do planeta, ou na camada de ozônio que envolve a atmosfera terrestre); e as questões relacionadas com fenômenos que desconhecem fronteiras, como (...) o fenômeno já citado, da poluição transfronteiriça ou da degradação do meio ambiente dos espaços não submetidos a uma soberania estatal (SOARES, 2002:291-292).

\footnotetext{
${ }^{18} \mathrm{O}$ outro seria a "proteção internacional da pessoa humana" em suas três vertentes: direitos humanos, direitos dos refugiados e direito de asilo.
} 
Em outro trabalho (SOARES, 1993), após fazer considerações sobre os espaços internacionais, o jurista é enfático ao apontar a incongruência desta visão tradicional de soberania dos Estados frente as realidades hodiernas. Em suas palavras:

\begin{abstract}
Mal haveria como compatibilizar às realidades descritas a concepção passadista de que no território de um Estado não se admite qualquer ingerência, uma vez que o único poder possível é o do governo do Estado (a concepção clássica de soberania). Admitindo tal concepção restaria - em relação ao território do Estado, considerado um espaço compacto - a uma imagem de um queijo suíço onde a soberania dos Estados estaria rodeada de vazios criados pela realidade. $\mathrm{Na}$ verdade, esta realidade é implacável: Estados poderosos, potências médias ou Estados pequenos, todos estão sofrendo crescentes limitações às suas soberanias, em benefício da convivência e da paz internacionais e, em particular, nos dias atuais, em benefício da preservação da higidez do meio ambiente, que pertence a todos nós e às gerações futuras" (SOARES, 1993:34).
\end{abstract}

Ao analisarmos os postulados do jurista, surge-nos uma grande inquietação: será que tais limitações à soberania nacional incidem sobre os Estados em mesmo grau? Ou será que os Estados poderosos conseguem garantir uma influência externa menor? A partir daí, ainda questionamos: será que a tese da relativização da soberania é aceita por todos os Estados e em todas as situações? Ou será que os Estados tomam decisões distintas de acordo com seus interesses nacionais? Tais respostas requerem que voltemos à luz da geografia política e da ciência política.

Como já demonstrado na primeira seção desse capítulo, Ribeiro (2001) é enfático ao afirmar que a atitude predominante dos Estados na ordem ambiental internacional é a de garantir seus interesses e salvaguardar sua soberania. Seu trabalho é rico em exemplos, dos quais destacamos: a postura contrária dos EUA frente à Convenção de Biodiversidade e a oposição dos principais países exportadores de petróleo às decisões da Convenção de Mudanças Climáticas. 
O trabalho Miyamoto (1992) deixa claro que a questão ambiental na escala internacional, não pode ser analisada fora do contexto da ordem internacional vigente. Nesse mesmo sentido, a ordem ambiental refletiria a ordem mais ampla. $E$ quanto à lógica desta o cientista político é bastante explícito:

Concretamente verifica-se uma distância insuperável entre o discurso e a prática das grandes nações frente aos demais países, interferindo em qualquer lugar do mundo e advogando a tese da soberania compartilhada quando seus interesses forem de alguma forma afetados (MIYAMOTO, 1992:16).

Por outro lado, Miyamoto (1992) também ressalta que a defesa da soberania absoluta - concepção clássica - também tem servido de subterfúgio para as políticas ambientais incompetentes dos países pobres. Para ilustrar, cita ocasiões em que o Brasil utilizou o "escudo" da soberania frente às pressões internacionais de cunho ambientais.

O jurista e Embaixador Geraldo Nascimento e Silva (1995) aponta que, às vésperas da Conferência do Rio, alguns países do Norte articularam esforços para evitar a referência ao direito soberano, fato que suscitou justificada reação dos países do Sul. Ele explica que a reboque dessa teoria - de supressão do direito soberano - buscava-se justificar a tese do dever de ingerência, a ser exercido individual ou coletivamente, pelos Estados (SILVA, 1995:52).

Também como desdobramento dessa tese houve iniciativas favoráveis à criação de um organismo supranacional, bem como sanções, contra países que apresentassem má conduta em matéria de proteção ambiental. Sobre tais iniciativas, Silva (1995) pondera que:

o chamado dever de ingerência, bem mais drástico do que o direito de ingerência, está ligado à noção de enforcement, ou seja, de execução em caso de dano ambiental (...). Considerando que os principais danos ao meio ambiente são atribuíveis às potências industriais, a dúvida que existe consiste em saber se, na hipótese de má conduta pelos EUA, Grã-Bretanha, Alemanha ou Rússia, uma entidade supranacional teria poderes para julgar e punir um dos 
países citados. Daí o empenho dos países mais débeis em insistir, durante a Conferência do Rio e durante os trabalhos preparatórios, que a referência ao direito soberano de explorar os seus recursos naturais em conformidade com sua política ambiental fosse mantida (SILVA, 1995:52-53).

As constatações Silva (1995) são suficientes para demonstrar os riscos e interesses implícitos nas postulações que defendem a flexibilização do conceito de soberania, caso elas sejam empregadas de forma acrítica e distorcida. Nesse sentido, Miyamoto (1992) alerta para o abismo existente entre o discurso e a prática das grandes nações, que defendem a soberania compartilhada, desde que não seja em seus respectivos territórios; enquanto Ribeiro (2001) enfatiza a prevalência da defesa da soberania nacional na OAI.

Procuramos até este ponto, demonstrar a relevância dos debates que envolvem a questão da soberania nacional para a compreensão do mundo contemporâneo. Acreditamos ter deixado claro que se trata de um princípio basilar para o funcionamento do sistema internacional e que, em sua faceta externa, garante direitos aos Estados, mas por outro lado implica no fato de que estes devem assumir também deveres.

Esse caráter basilar é identificado quando interpretamos a ordem ambiental internacional, visto que esse princípio está salvaguardado em quase todos os Tratados e Convenções ambientais. Além disso, é aplicação de sua faceta interna que pode garantir o sucesso objetivado em um acordo ambiental internacional.

Ao retomarmos o tema da segurança ambiental internacional, constatamos que muitos analistas acreditam que as ameaças geradas pelo caráter transnacional dos problemas ecológicos só podem ser enfrentadas a partir de soluções cooperativas, o que implicaria em uma flexibilização da concepção tradicional soberania - que seria aquela o que Miyamoto (1992) denomina de soberania absoluta. 
No diálogo com o direito internacional do meio ambiente encontramos constatações semelhantes. Afinal os estudos de Soares (1993 e 2002), afirmam que a concepção clássica de soberania, não dá conta da realidade do atual cenário internacional, especialmente no que diz respeito às questões ambientais. Porém, o jurista Silva (1995) aponta que a vulgarização dessa tese pode alimentar os interesses dos países do Norte.

Ademais, a análise de Ribeiro (2001) constata que na ordem ambiental internacional os Estados procuram salvaguardar seus interesses nacionais e, por extensão, sua soberania, a cada rodada de negociações ambientais.

Da mesma forma, as constatações de Miyamoto (1992) indicam um predomínio de posturas realistas dos Estados, nas quais o princípio da soberania é utilizado segundo os interesses nacionais.

Por nosso turno concordamos com aqueles que defendem as soluções cooperativas - que supostamente implicariam na flexibilização da soberania - como as melhores, certamente as únicas, soluções para os problemas ambientais transnacionais. Porém, não podemos fechar os olhos para como as coisas realmente são: nas práticas estatais na ordem ambiental internacional têm prevalecido a salvaguarda da soberania e dos interesses nacionais.

Inspirados em Hinsley (1972) e Heller (1995), entendemos que as obrigações advindas da adesão a um Tratado internacional não ferem o princípio de soberania, desde que ela seja feita em condições de eqüidade com as demais Partes e que tal adesão não tenha sido fruto de uma dissuasão ou coerção externa de qualquer natureza. Dito em outras palavras: trata-se de uma decisão soberana aquela que tenha sido fruto exclusivo da autoridade estatal.

Nesse sentido, acrescentamos ainda: se todos os Estados adotassem uma postura estritamente hobbesiana, que levaria a defesa da soberania nacional às últimas conseqüências, não existiriam as relações internacionais, como as conhecemos.

Ainda nesse trabalho teremos a oportunidade de avaliar a validade do principio da soberania nacional utilizando um caso concreto: as relações interestatais relativas ao compartilhamento das ATS na Bacia do Rio Danúbio. 
Buscamos nesse capítulo iniciar a discussão sobre os principais aspectos teóricos que permearão nosso trabalho. O próximo passo será analisar como os desafios relacionados a segurança ambiental internacional e a soberania nacional se materializam na questão das águas transfronteiriças superficiais. Além disso, apresentaremos as principais iniciativas internacionais referentes ao compartilhamento desses recursos como um subsistema em construção da OAI. 


\section{CAPÍTULO 3 - A geopolítica das águas transfronteiriças superficiais}

Neste capítulo abordaremos a problemática do compartilhamento das águas transfronteiriças superficiais (ATS), ressaltando os fatores geográficos e políticos envolvidos na questão. Iniciaremos essa tarefa, apresentando os principais desafios inerentes às áreas drenadas por tais recursos, ou seja, às bacias hidrográficas transfronteiriças. A partir da avaliação da distribuição geográfica desses sistemas hidrográficos, demonstraremos que o tema afeta diretamente a grande maioria dos Estados soberanos. Ao analisarmos a dinâmica de funcionamento dessas bacias, identificaremos os principais impactos potenciais, enfatizando que a competição imposta pelo caráter transnacional da questão a coloca como uma materialização da discussão em torno do princípio de soberania nacional.

Também nesse capítulo, estabeleceremos as relações entre o compartilhamento das ATS e os riscos à segurança ambiental internacional. Nesse sentido, avaliaremos o potencial conflitivo envolvido na problemática, buscando identificar seus fatores determinantes. Ainda demonstraremos, apoiados em estudos do projeto Basins at Risk, realizados sob os auspícios da Oregon State University, que apesar da prevalência de interações estatais cooperativas, não podemos descartar a hipótese de que disputas por tais recursos podem deteriorar as relações entre Estados.

Por fim, apresentaremos o compartilhamento das ATS como um subsistema da ordem ambiental internacional que se encontra em evolução. Avaliaremos a institucionalização das discussões internacionais ocorridas sob os auspícios da ONU, assim como as iniciativas para a regulamentação internacional da gestão desses recursos.

Ao discutirmos tais temas pretendemos identificar as variáveis necessárias para analisarmos a questão das águas transfronteiriças na bacia do rio Danúbio, tarefa que será realizada no capítulo 4 . 


\subsection{As bacias hidrográficas transfronteiriças}

A gestão internacional dos recursos hídricos é, sem sombra de dúvida, um dos temas mais relevantes entre aqueles relacionados a sustentabilidade de nosso planeta. Afinal, a questão envolve uma fonte vital para a manutenção da vida e para o desenvolvimento sócio-econômico de povos e Estados. Além disso, conforme foi demonstrado no capítulo 1, sua crescente escassez relativa vem causando grandes preocupações em todos os quadrantes do globo.

Consideráveis parcelas dos recursos de água doce escoam sobre bacias hidrográficas transfronteiriças (BHT) e são denominadas neste trabalho como águas transfronteiriças superficiais (ATS).

Por sua vez, bacia hidrográfica será entendida como a área de contribuição hidrológica (incluindo águas superficiais e subterrâneas) de um fluxo hidrográfico de $1^{a}$ ordem; este, por sua vez, será definido por sua saída para o oceano ou para um terminal fechado - lago ou mar. Assim, denominaremos de bacias hidrográficas transfronteiriças aquelas que possuem tributários perenes que cruzam ou coincidem com os limites políticos de dois ou mais Estados (cf WOLF et al., 1999).

Estima-se que $60 \%$ do fluxo hidrográfico global circulam em bacias com tais particularidades geográficas (UNEP, 2002:2). Quando focamos os principais rios do mundo, a contribuição das ATS é ainda maior. O estudo de I. Shiklomanov (1993) listou os vinte e cinco maiores rios do mundo, estimando para eles uma vazão de $19.200 \mathrm{~km}^{3}$, o que representa pouco menos da metade do escoamento mundial total. Suas conclusões demonstram que $87 \%$ do volume desses vinte e cinco rios - ou $16.700 \mathrm{~km}^{3}$ - são encontrados em vinte deles, que são internacionais (WOLF et al., 1999).

Os dados da TABELA 3.1 contribuem para a ilustrar a importância quantitativa das ATS, afinal entre os dez rios mais volumosos do planeta, apenas dois - Yang Tze e Lena - não são internacionais. 
Tabela 3.1 - Maiores rios do globo, segundo descargas médias anuais

\begin{tabular}{|c|c|c|c|c|}
\hline & Rio & $\begin{array}{l}\text { Descarga } \\
\text { média } \\
\text { anual } \\
\left(\mathrm{m}^{3} / \mathrm{seg}\right)\end{array}$ & $\begin{array}{c}\text { Volume } \\
\left(\mathbf{k m}^{3}\right)\end{array}$ & País (es) \\
\hline $1^{0}$ & Amazonas & 155.432 & 4.901 & $\begin{array}{l}\text { Brasil, Peru, Bolívia, Colômbia, } \\
\text { Equador, Venezuela, Guiana, } \\
\text { Suriname, Guiana Francesa. }\end{array}$ \\
\hline $2^{0}$ & Congo/Zaire & 40.250 & 1.296 & $\begin{array}{l}\text { Rep. Democrática do Congo, } \\
\text { Rep. Centro-Africana, Angola, } \\
\text { Congo, Zâmbia, Tanzânia, } \\
\text { Camarões, Burundi, Ruanda, } \\
\text { Sudão, Gabão Malawi, Uganda. }\end{array}$ \\
\hline $3^{\circ}$ & Orinoco & 31.061 & 980 & Venezuela, Colômbia, Brasil. \\
\hline $4^{\circ}$ & Yang Tze & 25.032 & 789 & China \\
\hline $5^{\circ}$ & Brahmaputra & 19.674 & 620 & Índia, China, Nepal \\
\hline $6^{\circ}$ & Jenesej/Yenisei & 17.847 & 563 & Federação Russa, Mongólia \\
\hline $7^{\circ}$ & Lena & 16.662 & 524 & Federação Russa \\
\hline $8^{\circ}$ & Prata & 16.595 & 516 & $\begin{array}{l}\text { Brasil, Argentina, Paraguai, } \\
\text { Bolívia, Uruguai. }\end{array}$ \\
\hline $9^{\circ}$ & Mississipi & 14.703 & 464 & $\begin{array}{l}\text { Estados Unidos da América, } \\
\text { Canadá. }\end{array}$ \\
\hline $10^{\circ}$ & $\mathrm{Ob}$ & 12.504 & 394 & $\begin{array}{l}\text { Federação Russa, Cazaquistão, } \\
\text { China, Mongólia. }\end{array}$ \\
\hline
\end{tabular}

Fonte: Unesco, 2003

Outro aspecto contundente está na abrangência das BHT sobre a superfície das terras emersas. O MAPA 3.1 destaca essas bacias no Globo, enquanto a TABELA 3.2 identifica aquelas mais extensas.

A área total das BHT - representada no MAPA 3.1 - corresponde $45,3 \%$ da superfície terrestre (excluindo-se a Antártica) e acolhem cerca de $40 \%$ da população mundial (UNEP, 2002:2). Na escala regional, notamos que tais bacias se destacam especialmente na América do Sul, África e Europa onde superam $50 \%$ das áreas desses continentes ${ }^{19}$.

\footnotetext{
${ }^{19}$ Em relação às superfícies continentais tais bacias correspondem a: 62 por cento na África, 39 por cento na Ásia, 54 por cento na Europa, 35 por cento na América do Norte e 60 por cento na América do Sul (WOLF et al, 1999).
} 


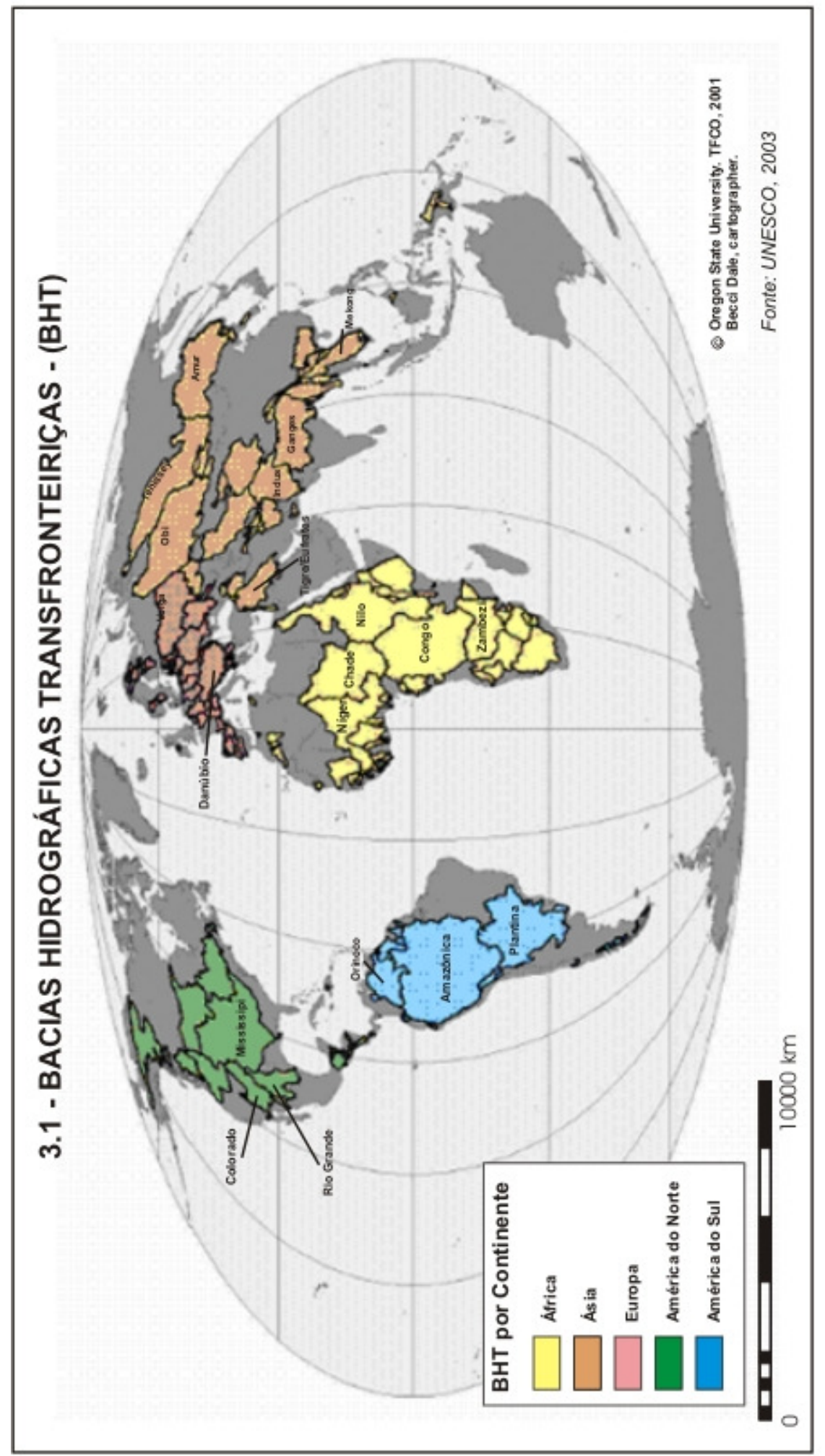


Tabela 3.2 - As maiores BHT do globo

\begin{tabular}{|c|c|c|c|}
\hline & Rio/lago principal & $\begin{array}{l}\text { Área } \\
\left(\mathrm{km}^{2}\right)\end{array}$ & Países \\
\hline $1^{a}$ & Amazonas & 5.883 .400 & $\begin{array}{l}\text { Brasil, Peru, Bolívia, Colômbia, Equador, } \\
\text { Venezuela, Guiana, Suriname, Guiana } \\
\text { Francesa. }\end{array}$ \\
\hline $2^{a}$ & Congo/Zaire & 3.691 .000 & $\begin{array}{l}\text { República Democrática do Congo, República } \\
\text { Centro-Africana, Angola, Congo, Zâmbia, } \\
\text { Tanzânia, Camarões, Burundi, Ruanda, Sudão, } \\
\text { Gabão, Malawi, Uganda. }\end{array}$ \\
\hline $3^{a}$ & Mississipi & 3.226 .300 & Estados Unidos da América, Canadá. \\
\hline $4^{a}$ & Nilo & 3.031 .700 & $\begin{array}{l}\text { Sudão, Etiópia, Egito, Uganda, Tanzânia, Kênia, } \\
\text { República Democrática do Congo, Ruanda, } \\
\text { Burundi, Eritréia, Rep. Centro-Africana. }\end{array}$ \\
\hline $5^{a}$ & Prata & 2.954 .500 & Brasil, Argentina, Paraguai, Bolívia, Uruguai. \\
\hline $6^{\mathrm{a}}$ & $\mathrm{Ob}$ & 2.950 .800 & $\begin{array}{l}\text { Federação Russa, Cazaquistão, China, } \\
\text { Mongólia. }\end{array}$ \\
\hline $7^{a}$ & Jenisej/Yenisey & 2.557 .800 & Federação Russa, Mongólia. \\
\hline $8^{a}$ & Lago Chade & 2.388 .700 & $\begin{array}{l}\text { Chade, Niger, República Centro-Africana, } \\
\text { Nigéria, Argélia, Sudão, Camarões, Líbia. }\end{array}$ \\
\hline $9^{a}$ & Níger & 2.113 .200 & $\begin{array}{l}\text { Nigéria, Mali, Níger, Argélia, Guiné, Camarões, } \\
\text { Burkina Fasso, Benin, Costa do Marfim, Chade, } \\
\text { Serra Leoa. }\end{array}$ \\
\hline $10^{\mathrm{a}}$ & Amur & 2.085 .900 & $\begin{array}{l}\text { Federação Russa, China, Mongólia, Coréia do } \\
\text { Norte. }\end{array}$ \\
\hline
\end{tabular}

Fonte: UNESCO, 2003

A complexidade e relevância do tema se completam quando constatamos o grande número de BHT e de Estados diretamente localizados nelas. Atualmente, são 
conhecidas 263 bacias internacionais e 145 Estados que possuem seus territórios nesses sistemas hidrográficos (UNESCO, 2003:303; UNEP, 2002:2).

A TABELA 3.3 apresenta a evolução do número dessas bacias nas últimas décadas, além de apontar a distribuição geográfica de tais sistemas.

\section{Tabela 3.3 - Número de BHT}

\begin{tabular}{|l|c|c|}
\hline Continente & $\mathbf{1 9 7 8}$ & $\mathbf{2 0 0 2}$ \\
\hline África & 57 & 59 \\
\hline Ásia & 40 & 57 \\
\hline Europa & 48 & 69 \\
\hline América do Norte & 33 & 40 \\
\hline América do Sul & 36 & 38 \\
\hline Total & 214 & 263 \\
\hline
\end{tabular}

Fontes: Wolf et al. 1999 e UNEP, 2002

A TABELA 3.3 nos permite constatar que, ao longo do referido período, houve um sensível aumento no número de $\mathrm{BHT}$, além do fato de que o continente europeu passou a ocupar a posição de principal detentor dessas bacias. Tais mudanças decorrem, essencialmente, de dois fatores: (1) a internacionalização de bacias hidrográficas nacionais, devido a mudanças geopolíticas acarretadas pela fragmentação de Estados, como lugoslávia e URSS (União das Repúblicas Socialistas Soviéticas); e (2) a descoberta de novas bacias internacionais, em função de avanços tecnológicos nas áreas de sensoriamento remoto e cartografia (Wolf et al., 1999).

A TABELA 3.4 comprova que uma maioria expressiva dos Estados soberanos - cerca de dois terços - possui seus territórios inseridos em bacias hidrográficas transfronteiriças. Além disso, nesse universo de 145 países, nota-se um amplo predomínio de casos nos quais as áreas sob tais condições representam a maior parte do território nacional. Como podemos constatar, são 92 países, que possuem mais de $50 \%$ de seu território em bacias desse tipo. Assim, inferimos que não são poucas, nem isoladas, as preocupações dos governantes frente a esse tema, uma 
vez que territórios com essas particularidades terão sua gestão influenciada por fatores externos às fronteiras nacionais, conforme demonstraremos adiante.

\section{Tabela 3.4}

\section{Número de países, segundo porcentagem do território em BHT}

\begin{tabular}{|c|c|}
\hline Número de países & Área dentro de BHTs \\
\hline 39 & $90-100 \%$ \\
\hline 11 & $80-90 \%$ \\
\hline 14 & $70-80 \%$ \\
\hline 11 & $60-70 \%$ \\
\hline 17 & $50-60 \%$ \\
\hline 10 & $40-50 \%$ \\
\hline 10 & $30-40 \%$ \\
\hline 13 & $20-30 \%$ \\
\hline 11 & $10-20 \%$ \\
\hline Total: 145 & $0.01 \%-10 \%$ \\
\hline
\end{tabular}

Fonte: Wolf et al, 1999

Sob esse aspecto, não faltam casos extremos, já que 21 países possuem a totalidade de seu território em BHT, enquanto outros doze possuem mais de $95 \%$ de sua área sob essas circunstâncias geográficas. Essa situação não se restringe a países de pequena extensão, como Andorra e Liechtenstein, mas também incide em países de maior extensão como Hungria e Eslováquia, que serão tratados em particular no próximo capítulo.

Ainda podemos visualizar os dilemas relacionados ao gerenciamento das BHT observando o número de Estados soberanos que compartilham cada uma dessas bacias. Cerca de um terço do total delas são divididas por mais de dois países, destacando-se dezenove bacias que são compartilhadas por cinco ou mais países.

Considerando-se esse fator de complexidade, o caso mais delicado é o da bacia do Rio Danúbio, que possui 17 nações co-ribeirinhas. Esta particularidade foi 
um dos aspectos decisivos para escolhermos essa bacia hidrográfica como foco de nossa investigação.

Destacam-se também cinco bacias - Congo, Níger, Nilo, Reno e Zambeze que são compartilhadas entre nove e onze países; enquanto outras treze Amazonas, Ganges-Brahmaputra-Meghna, Lago Chade, Tarim, Mar de Aral, Jordão, Kura-Araks, Mekong, Tigre-Eufrates, Volga, Prata, Neman e Vistula - têm entre cinco e oito países co-ribeirinhos (UNESCO, 2003:303).

Acreditamos que as coletâneas de dados apresentadas acima são suficientes para demonstrar a dimensão que o compartilhamento das ATS possui nas relações internacionais dos dias atuais. Entendemos que as circunstâncias geográficas e políticas que envolvem esses recursos atribuem à questão um elevado valor estratégico.

Certamente é devido a sua relevância, que acompanhamos na literatura acadêmica internacional uma crescente produção de trabalhos sobre o assunto. Por outro lado, entendemos que o tema ainda não alcançou sua devida prioridade nas análises das relações internacionais realizadas pelos especialistas brasileiros. Nossas pesquisas demonstraram que, apesar desses recursos serem de grande monta na produção hídrica total do Brasil ${ }^{20}$, ainda são raros estudos nacionais que analisem a questão dos recursos hídricos sob a perspectiva de seu compartilhamento internacional ${ }^{21}$.

Os complexos fatores - de ordem física, política, econômica e social - que interagem e se materializam no território, tornam o gerenciamento de uma bacia hidrográfica transfronteiriça uma tarefa extremamente desafiadora. Problemas relacionados à crescente escassez, à degradação da qualidade dos recursos, ao rápido crescimento populacional, às ações estatais unilaterais e aos diferentes níveis de desenvolvimento sócio-econômico são potenciais motivos de preocupação.

A utilização compartilhada das ATS traz consigo distintos tipos de concorrências, um relacionado aos diferentes usos possíveis (abastecimento

\footnotetext{
${ }^{20}$ Cerca de $82 \%$ da produção hídrica brasileira flui em bacias hidrográficas transfronteiriças, estas representam aproximadamente $60 \%$ da superfície do país. Além disso, a dependência de águas captadas fora território nacional é de $34 \%$ da produção hídrica total (REBOUÇAS, 1999 e UNESCO, 2003).

${ }^{21}$ Entre os escassos trabalhos que apresentam tal abordagem destacamos o de Ribeiro (2004).
} 
público, irrigação, geração de energia, navegação e pesca) e outro envolvendo os diversos usuários (regiões administrativas ou Estados nacionais).

As dificuldades iniciam-se a medida em que os distintos usos competem entre si. Como, por exemplo, quando a construção de uma barragem, com o objetivo principal de geração de eletricidade, compromete o fluxo de cardumes, alterando a atividade pesqueira; ou quando o bombeamento de água para a irrigação diminui ou inviabiliza sua utilização para o abastecimento público como água potável.

Porém, tais dificuldades se agravam em função da dinâmica própria de uma bacia hidrográfica. Considerando-se que o fluxo de sua rede é determinado por gravidade, os impactos gerados à montante repercutirão necessariamente na qualidade e/ou quantidade das águas à jusante. Menos freqüentemente, determinados usos também produzem impactos em trechos à montante. Na TABELA 3.5 sintetizamos os impactos ambientais mais comuns em um sistema hidrográfico, destacando os trechos da rede que são afetados.

É pertinente lembrarmos que muitos dos impactos ambientais apontados vêm acompanhados de impactos sociais, ou sócio-ambientais, como por exemplo: alterações em atividades econômicas e usos tradicionais da terra, perdas de heranças históricas e culturais, efeitos sociais de migrações, problemas de saúde pública, entre outros.

O fato dos divisores de águas - que delimitam as bacias hidrográficas muitas vezes não corresponderem aos limites fronteiriços dos Estados nacionais potencializa a complexidade da questão, tornando-a transnacional. $O$ maior agravante é que, diferentemente das bacias hidrográficas exclusivamente nacionais, as ATS encontram-se submetidas à soberania territorial de dois ou mais países, possuidores de distintos interesses, muitas vezes conflitantes. 
Tabela 3.5 - Principais Impactos Ambientais em Sistemas Hidrográficos

\begin{tabular}{|c|c|c|c|}
\hline Atividade & Impacto Potencial & $\mathrm{M}$ & $\mathrm{J}$ \\
\hline \multirow[t]{2}{*}{ Uso público } & $\begin{array}{l}\text { Diminuição do volume, devido a bombeamentos intensivos } \\
\text { para abastecimento público }\end{array}$ & & $\mathrm{X}$ \\
\hline & $\begin{array}{l}\text { Contaminação/poluição, devido a descargas de esgotos } \\
\text { domésticos e resíduos sólidos }\end{array}$ & & $\mathrm{X}$ \\
\hline \multirow[t]{2}{*}{ Uso industrial } & $\begin{array}{l}\text { Diminuição do volume, devido a bombeamentos intensivos } \\
\text { para suprimento de demandas industrias }\end{array}$ & & $\mathrm{X}$ \\
\hline & $\begin{array}{l}\text { Poluição/contaminação, devido a descargas de e fluxos e } \\
\text { resíduos sólidos }\end{array}$ & & $\mathrm{X}$ \\
\hline \multirow[t]{2}{*}{ Uso agrícola } & $\begin{array}{l}\text { Diminuição do volume, devido a bombeamentos intensivos } \\
\text { para irrigação }\end{array}$ & & $\mathrm{x}$ \\
\hline & Poluição/contaminação, devido a utilização de agrotóxicos & & $\mathrm{X}$ \\
\hline \multirow{3}{*}{$\begin{array}{l}\text { Uso } \\
\text { navegacional }\end{array}$} & Poluição difusa, devido ao tráfego de embarcações & & $\mathrm{X}$ \\
\hline & $\begin{array}{l}\text { Contaminação/poluição, devido a acidentes envolvendo de } \\
\text { vazamento de cargas }\end{array}$ & & $\mathrm{x}$ \\
\hline & $\begin{array}{l}\text { Alteração na velocidade e volume, devido a obras hidráulicas } \\
\text { necessárias para funcionamento de uma hidrovia }\end{array}$ & & $\mathrm{x}$ \\
\hline \multirow[t]{5}{*}{$\begin{array}{l}\text { Uso } \\
\text { energético }\end{array}$} & $\begin{array}{l}\text { Alteração do regime de vazão, devido a construção de } \\
\text { barragens }\end{array}$ & & $\mathrm{X}$ \\
\hline & $\begin{array}{l}\text { Influência na migração dos peixes, devido a construção de } \\
\text { barragens }\end{array}$ & $\mathrm{X}$ & $\mathrm{x}$ \\
\hline & Alterações na fauna, devido alteração na migração de peixes & $\mathrm{X}$ & $\mathrm{X}$ \\
\hline & $\begin{array}{l}\text { Perda de água, devido ao aumento da evaporação nas } \\
\text { represas }\end{array}$ & $\mathrm{X}$ & $\mathrm{x}$ \\
\hline & Inundação de águas agricultáveis & $\mathrm{X}$ & \\
\hline & $\mathrm{M}=$ à montante & & \\
\hline
\end{tabular}


Como podemos concluir a partir da TABELA 3.5, os Estados ribeirinhos situados rio abaixo são os mais vulneráveis, pois são os maiores prejudicados nesses compartilhamentos. Geralmente, partem deles as principais queixas, pois estão sujeitos aos reflexos dos tipos de uso e ocupação do território à montante e dependem de decisões externas à sua soberania. Assim, a posição dos Estados dentro da BHT passa a ser um fator crucial.

Além de ratificar essa última constatação, Le Prestre (2000) ressalta as implicações da posição geográfica nas atitudes estatais frente ao compartilhamento das águas transfronteiriças:

Num contexto de partilha dos recursos de água doce, os Estados a montante possuem uma vantagem certa sobre os Estados à jusante. Seu interesse a cooperar é, por conseguinte, limitado, exceto quando um dos seguintes fatores está presente se: (1) o Estado à jusante possui uma potência militar muito maior(...); (2) o Estado à montante depende do Estado à jusante em matéria de transporte fluvial; (3) os benefícios adicionais de cooperação são claros - o jogo é de soma positiva; (4) a cooperação se inscreve num conjunto de relações múltiplas e integradas (LE PRESTRE, 2000:443).

Com isso, evidencia-se a importância de um elemento clássico da geografia política: o conceito de posição geográfica, aliás, pouco valorizado nos dias atuais. Para o pioneiro Friedrich Ratzel, a posição (lage) consistia "nas relações recíprocas entre o espaço do Estado e o meio circundante" (MELLO, 1999:8).

O geógrafo alemão defendia que atributos "como a extensão, a posição e a configuração dos territórios fornecem os elementos para avaliar a vida dos povos aos quais estes pertencem" (RATZEL, 1914; in: MORAES, 1990:102). Acrescentamos que além da vida dos povos - que vivem no interior de limites estatais - tais atributos também são importantes para analisar as relações entre os Estados. Como podemos concluir, a posição geográfica apresenta-se como um dos principais fatores territoriais que definem eventuais vantagens ou desvantagens nos casos de compartilhamento das ATS. 
Autores contemporâneos também reforçam nossa conviç̧ão quanto à relevância da posição geográfica na interpretação das relações internacionais hodiernas, desde que sejam evitados determinismos simplistas. Raffestin defende que atributos, tais como: dimensão, forma e posição, sejam analisados como códigos sintáticos do território e reconhece que as estratégias dos diferentes Estados ao longo da história foram marcadas por um ou outro desses elementos sintáticos (RAFFESTIN, 1993:23).

Segundo o geógrafo esses códigos sintáticos, acompanhados de um saberver "geométrico", permitem "denotar, se utilizados com prudência, a teoria e a prática das diferentes políticas territoriais, em ligação com a concepção estratégica própria de cada Estado" (RAFFESTIN, 1993:24-25). Da mesma forma, defendemos que a avaliação de tais códigos sintáticos, em especial a posição, mostra-se fundamental nas análises sobre o compartilhamento das ATS.

Também podemos concluir que, o caráter transnacional envolvido na questão torna o compartilhamento dessas águas superficiais uma materialização da problemática apresentada na seção anterior. Isso porque a soberania territorial de cada Estado integrante de uma BHT, passa a ser influenciada por fatores externos. Suas decisões, relativas à utilização desses recursos sempre avaliarão os impactos causados aos seus vizinhos, assim como, não poderão ignorar aos impactos oriundos daqueles situados à montante.

O jurista Jacques Sironneau (1996) ao identificar cinco doutrinas de utilização de águas transfronteiriças, que coexistem atualmente, reflete os diferentes entendimentos relativos ao conceito da soberania:

(1) Doutrina da soberania territorial absoluta: um Estado pode utilizar as águas dentro de seu território nacional da maneira que ele avalie como a melhor, segundo seus interesses nacionais, e sem levar em conta os eventuais efeitos causados fora de suas fronteiras.

(2) Doutrina da integridade territorial absoluta: em oposição da primeira, esta doutrina favorece o Estado à jusante, a medida que lhe garante o direito e os benefícios de um débito natural e ininterrupto de fluxo de água do Estado à montante. 
(3) Doutrina da soberania territorial limitada e integrada: todo Estado tem o direito de utilizar as água dentro de seu território sob a condição de não trazer prejuízo aos interesses de outros Estados. Esta doutrina se inscreve dentro de um quadro de direito de obrigação recíproca na escala da bacia hidrográfica transfronteiriça.

(4) Doutrina da comunidade de interesses: defende que dentro de uma bacia hidrográfica transfronteiriça, nenhum Estado possa dispor das águas sem consultar os outros Estados e estabelecer uma cooperação entre eles (gestão integrada).

(5) Doutrina do uso racional e eqüitativo: todo Estado tem direito de usar as águas da bacia transfronteiriça a qual pertence e atribuir uma parte razoável e eqüitativa aos outros Estados. Essa doutrina marca a resultante das doutrinas precedentes, em particular a 3, 4 e 5 , que podem aparecer combinadas (SIRONNEAU, 1996:66).

Concluímos que as duas primeiras definições baseiam-se na concepção clássica de soberania, ou seja, no princípio da soberania absoluta. Enquanto as demais advogam a soberania compartilhada.

Kenneth Frederick (1996) ao analisar os impasses inerentes a questão das ATS, identifica duas das doutrinas apontadas por Sironneau (1996): (1) a da soberania territorial ilimitada, que conferiria a um dos Estados os direitos exclusivos sobre o uso das águas dentro de seu território; e (2) a teoria da integridade territorial ilimitada, na qual um Estado não pode alterar nem a quantidade nem a qualidade da água que está disponível para outro. Segundo um relatório do Banco Interamericano de Desenvolvimento: "Es obvio que, en la práctica, los países aguas arriba tenderían a favorecer la primera mientras que los países situados aguas abajo favorecerían la segunda" (BID, 1998:22).

A partir dessas constatações, podemos inferir que tanto a defesa da concepção de soberania territorial absoluta - ou ilimitada - quanto a da integridade territorial ilimitada são, na verdade, argumentos empregados para salvaguardar os interesses nacionais. E estes são definidos pela posição geográfica dos países dentro da $\mathrm{BHT}$, visto as vantagens inerentes aos Estados situados à montante. 
Entendemos que em disputas internacionais nas quais um dos Estados opta por uma decisão unilateral, temos a tentativa de defesa incondicional dos interesses nacionais, geralmente apoiada na concepção de soberania absoluta. Já quando os Estados optam por um acordo bilateral ou multilateral, estão operando com a lógica da soberania compartilhada, que encontra respaldo nas três últimas doutrinas identificadas por Sironneau (1996). Também nesses casos, a defesa dos interesses nacionais orientará as decisões de cada país, porém negociada frente aos interesses dos outros.

Como já argumentamos na seção anterior, defendemos que os Estados ao adotarem posturas cooperativas não estão abrindo mão de sua soberania, desde que as negociações e acordos sejam feitos em condições de equidade entre as Partes, sem pressões de qualquer natureza - quer sejam política, econômica ou militar.

Considerando os dois encaminhamentos estatais possíveis - unilateral ou multilateral - a concepção de soberania perante o compartilhamento das ATS deve ser avaliada caso a caso. Esse é um dos nossos objetivos ao analisarmos os eventos interestatais envolvendo as águas superficiais da Bacia do rio Danúbio, tarefa que levaremos a cabo no próximo capítulo.

Antes, porém, acreditamos que se mostra pertinente identificarmos os fatores que determinam, ou ao menos influenciam, os desdobramentos de tais interações relacionadas à água.

\section{2 - Águas transfronteiriças superficiais: conflito ou cooperação?}

Ao considerarmos a importância política, econômica e social dos recursos hídricos; sua crescente escassez e o funcionamento daqueles sistemas hidrográficos que ignoram as distintas jurisdições, identificamos intensas disputas interestatais em torno do compartilhamento das águas transfronteiriças superficiais. Em uma primeira análise, podemos distinguir duas vias de desdobramento para tais disputas: (1) por 
intermédio de negociações e ações cooperativas ou (2) por meio da defesa unilateral dos interesses nacionais, gerando um cenário de conflito.

Para o geógrafo Peter Gleick ${ }^{22}$ (1994):

No todas las disputas sobre recursos hidráulicos acaban em conflicto violento; la mayoria, desde luego, terminan em negociaciones, discusiones o resoluciones pacíficas. Pero en ciertas regiones del mundo, como o Oriente Medio y o sur del Ásia, (...) la probabilidad de estallidos de violencia debidos, al menos em parte, a disputas provocadas por el agua es cada vez mayor (GLEICK, 1994:87).

O cientista político Le Prestre (2000) expressa opinião semelhante ao afirmar que: "apesar da retórica de alguns altos dirigentes, os conflitos sobre a água raramente degeneram em conflitos violentos" (LE PRESTRE, 2000:461).

As afirmações de Gleick e Le Prestre apresentadas acima, podem ser confirmadas por meio de análises empíricas realizadas dentro do projeto Basins at Risk (BAR). Os resultados apresentados pelo projeto BAR são frutos de uma pesquisa contínua e em evolução, que utiliza os recursos do Transboundary Freshwater Dispute Database (TFDD) ${ }^{23}$ e tem como principais objetivos:

(1) Collect and analyze biophysical, socioeconomic, and geopolitical data in a Geographic Information System, and use these factors to determine historically based indicators for future tensions within international basins;

(2) Identify basins that are at risk of conflict for the coming decade using indicators determined in the initial investigation; and

(3) Identify and assess the potential for mitigating factors and new technologies that may allow for a future different than that predicted

\footnotetext{
${ }^{22}$ Gleick é pesquisador-chefe do Pacific Institute for Estudies in Development, Environment and Security, na Califórnia

${ }^{23}$ Este banco de dados é, resultado de pesquisas realizadas, ao longo de uma década, por um grupo do Oregon State University Department of Geosciences, apoiado pela Northwest Allience for Computational Science and Engineering. O projeto é coordenado pelo geógrafo Aaron T. Wolf.

As informações do TFDD também subsidiaram o World Water Development Report (UNESCO,2003) e o Atlas of International Freshwater Agreements (UNEP, 2002), amplamente citados em nosso trabalho.
} 
by historically based indicators (WOLF; STAHL e MACOMBER, 2003:2).

A partir do projeto BAR/TFDD, foram computadas e analisadas interações relacionadas ao compartilhamento de água entre dois ou mais países e, ao longo de 50 anos (1950-2000), foi contabilizado um total de 1.831 eventos $^{24}$. Os resultados apontam para uma ampla prevalência da via cooperativa, já que 1.228 interações tomaram tal encaminhamento, enquanto ocorreram 507 casos conflitivos (WOLF; STAHL e MACOMBER, 2003).

Para avaliar o grau dessas interações foi desenvolvido um sistema de contagem (BAR scale) que determinou valores de intensidade para cada evento, que variam de -7 (mais alto potencial conflitivo, atribuído a eventuais casos de guerra formal) até +7 (mais alto potencial de cooperação, atribuído a eventuais casos de fusão voluntária de países) ${ }^{25}$. No Anexo I deste trabalho, apresentamos a Water Event Intensity Scale na íntegra.

A distribuição dos eventos é detalhada pelo GRÁFICO 3.1. Além do predomínio da cooperação, uma avaliação sob os dados aponta que a maior parcela dos eventos $(42,8 \%)$ foi enquadrada entre as categorias de apoio verbal moderado (+1) e hostilidade verbal moderada (-1). Demonstrando a prevalência de interações brandas, ou seja, aquelas em que a manifestação verbal por parte dos Estados substitui atitudes mais afirmativas, tanto no sentido da cooperação, quanto do conflito.

Observamos também a ocorrência de apenas 37 casos de conflitos agudos, no qual a violência chegou a ocorrer (-5 e -6), os estudos ainda mostram que esses casos não são recentes ou difundidos (WOLF; STAHL e MACOMBER, 2003:2).

\footnotetext{
${ }^{24}$ Nesse estudo "water event" foi definido como casos de conflito ou cooperação dentro de uma BHT, referentes a água como um recurso consumível ou escasso (ex. qualidade, quantidade) ou como quantidade a ser gerenciada (ex. inundações, níveis de água para navegação). Foram excluídos eventos nos quais a água não foi um elemento essencial à disputa, tais como aqueles referentes a direitos à pesca, acesso a portos, transporte ou rios fronteiriços. Também foram excluídos aqueles eventos nos quais a água não foi um pivô (driver), tais como aqueles em que ela foi um pedágio, alvo ou vítima de um conflito armado.

${ }^{25}$ Para maiores detalhes sobre a metodologia da escala $B A R$, ver: Yoffe, Wolf e Giordano (2003) e Yoffe e Larson (2002).
} 
Os resultados do estudo BAR/TFDD comprovam que, apesar de serem relativamente escassos, os desdobramentos violentos são uma realidade, o que demonstra que cenários futuros com essa forma de desfecho não podem ser descartados, sobretudo quando consideramos a crescente escassez apresentada no capitulo 1. Nesse sentido os autores alertam:

In the future, there will be international conflicts over water, and it may be that such conflicts will increase given increasing populations or other stresses upon the resource. The question is how and at what level of intensity such conflicts will be dealt with by the parties concerned (YOFFE; WOLF e GIORDANO, 2003:1124).

\section{GRÁFICO 3.1}

\section{Eventos em bacias transfronteiriças}

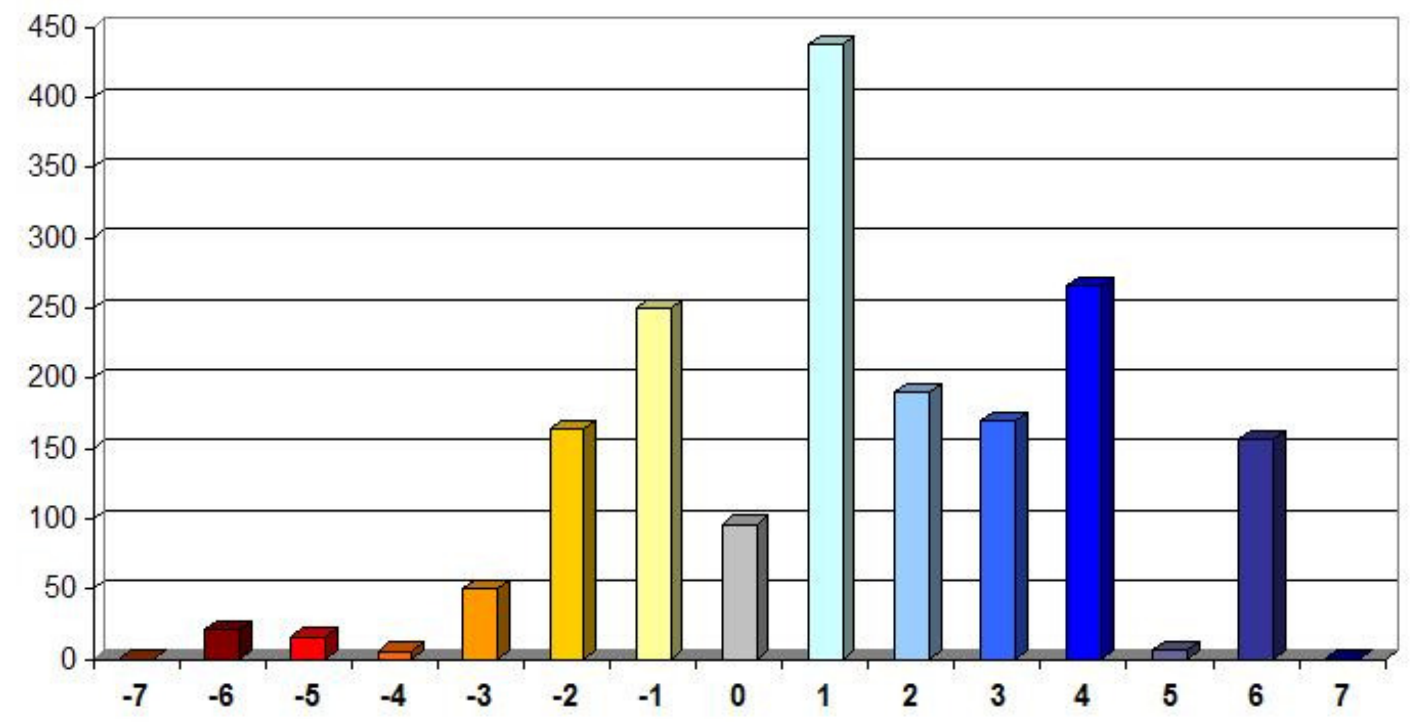

-7 Guerra formal

-6 Ações militares de grande escala

-5 Ações militares de pequena escala

$\square-4$ Ações políticas/militares hostis

$\square-3$ Ações diplomáticas/econômicas hostis

$\square-2$ Hostilidade verbal forte/oficial

$\square-1$ Hostilidade verbal leve/ não oficial

0 Ações neutras/ não significativas

\section{0}

21

16

6

50

164

250

96

\section{Apoio verbal leve}

2 Apoio verbal oficial

3 Acordo/apoio cultural científico

4 Acordo não militar, econômico, tecnológico e industrial

5 Apoio militar, econômico e estratégico

6 Tratado internacional de águas

7 Unificação em uma nação 
Gráfico 3.2

\section{Distribuição de eventos cooperativos}

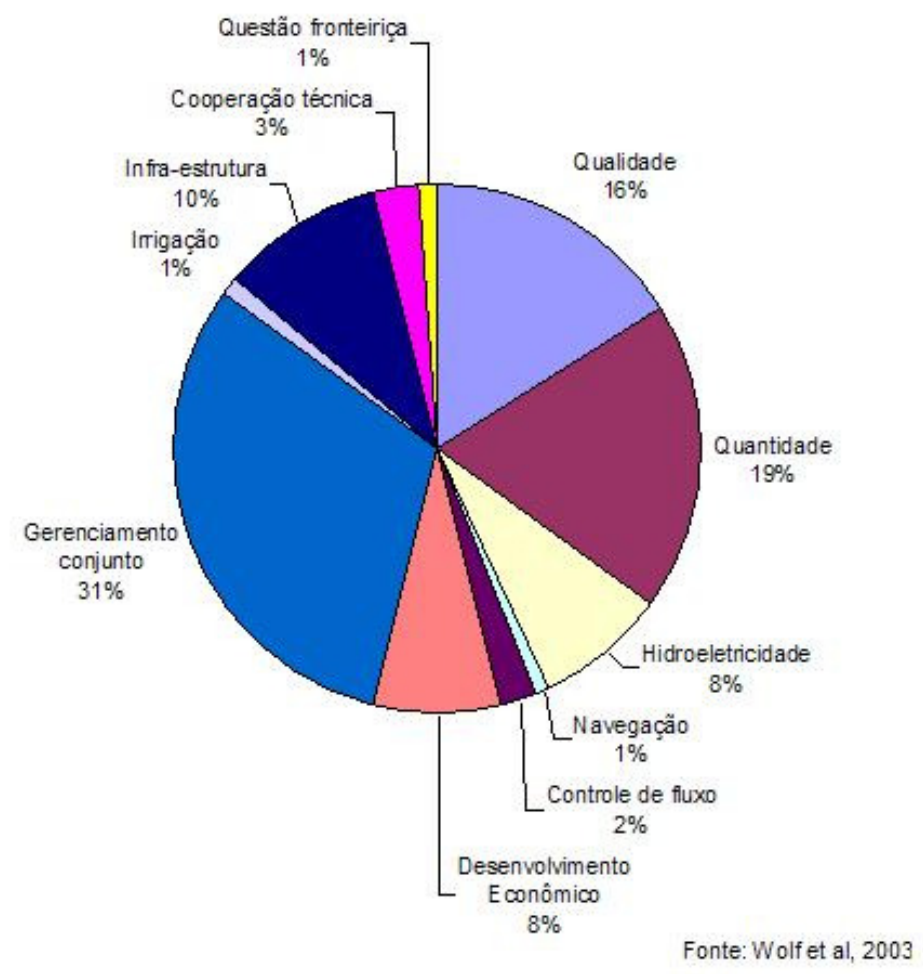

Gráfico 3.3

\section{Distribuição de eventos conflitivos}

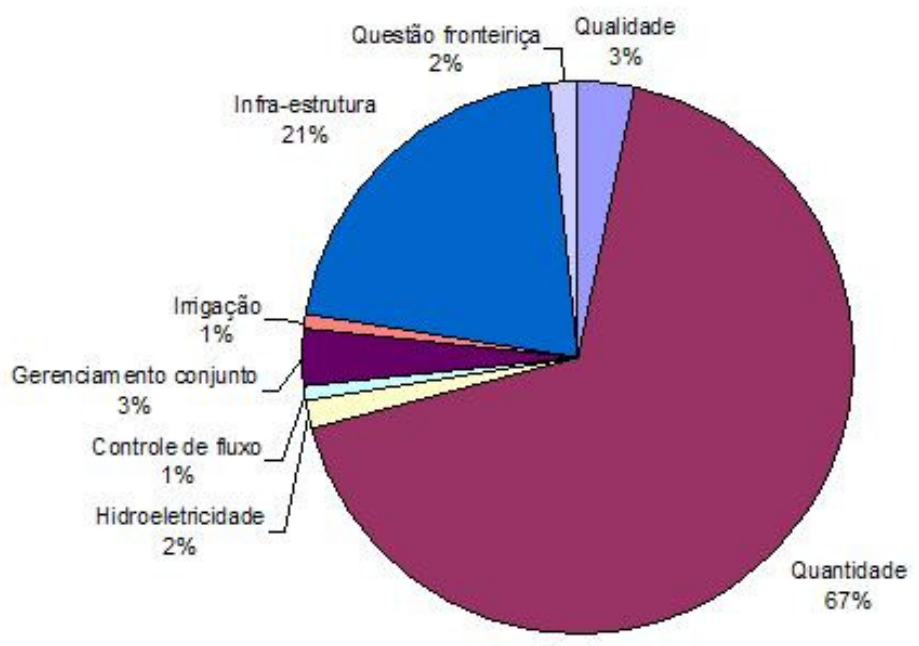

Fonte: Wolf et al, 2003 
Além disso, a proporção de interações conflitivas - cerca de $28 \%$ demonstra que atualmente não é pequena a capacidade de disputas por águas transfronteiriças degradar as relações entre países. WOLF, STAHL e MACOMBER (2003) citam como exemplos os casos: Índia e Paquistão, Israel e Jordânia, EUA e Canadá.

O GRÁFICO 3.2 demonstra que os países cooperam sobre um amplo leque de assuntos relacionados às águas superficiais: gerenciamento conjunto, qualidade, quantidade, infra-estrutura, entre outros. Já a partir do GRÁFICO 3.3, constatamos que os eventos conflitivos concentram-se (86\%) em duas questões: quantidade e infra-estrutura. Além disso, dos casos mais extremos (-6 ou -5) quase $100 \%$ incidem sobre essas duas questões (WOLF, STAHL e MACOMBER, 2003:3).

Em nosso entendimento, o valor estratégico da água fornece um caráter conflitivo inerente ao seu compartilhamento internacional, afinal, além de indispensável à vida e ao desenvolvimento sócio-econômico, esse recurso é fonte de poder. Aliás, a história da humanidade está repleta de exemplos de competição e conflitos pela água. Mesmo muito antes do surgimento do Estado moderno, as disputas pelo controle da água já eram uma prioridade geopolítica dos mais diversos grupos sociais.

Aldo Rebouças (1999) nos lembra que desde os primórdios das civilizações antigas, a apropriação das fontes de água representava um importante instrumento de poder e exemplifica com situações em que a via do unilateralismo foi determinante. O geólogo cita casos como o da Mesopotâmia, onde o controle dos rios, para dominação dos povos que habitavam setores hidrográficos à jusante foi praticado desde $4 \mathrm{mil} \mathrm{aC}$; como o do Nilo, cujo controle das inundações foi a base do poder da civilização Egípcia, desde 3,4 mil aC; e como os dos vales do Indo e do Amarelo, em que a utilização da água como forma de poder era feita por intermédio de obras para o controle de enchentes, irrigação e abastecimento, desde 3 mil aC; entre outros (REBOUÇAS, 1999:17-19).

Gleick (1994) enfatiza que a água e seus sistemas de abastecimento também tem sido meio e causa de guerras no mundo contemporâneo. Nesse sentido enumera três tipos de situações possíveis. 
A primeira delas é quando se encara o controle da água como objetivo militar. Considerando-se que o controle de recursos constitui-se como um fator na definição do poder de uma nação, a água proporciona uma fonte de poder econômico e/ou político. Assim, justificaria-se entrar em guerra por recursos hídricos ou tais recursos serem abordados como objetivos de conquista militar. Exemplifica esta situação apontando a água como um dos focos dos conflitos na bacia do Rio Jordão, e destacando que uma das conseqüências da Guerra de 1967 foi a ocupação das cabeceiras daquele rio por Israel. Além de apontar o fato de que mais de 40 \% da água subterrânea de que depende Israel, provém de territórios ocupados (GLEICK, 1994:88-89).

Outra situação destacada é quando sistemas de abastecimento são vistos como alvos militares. Exemplifica lembrando que durante a Segunda Guerra e a Guerra das Coréias as represas hidroelétricas eram bombardeadas com rotina, assim como os sistemas de irrigação do Vietnã, nos anos 60. Além dos ataques aéreos israelenses a sistemas hidráulicos sírios que tentavam desviar as águas do Rio Jordão, em meados dos anos 60 . Também são citados os ataques à represas e plantas de dessalinização e a sistemas de transporte de água por ambos os lados envolvidos na Guerra do Golfo (GLEICK, 1994: 89).

Por fim, também deixa claro que a utilização dos recursos hidráulicos pode ser encarada como instrumentos de guerra. Considerando-se que atualmente muitos instrumentos não militares são utilizados para alcançar fins bélicos, observa-se que em alguns casos o recurso manipulado é a água. A simples percepção de que esse recurso possa ser utilizado como elemento político pela nação rival já pode levar a violência. O plano da Coréia do Norte, por exemplo, de construir uma represa em um afluente do rio Han, inquietou a Coréia do Sul pelo temor de que a represa pudesse ser utilizada como instrumento para interromper o abastecimento ou até mesmo poderia ser empregada como arma militar de intenção ofensiva. Os analistas da Coréia do Sul previram que a destruição proposital da represa poderia aumentar o nível do rio em 50 metros, suficientes para destruir a capital Seul. No Oriente médio, as transformações hidroelétricas e agrícolas no rio Eufrates tem sido consideradas como fontes de instabilidade regionais. Em 1974, o Iraque ameaçou bombardear a 
represa de Thawra, na Síria, alegando que o volume de água que corria para seu território havia diminuído por conta da obra. A construção da represa de Ataturk, em 1990, em território turco, trouxe à Síria e Iraque queixas e temores semelhantes àqueles dos Sul Coreanos em relação aos seus vizinhos do Norte (GLEICK, 1994:90-91).

Em suas conclusões, reafirma que a água na atualidade é fonte de conflitos e que esse cenário certamente se agravará no futuro. Apesar de reconhecer que as disputas relacionadas à água tendem a gerar mais enfrentamentos e negociações políticas do que conflitos violentos, ela manifesta preocupação com o crescente potencial conflitivo defendendo a urgência de trabalhos que objetivem reduzir a probabilidade e as conseqüências dos conflitos derivados da água (GLEICK, 1994:106).

Michael Klare (2002) ao analisar conflitos de matriz ambiental enfocou as disputas referentes ao compartilhamento das ATS na bacia do rio Jordão e na bacia do rio Nilo. Em suas conclusões o autor afirma que a escassez crescente desse recurso não precisa, necessariamente, conduzir a guerra, porém alerta para esse perigo em regiões que já apresentam interações conflituosas em outros temas. Em suas palavras:

In areas where states enjoy good relations with one another and have a history of resolving differences through peaceful negotiations, disputes over shared of water can be addressed without recourse to violence. However, some the most acute disputes over such supplies have arisen in regions where intergovernamental relations are fractious and where competition over water and other vital resources has led to fighting in the past. In these areas, future shortages are likely to inflame local tensions and increase the risk of war- especially if one party to dispute believes that another is appropriating more than rightful share of water (KLARE, 2002:140).

Por conta do potencial conflitivo envolvido na questão, o compartilhamento das águas transfronteiriças tem permeado os estudos daqueles que vêm se dedicando à temática da segurança ambiental internacional. Como já 
demonstramos, não são poucos os especialistas que reconhecem as disputas por tais recursos como geradoras ou intensificadoras de instabilidades regionais.

Mas afinal, quais seriam os fatores que determinam o desfecho das interações estatais relacionadas ao compartilhamento das águas transfronteiriças? Quais seriam os indicadores de conflitos futuros?

Os estudos do geógrafo Peter Gleick $(1993,1994)$ possuem grande respeitabilidade na literatura especializada e representam esforços no sentido de avaliar a vulnerabilidade de um Estado quanto à ocorrência de conflitos relacionados a disputas por recursos hídricos.

Gleick aponta quatro indicadores de vulnerabilidade:

(1) relação entre demanda anual e disponibilidade anual de água de cada país;

(2) disponibilidade de água por pessoa;

(3) grau de dependência de águas superficiais importadas; e

(4) grau de dependência da hidroeletricidade como fonte de energia elétrica (GLEICK, 1994,97).

O geógrafo ressalta que tais índices não devem ser tomados como definitivos, já que em muitas regiões do globo os dados sobre recursos hidráulicos são limitados ou pouco confiáveis. Porém enfatiza que estas medidas podem ser extremamente úteis para identificar regiões com potencial conflitivo e para subsidiar ações cooperativas regionais ou a intervenção de organizações internacionais (GLEICK, 1994: 98).

Le Prestre também reconhece que a água, como qualquer outro recurso, pode se tornar um objeto de conflito e aponta variáveis idênticas àquelas indicadas por Gleick (1994), a saber:

(1) grau de dependência dos países;

(2) escassez;

(3) número de atores que reivindicam acesso;

(4) potencial militar desses atores;

(5) existência de produtos substitutivos, inexistentes no momento; e 
(6) caráter simbólico do recurso, em termos políticos ou culturais (LE PRESTRE, 2000:442).

Enfatizamos que os indicadores ressaltados acima são reflexos dos mais variados fatores naturais, sociais e econômicos que se sintetizam no território. Assim evidencia-se o papel crucial do controle do território para a sobrevivência dos Estados e grupos sociais. A questão do compartilhamento das ATS comprova, contrariando afirmações surgidas no final do século passado, que o território e suas respectivas fronteiras possuem e sempre possuirão um caráter basilar nas relações interestatais, pelo menos enquanto não surgir um substituto para a água.

Os indicadores apontados por Gleick (1994) e Le Prestre (2000) utilizam os limites nacionais como unidade de análise, sendo que o geógrafo concentra sua análise em componentes físicos envolvidos no sistema: água e energia.

Os pesquisadores do projeto BAR/TFDD também se dedicaram à avaliação de potenciais de conflito ou de cooperação envolvendo as ATS, porém seus estudos utilizaram os limites das BHT como unidade de análise e contaram com testes empíricos-estatísticos.

Os resultados divulgados por Yoffe, Wolf e Giordano (2003) demonstraram que nenhum único indicador - incluindo: clima, estresse hídrico, tipo de governo ou dependência de água para agricultura ou energia, entre outros - explicou os casos de conflitos ou cooperação sobre água, portanto nenhum desses parâmetros mostrou-se pertinente em si mesmo. Até mesmo aqueles indicadores que mostram alguma correlação significante com conflito de água - como alta densidade demográfica, baixa renda per capita e relações internacionais hostis - explicaram só uma pequena porcentagem da variabilidade de dados.

Considerando que a maioria dos parâmetros geralmente identificados como indicadores de conflito estão, na verdade, fracamente ligados à disputa, os pesquisadores do projeto BAR/TFDD sugerem que a "capacidade institucional" dentro de uma bacia ou um relacionamento internacional positivo é tão, ou mais, importante que os aspectos físicos de um sistema hidrográfico. Nesses estudos, a 
"capacidade institucional" foi definida pela existência de grupos de gerenciamento ou de tratados internacionais sobre o tema.

Ainda segundo essa análise, os indicadores pertinentes estão ligados a mudanças rápidas ou extremas nos cenários institucionais ou físicos. Assim, quando a taxa de mudança dentro de uma bacia excede a "capacidade institucional" para absorver tal mudança é provável encontrar-se tensões. As mudanças institucionais mais rápidas estariam associadas a bacias recém internacionalizadas - aquelas repentinamente foram divididas entre dois ou mais países. Enquanto as mudanças físicas mais rápidas estariam relacionadas com a construção de uma represa ou projeto de desvio (YOFFE; WOLF e GIORDANO, 2003:1124).

O WWDR (UNESCO, 2003), baseado nos estudos BAR/TFDD, aponta três indicadores de potencial conflitivo:

(1) bacias internacionalizadas que incluem estruturas de gestão de países que conquistaram sua independência recentemente;

(2) bacias onde se elaboraram projetos unilaterais e onde os regimes políticos não têm feito nenhum esforço de cooperação; e

(3) bacias onde os governos são hostis a respeito de questões não relacionadas com a água (UNESCO, 2003:320) - tradução do autor.

A partir das distintas concepções metodológicas de avaliação de risco em $\mathrm{BHT}$, podemos concluir que o potencial conflitivo inerente à questão é definido por fatores geográficos e políticos, o que demonstra a pertinência e a relevância da utilização do arcabouço teórico próprio da geografia política na interpretação dessas situações.

Por nosso turno, defendemos que as variáveis ligadas aos eventos interestatais dessa natureza podem ser sintetizadas e distinguidas da seguinte maneira:

(1) variáveis territoriais: referentes àqueles indicadores ligados aos estoques e demandas hídricas, que são determinados por fatores naturais, econômicos e sociais, que se materializam fisicamente no território. 
(2) variáveis políticas: indicadas pelo contexto geopolítico e pela "capacidade institucional" dentro da bacia hidrográfica transfronteiriça. Em outras palavras, relações internacionais positivas ou negativas relativas a outros temas e existência de grupos de gerenciamento comum e/ou tratados sobre águas internacionais também devem ser consideradas na avaliação.

Esclarecemos que a distinção apresentada acima foi estabelecida para efeitos analíticos, já que ambos tipos de variáveis são intrinsecamente ligados. Afinal, os recursos hídricos estão inseridos em territórios nacionais e administrados por Estados soberanos.

Defendemos que a identificação de tais variáveis pode proporcionar 0 diagnóstico de bacias hidrográficas transfronteiriças sob risco na atualidade e ajudar a traçar cenários futuros, contribuindo, assim, para criação de mecanismos capazes de atuarem na mitigação e prevenção de conflitos.

Para o cumprimento dessa última tarefa, são necessários estudos mais detalhados. Entendemos que esses estudos devem ser realizados utilizando a bacia hidrográfica transfronteiriça como principal unidade de análise, mas não devem preterir as variáveis dimensionadas na escala nacional, já que é em função de seus estoques e demandas hídricas que os países tomam suas decisões. Somente os estudos de caso podem responder quanto ao peso específico de cada grupo de fatores - territoriais e políticos - já que em cada situação haverá um desdobramento particular. Baseado nisso, analisaremos, no capítulo seguinte, as interações interestatais na Bacia do Rio Danúbio.

Consideramos pertinente também ressaltar que não é só em casos conflitivos que as variáveis geopolíticas são determinantes. Na próxima seção, ao analisarmos as negociações e ações cooperativas referentes ao compartilhamento das águas transfronteiriças, incluindo as tentativas de regulamentação, enfatizaremos que os atributos políticos-territoriais também são decisivos nas posturas dos Estados envolvidos.

\section{3 - O compartilhamento das águas transfronteiriças superficiais: um subsistema da ordem ambiental internacional}


Acompanhamos a mais de três décadas a criação de um aparato institucional que busca a regulamentação da gestão dos recursos hídricos em escala internacional. Trata-se de um conjunto de Conferências e Fóruns internacionais, que produziram Declarações e Planos de Ação no intuito de fomentar o uso racional desse recurso. $\mathrm{Na}$ TABELA 3.6 sintetizamos as principais etapas deste processo.

O geógrafo Wagner Ribeiro (2004) apresenta uma análise detalhada desses eventos, identificando-os como rodadas de um subsistema da OAI específico aos recursos hídricos e que está em desenvolvimento. Em sua avaliação:

O aparato institucional em formação para a regulamentação dos recursos hídricos em escala internacional propõe o compartilhamento destes, chocando-se com a soberania dos países e a prevalência da legislação nacional na exploração da água (RIBEIRO, 2004:129).

Entendemos que é possível reconhecer um subsistema interno àquele identificado por Ribeiro (2004) quando analisamos as diversas iniciativas e negociações para a regulamentação das ATS.

As Conferências e Fóruns da TABELA 3.6 representam, em parte, essas iniciativas. Porém, ao avaliarmos os documentos finais dessas rodadas ${ }^{26}$ da OAI encontramos escassas e vagas decisões relacionadas ao compartilhamento das ATS e/ou gestão de BHT.

De uma forma geral, os documentos contêm trechos que preconizam a cooperação internacional, porém sempre de forma bastante breve e superficial. Como, por exemplo, na Declaração de Marrakesh (1997) que se limita a recomendar "o estabelecimento de um mecanismo efetivo para administração das águas compartilhadas".

De forma semelhante, o artigo $11^{\circ}$ da Declaração Ministerial de Kyoto (2003): cognizing that cooperation between riparian states on transboundary and/or boundary watercourses contributes to sustainable water management and mutual benefits, we encourage all those states to promote such cooperation (Declaração Ministerial de Kyoto, 2003).

\footnotetext{
${ }^{26}$ Disponíveis em:< www.unesco.org/water/waap/milestones $>$. Acesso em 20 set 2005.
} 
Tabela 3.6 - Principais reuniões internacionais sobre água

\begin{tabular}{|c|c|c|c|}
\hline Datas & Eventos & Resultados & Principais questões \\
\hline 1977 & $\begin{array}{l}\text { Conferência das } \\
\text { Nações Unidas sobre } \\
\text { Água, Mar Del Plata }\end{array}$ & $\begin{array}{l}\text { Plano de Ação de } \\
\text { Mar Del Plata, } \\
\text { Década Internacional } \\
\text { da Água (1981-1990) }\end{array}$ & $\begin{array}{l}\text { Avaliação de recursos hídricos; } \\
\text { Eficiência e uso da água }\end{array}$ \\
\hline 1992 & $\begin{array}{l}\text { Conferência } \\
\text { Internacional sobre } \\
\text { Água e Ambiente, } \\
\text { Dublin }\end{array}$ & $\begin{array}{l}\text { Declaração de } \\
\text { Dublin sobre Água } \\
\text { e Desenvolvimento } \\
\text { Sustentável }\end{array}$ & $\begin{array}{l}\text { Valor econômico da água; } \\
\text { mulher; pobreza, resolução de } \\
\text { conflitos; desastres naturais; } \\
\text { conscientização }\end{array}$ \\
\hline 1994 & $\begin{array}{l}\text { Conferência } \\
\text { Ministerial sobre Água } \\
\text { Potável e } \\
\text { Saneamento, } \\
\text { Noordwijk }\end{array}$ & Programa de Ação & $\begin{array}{l}\text { Suprimento de água potável e } \\
\text { saneamento }\end{array}$ \\
\hline 1997 & $\begin{array}{l}1^{\circ} . \text { Fórum Mundial da } \\
\text { Água, Marrakesh }\end{array}$ & $\begin{array}{l}\text { Declaração de } \\
\text { Marrakesh }\end{array}$ & $\begin{array}{l}\text { Água e saneamento; } \\
\text { gerenciamento de águas } \\
\text { compartilhadas; preservação de } \\
\text { ecossistemas; equidade de } \\
\text { gênero; uso eficiente da água }\end{array}$ \\
\hline 1998 & $\begin{array}{l}\text { Conferência sobre } \\
\text { Água e } \\
\text { Desenvolvimento } \\
\text { Sustentável, Paris }\end{array}$ & $\begin{array}{l}\text { Declaração de Paris } \\
\text { sobre Água e } \\
\text { Desenvolvimento } \\
\text { Sustentável }\end{array}$ & $\begin{array}{l}\text { Conhecimento sobre recursos } \\
\text { hídricos; recursos humanos e } \\
\text { institucionais para gestão da } \\
\text { água; estratégias de gestão } \\
\text { sustentável e financiamentos }\end{array}$ \\
\hline 2000 & $\begin{array}{l}2^{\circ} . \text { Fórum Mundial da } \\
\text { Água, Haia }\end{array}$ & $\begin{array}{l}\text { Visão Mundial da } \\
\text { Água; } \\
\text { Declaração } \\
\text { Ministerial: } \\
\text { Segurança da Água } \\
\text { no Século XXI }\end{array}$ & $\begin{array}{l}\text { Segurança alimentar; } \\
\text { necessidades básicas; proteção } \\
\text { de ambientes naturais; } \\
\text { compartilhamento de recursos } \\
\text { hídricos; gerenciamento de } \\
\text { riscos; valoração da água; } \\
\text { governança }\end{array}$ \\
\hline 2001 & $\begin{array}{l}\text { Conferência } \\
\text { Internacional sobre } \\
\text { Água Doce, Bonn }\end{array}$ & $\begin{array}{l}\text { Declaração } \\
\text { Ministerial; } \\
\text { Recomendações } \\
\text { para Ação }\end{array}$ & $\begin{array}{l}\text { Governança; } \\
\text { recursos financeiros; } \\
\text { conhecimento compartilhado }\end{array}$ \\
\hline 2003 & $\begin{array}{l}\text { 3ó. Fórum Mundial da } \\
\text { Água, Kyoto }\end{array}$ & $\begin{array}{l}\text { Declaração } \\
\text { Ministerial }\end{array}$ & $\begin{array}{l}\text { Gerenciamento integrado; } \\
\text { gênero; pobreza; financiamento; } \\
\text { cooperação; uso eficiente; } \\
\text { prevenção de poluição; } \\
\text { mitigação de desastres }\end{array}$ \\
\hline
\end{tabular}


Dentre os documentos apresentados na TABELA 3.6 é a Declaração de Dublin sobre Água e Desenvolvimento Sustentável (1992) que aborda a temática da solução de conflitos referentes a águas transfronteiriças de forma mais direta. Segundo ela:

La entidad geográfica más apropiada para la planificación y gestión de los recursos hídricos es la cuenca fluvial, incluyendo aguas de superficie como subterráneas. En teoría, una planificación y explotación integrada y eficaz de cuencas fluviales o lacustres transfronterizas suponen necesidades institucionales similares a las de una cuenca que se encuentra dentro de un solo país. La función esencial de las organizaciones responsables de las cuencas internacionales consiste en conciliar y armonizar los intereses de los países ribereños, medir sistemáticamente la cantidad de agua y su calidad, elaborar programas de acción concertados, intercambiar información y dar cumplimiento a los acuerdos. En los decenios venideros, la gestión de las cuencas internacionales cobrará gran importancia. Por consiguiente, se deberá atribuir alta prioridad a la elaboración y ejecución de planes integrados de gestión, refrendados por todos los gobiernos afectados y respaldados por acuerdos internacionales (Declaração de Dublin, 1992).

Entendemos que a escassez de proposições referentes ao compartilhamento das ATS nessas Declarações e Planos de Ação reflete as polêmicas em torno da questão. Mesmo se tratando de documentos não vinculantes, acreditamos que os representantes dos Estados evitam aprovar assertivas mais contundentes em favor da gestão integrada em BHT e da cooperação internacional para evitar o comprometimento do princípio da soberania nacional em futuras negociações e Tratados sobre o tema.

Até mesmo o documento firmado em Dublin, que aborda a gestão das BHT de forma direta, não apresenta maiores comprometimentos para os seus signatários. Tal Declaração, por exemplo, não explicita direitos e deveres dos Estados, tampouco 
aponta qual concepção de soberania - absoluta ou compartilhada - deve ser adotada pelos Estados co-ribeirinhos.

Assim como em outros subsistemas da OAl, a ONU e suas agências especializadas vêm desempenhando um papel basilar na evolução do processo de institucionalização da gestão internacional dos recursos hídricos, estudado por Ribeiro (2004). Afinal, as reuniões internacionais destacadas na TABELA 3.6 foram realizadas sob seus auspícios diretos ou indiretos: a Conferência de Mar Del Plata foi convocada pela Secretaria Geral; a Conferência de Dublin foi coordenada pela Organização Mundial de Meteorologia (OMM); a Conferência de Noordwijk foi convocada pelo governo da Holanda, com apoio da ONU; sob a coordenação da UNESCO, realizou-se Conferência de Paris; enquanto a Conferência de Bonn foi feita sob os auspícios do governo alemão em cooperação com a ONU.

Os três Fóruns Mundiais da Água foram coordenados pelo Conselho Mundial da Água (CMA). Esse Conselho foi criado a partir de proposta apresentada na Conferência de Dublin, que foi reforçada na CNUMAD e na Conferência de Noordwijk. Em março de 2004, o CMA contava com a participação de 323 organizações de 53 países, agregando agências representantes de Estados, empresas transnacionais do setor de abastecimento e saneamento, além de universidades e centros de pesquisa. Sua atuação limita-se a de formador de opinião, defendendo abertamente o comércio mundial de recursos hídricos (RIBEIRO, 2004:144).

Mas as iniciativas relacionadas na TABELA 3.6 não representam os únicos elementos do subsistema específico das ATS, que está em construção. Entendemos que os acordos internacionais referentes à regulamentação da gestão águas transfronteiriças, bem como suas respectivas rodadas de negociações, também compõem esse processo. Premissa que torna necessária a compreensão dos mecanismos jurídicos relacionados à temática.

O jurista Guido Soares (2002) esclarece que foi no século XX, que as utilizações dos cursos d'água internacionais mostraram suas reais dificuldades e contradições. Afinal as funções de delimitação de fronteira e de navegação, principais preocupações dos Estados até então, foram contrapostas a outras 
necessidades, como a construção de grandes barragens para geração de eletricidade e as crescentes demandas de água potável (SOARES, 2002:421). Acrescentamos que, também foi nesse século que a modernização da agricultura transformou essa atividade na maior consumidora de água, respondendo atualmente por cerca de $70 \%$ do consumo mundial.

Como reflexo dessa nova realidade, observa-se uma significativa evolução na abordagem do Direito Internacional frente às questões referentes aos recursos hídricos, esse fato pode ser constatado a partir da utilização de conceitos cada vez mais abrangentes. Soares (2001) aponta a introdução do conceito de bacia hidrográfica em documentos internacionais ${ }^{27}$ como conseqüência do reconhecimento de que um rio internacional integra um complexo hidrográfico e humano mais amplo do que uma simples via de acesso aquático. Outro avanço citado foi à revolucionária inserção do conceito águas transfronteiriças ${ }^{28}$, associado ao de impactos transfronteiriços. Suas palavras sobre essas mudanças são as seguintes:

Sem dúvida, a emergência do conceito "água", como valor supremo que deve ser protegido, é devido ao Direito Internacional do Meio Ambiente, e que tende a sobrepor-se a outros fins na utilização de um rio ou lago internacionais, sobretudo quando se torna um bem escasso, em virtude da perda das suas qualidades dirigidas à satisfação de necessidades imediatas e elementares dos componentes da biosfera, entre os quais se encontra o homem (SOARES, 2001:240).

Ressaltamos que, do ponto de vista geopolítico, a intensificação dos usos distintos da navegação das águas transfronteiriças superficiais trouxe significativas modificações na defesa dos interesses dos Estados ribeirinhos. Isto porque, aqueles (situados à montante) que possuíam desvantagens em relação à navegabilidade, passam a ter a vantagem de poder usar o rio para outros fins de acordo com sua vontade, como, por exemplo, utilizando-o como vetor para o mar de seus resíduos

\footnotetext{
${ }^{27}$ Utilizado pela primeira vez na Convenção e Estatutos Relativos ao Desenvolvimento da Bacia do Tchad, em 1964.

${ }^{28}$ Utilizado pela primeira vez na Convenção sobre a Proteção e Uso dos Cursos d'Água Transfronteiriços e Lagos Internacionais, em 1992.
} 
tóxicos ou intensificando o bombeamento para o abastecimento público, irrigação etc. Conforme demonstramos, nessas situações o ônus sócio-ambiental recai sobre os Estados situados à jusante.

Assim, as novas demandas e as crescentes preocupações ambientais, tornaram a questão do compartilhamento das ATS ainda mais complexa e delicada.

Devido a sua escala geográfica - regional ou subcontinental - 0 compartilhamento das ATS é regulamentado por regimes jurídicos bastante específicos, pois os Tratados sobre a questão são regionais e fechados e por isso submetidos a regras casuísticas de acordo com as particularidades geográficas e políticas dos Estados envolvidos.

A FAO documentou mais de 3600 Tratados referentes às águas transfronteiriças, criados no período entre 805 d.C. e 1984. No que pese o fato da vasta maioria desses acordos tratar de usos navegacionais, verifica-se um crescente aumento de documentos focalizando a água como um recurso consumível e limitado, à parte da navegação, pesca e questões fronteiriças. Incluídos nessa última categoria existe mais de 400 tratados, firmados desde 1820, que se encontram detalhados no Atlas of International Freshwater Agreements (UNEP, 2002:6).

O jurista Stephen Mc Caffrey (1993) esclarece que, na maioria dos casos, a regulamentação conjunta das águas transfronteiriças é feita por intermédio de Tratados bilaterais. Entendemos que essa característica desse subsistema da OAI reafirma a importância das particularidades geográficas e políticas envolvidas na questão, como vimos a posição geográfica e outras variáveis territoriais são fundamentais na definição dos interesses nacionais e só podem ser avaliadas caso a caso, utilizando-se a bacia hidrográfica transfronteiriça como unidade de análise. Ressaltamos que não são raras as situações em que Estados localizam-se a montante de determinados rios e à jusante de outros, por isso a adesão a um acordo global poderia trazer ganhos em um caso, mas perdas em outro.

Contudo Mc Caffrey (1993) reconhece um constante crescimento dos acordos multilaterais, a respeito deles o jurista constata: 
Embora seja difícil generalizar, pode-se dizer com certa confiança que muitos tratados que distribuem quantidade ou qualidade de água entre os Estados envolvidos, ou estabelecem mecanismos de manutenção, refletem o princípio de utilização eqüitativa. (...) O que é eqüitativo deve ser determinado em cada caso individual, de acordo com todos os fatos e circunstâncias relevantes. Mas a natureza caso-a-caso da determinação não afeta a generalização do princípio. (...) Outra regra básica refletida pela prática dos tratados, embora talvez não tão fortemente, é que um Estado não pode, através de suas ações que afetam cursos de água internacionais, prejudicar significativamente outros estados. Especialistas também reconhecem a natureza fundamental dessa regra, embora alguns mantenham que é subordinada ao princípio da utilização eqüitativa (Mc CAFFREY: 1993:98) - tradução do autor.

A única iniciativa de se criar um Tratado de âmbito global relativo ao compartilhamento das ATS refere-se às negociações em torno da Convenção sobre Cursos d'Água Internacionais (CCAI) ${ }^{29}$.

Conforme o Artigo 38 do Estatuto da Corte Internacional de Justiça (CIJ), trata-se de uma das escassas fontes de lei, relacionadas aos recursos hídricos, que governam as relações entre Estados soberanos. Apesar de ainda não ter entrado em vigor, ela representa a opinião dos principais especialistas e possui um caráter de referência, já que suas linhas gerais são cada vez mais utilizadas em fóruns internacionais (UNESCO, 2003:302-303).

Após quase três décadas de trabalhos da Comissão de Direito Internacional (CDI) das Nações Unidas ${ }^{30}$, o projeto da CCAI foi apresentado à sua Assembléia Geral, que aprovou sua adoção em 21 de maio de $1997^{31}$. A referida Convenção codifica muitos dos princípios considerados essenciais pela comunidade

\footnotetext{
${ }^{29}$ A denominação oficial em inglês dessa Convenção é: Convention on the Law of the Non-navigational Uses of Internacional Watercourses.

${ }^{30}$ ILC (International Law Comision) formada por 34 especialistas, de vários países, que são eleitos pela Assembléia Geral.

${ }^{31}$ Por meio da Resolução 51/229.
} 
internacional para o gerenciamento compartilhado dos recursos hídricos, incluindo o preceito da utilização eqüitativa e razoável.

Em 37 artigos, o documento também fornece regras para guiar Estados em negociações de acordos futuros sobre usos distintos da navegação de cursos d'água internacionais, regulamentando medidas de proteção, conservação e gerenciamento dos mesmos. Considerada como uma Convenção-quadro (framework Convention), ela endereça questões visando: controle de inundações, qualidade da água, erosão, sedimentação, intrusão de água salgada e introdução de espécies estranhas. Ela não legisla sobre os usos de navegação, exceto quando outros usos afetem a navegação ou sejam por ela afetados. $\left({ }^{32}\right)$

Sobre a natureza da CCAI, Soares afirma:

trata-se de um documento que pretendeu levar ao nível multilateral e universal, na forma de ato cogente, as práticas que já se acham vigentes na imensa maioria dos acordos fluviais e de pesca nas relações bilaterais entre os Estados, e naqueles multilaterais anteriormente citados. Sendo assim, a tarefa da CDI, no que respeita aos rios transfronteiriços e lagos internacionais, foi mais um exercício de suas atribuições de "codificação do Direito Internacional" (...) (SOARES, 2001:258).

A adoção foi decida por uma votação, que apresentou o seguinte resultado: 103 votos favoráveis, 3 votos contrários (Burundi, China e Turquia) e 27 abstenções. O número de Estados que se absteve ou votou contra demonstra a falta de consenso sobre várias provisões-chave.

No centro das polêmicas encontramos a questão da soberania nacional. A CCAl, como não poderia deixar de ser, é baseada na concepção de soberania compartilhada ou na doutrina da soberania territorial limitada e integrada, para utilizarmos a conceituação de Sironneau (1996). Entre os muitos artigos do documento que refletem essa concepção, o artigo $5^{\circ}$ merece destaque.

Artigo 5: Equitable and reasonable utilization and participation

\footnotetext{
${ }^{32}$ Para uma análise jurídica dos principais artigos dessa Convenção ver SOARES, 2001.
} 
1. Watercourse States shall in their respective territories utilize an international watercourse in an equitable and reasonable manner. In particular, an international watercourse shall be used and developed by watercourse States with a view to attaining optimal and sustainable utilization thereof and benefits therefrom, taking into account the interests of the watercourse States concerned, consistent with adequate protection of the watercourse.

2. Watercourse States shall participate in the use, development and protection of an international watercourse in an equitable and reasonable manner. Such participation includes both the right to utilize the watercourse and the duty to cooperate in the protection and development thereof, as provided in the present Convention. (CCAl, 1997. Disponível em <www.internationalwaterlaw.org>. Acesso em 25 ago 2005).

Com já vimos, a doutrina do uso razoável e eqüitativo é a resultante de outras doutrinas apoiadas na noção de soberania compartilhada. Evidentemente, ao aceitarem tais obrigações, os Estados abrem mão de eventuais reivindicações baseadas nos princípios da soberania territorial absoluta e da integridade territorial absoluta.

Estados que não votaram a favor da adoção, criticam diretamente o fato do texto não salvaguardar o princípio da soberania territorial, esse foi o caso da China, Índia, Turquia e Ruanda, sendo as seguintes palavras do representante desse último país: "a Convenção careceu de qualquer referência ao sacrossanto princípio da soberania dos Estados" 33 (o grifo é nosso).

O artigo $7^{\circ}$ também representa fonte de muitas divergências.

Artigo 7- Obligaton not to cause significant harm

1. Watercourse States shall, in utilizing an international watercourse in their territories, take all appropriate measures to prevent the causing of significant harm to other watercourse States.

\footnotetext{
${ }^{33}$ Conforme:Press Release, United Nations General Assembly Plenary, 21 may 1997 (GA/9248). Disponível em $<$ www.internacionalwaterlaw.org $>$. Acesso em 27 ago 2003.
} 
2. Where significant harm nevertheless is caused to another watercourse State, the States whose use causes such harm shall, in the absence of agreement to such use, take all appropriate measures, having due regard for the provisions of articles 5 and 6, in consultation with the affected State, to eliminate or mitigate such harm and, where appropriate, to discuss the question of compensation.

(CCAI, 1997. Disponível em <www.internationalwaterlaw.org>. Acesso em 25 ago 2005).

Considerando a dinâmica das bacias hidrográficas, analisada no início desse capítulo, e a obrigação de não causar dano significativo, explicitada no artigo acima, concluímos que a Convenção garante os direitos dos Estados situados à jusante.

Além disso, a análise dos dois artigos transcritos acima evidencia que em uma situação de conflito entre eles a obrigação de não prejudicar outros Estados (artigo $7^{\circ}$ ) prevalece sobre a utilização eqüitativa (artigo $5^{\circ}$ ). Este entendimento é explicitado no comentário da CDI referente ao $7^{\circ}$ artigo da CCAI:

O direito de um Estado de utilizar um curso de água internacional de forma eqüitativa e razoável tem seus limites no dever de não causar grandes danos a outros Estados que utilizam o mesmo curso d'água. Em outras palavras, a utilização de águas internacionais não é eqüitativa se prejudica outros Estados" (Relatório da CDI nos Trabalhos de sua 43ํㅗㄴ Sessão, apud Mc CAFFREY, 1993:99) tradução do autor.

Por esses motivos 0 artigo $7^{0}$ foi alvo de "duras" críticas feitas por países situados à montante de disputas em BHT, já que ele proporcionaria vantagens a países localizados rio abaixo.

Assim, a suposta falta de equilíbrio nas provisões entre direitos e deveres dos Estados ribeirinhos situados à montante e à jusante também esteve no centro das divergências. Essa foi uma das objeções da China e da Etiópia, sendo que o 
representante deste país explicitou que "a Convenção foi inclinada aos interesses dos Estados ribeirinhos localizados à jusante das fontes impactantes". ${ }^{34}$

Lembramos que China e Etiópia localizam-se em partes altas de BHT, como a do Salween e do Nilo respectivamente, e possuem um histórico de litígios com seus vizinhos co-ribeirinhos (Cf. GRASA, 1994:33). Por isso, suas declarações e decisões de votar contra (China) e abster-se (Etiópia) são claras demonstrações da defesa de seus interesses nacionais, definidos pelas circunstâncias geográficas e políticas de cada um deles.

Entendemos que a análise das declarações frente à adoção da CCAl já é suficiente para identificarmos a presença de posturas realistas nessa negociação. Constatamos que a defesa dos interesses nacionais e da soberania foi reiteradamente utilizada, de forma explícita ou velada, nas justificativas dos Estados contrários às provisões da Convenção. Até mesmo, países pouco expressivos no sistema internacional - tanto em termos de poder militar quanto em poder econômico - como é o caso de Ruanda, adotaram incondicionalmente tais posicionamentos.

Todavia a maior prova de que o realismo político prevalece nesse subsistema da OAI está no fato de que a CCAI ainda não agregou o número de Partes necessário para entrar em vigor, e não há expectativas de que isso aconteça em curto ou médio prazo.

O texto da Convenção prevê, no artigo 36, sua entrada em vigor 90 dias após o depósito do $35^{\circ}$ instrumento de ratificação, aceitação, aprovação ou adesão. 0 documento esteve aberto para assinaturas durante o período de 21/05/1997 até 20/05/2000, mas continua aguardando o incremento de Estados Partes, por tempo indefinido. Atualmente, em outubro de 2005, ela possui 16 Estados Signatários e apenas 12 Estados Partes.

Chama-nos a atenção, a discrepância entre o número de Estados que votaram favoravelmente à adoção - um total de 151 - e aqueles que efetivamente se comprometeram com os direitos e obrigações da CCAl - apenas 12. Essa grande diferença demonstra que o real interesse da maioria dos países só pode ser avaliado

\footnotetext{
${ }^{34}$ Conforme:Press Release, United Nations General Assembly Plenary, 21 may 1997 (GA/9248). Disponível em $<$ www.internacionalwaterlaw.org $>$, acesso em out de 2005.
} 
a partir de iniciativas concretas, nas quais obrigações e deveres são juridicamente assumidos pelos Estados. Entendemos que a postura de "apoiar" o acordo enquanto ele não possui efeito vinculante e protelar indefinidamente 0 efetivo comprometimento com o mesmo é mais um artifício utilizado pelos Estados para salvaguardar sua soberania e os interesses nacionais na arena internacional.

A Hungria encontra-se entre os poucos Estados que assumiram compromissos com a $\mathrm{CCAl}^{35}$, enquanto a Eslováquia foi um dos países que votou a favor da adoção, mas não assinou o Tratado até os dias atuais. Por ocasião da Assembléia Geral realizada no dia 21/05/1997 a Eslováquia deixou transparente sua discordância na declaração de seu voto, realizada pelo seu representante:

\begin{abstract}
JAN VARSO (Slovakia) "said that during the Working Group's session, Slovakia has abstained in a vote on the draft convention because its articles 5, 6 and 7 should have better reflected the objective of ensuring the reasonable and equitable use of international watercourses by downstream and upstream States. Nevertheless, his country supported the Organization's efforts to codify international law and to implement Charter principles. Since the current text contained a framework designed to promote equitable and reasonable cooperation among downstream and upstream States, and with the hope that its application would contribute to the progressive development of international law, Slovakia would vote in favour of it. ${ }^{36}$
\end{abstract}

Como veremos no próximo capítulo, Hungria e Eslováquia são os protagonistas dos principais conflitos pelo compartilhamento das águas da bacia do rio Danúbio. Como também demonstraremos as variáveis territoriais e políticas, em especial a posição geográfica, dão coerência à postura desses países frente a CCAI.

Segundo Ribeiro (2004) a inexistência de uma Convenção específica para a gestão dos recursos hídricos internacional, de escopo mundial, possibilita uma série

\footnotetext{
${ }^{35}$ Assinatura em 20/07/1999 e aprovação em 26/01/2000.

${ }^{36}$ Conforme:Press Release, United Nations General Assembly Plenary, 21 may 1997 (GA/9248). Disponível em $<$ www.internacionalwaterlaw.org $>$ Acesso em 25 set 2005.
} 
de conseqüências. O geógrafo manifesta sua inquietação em relação a duas delas: o comércio internacional da água e o conflito gerado por ela (RIBEIRO, 2004:128).

Além CCAl, o artigo 38 do Estatuto da ClJ também aponta a Convenção sobre Proteção e Utilização de Cursos d'Água Transfronteiriços e Lagos Internacionais, como uma das raras fontes relativas ao compartilhamento de águas transfronteiriças. Esta Convenção foi firmada em março de 1992, na cidade de Helsinque, e passou a vigorar em outubro de 1996.

Trata-se de uma moderna Convenção que, pela primeira vez, traçou normas gerais do Direito Fluvial Internacional, pois não regulamenta um rio específico ou uma determinada bacia hidrográfica. Essa Convenção foi negociada sob a égide da Comissão Econômica das Nações Unidas para a Europa (UNECE) e possuía originalmente um caráter regional e fechado, já que somente os Estados membros daquela Comissão poderiam ser admitidos como integrantes. Atualmente, outubro de 2005, o Tratado possui 35 Partes.

Em recente decisão ${ }^{37}$, as Partes da Convenção de Helsinque abriram a possibilidade de também consentir a adesão de Estados fora da região da UNECE. Isso significa que será possível outras regiões do globo utilizarem esse arcabouço legal e se beneficiar dessa experiência de cooperação.

$O$ objetivo desse acordo é fortalecer as medidas nacionais de gerenciamento sustentável das águas transfronteiriças superficiais e subterrâneas. A Convenção obriga as Partes a controlar e reduzir a poluição das águas, além de definir providências para: monitoramento, pesquisa, sistema de alarme, assistência mútua, arranjos institucionais, troca e proteção de informações, entre outras.

Segundo o jurista Soares (2001) a Convenção de Helsinque possui:

um texto complexo, verdadeiro código internacional sobre normas jurídicas e técnicas relacionadas a tratamento de águas, (...). Tratase de um autêntico 'umbrella treaty' em que se traçam normas mínimas que deverão os Estados Partes respeitar, nas respectivas legislações internas, bem como normas sobre os princípios de

\footnotetext{
${ }^{37}$ Tomada na $3^{\text {a }}$. Reunião de Partes, realizada em Madrid, em novembro de 2003.
} 
políticas e de regras que deverão os estados Partes adotar em suas relações bilaterais e/ou multilaterais. (SOARES, 2001:248).

De certa forma, a assinatura da referida Convenção representou uma interessante antecipação da Conferência do Rio, pois apresentam dois princípios que seriam formalmente adotados, alguns meses mais tarde, na Declaração do Rio: o princípio da precaução e o princípio do poluidor-pagador. O primeiro aparece no texto referindo-se ao transporte de material perigoso e seu envolvimento com possíveis acidentes. O segundo, à adoção do poluidor como responsável pelas conseqüências ambientais que causou.

Ao compararmos a CCAI com a Convenção de Helsinque, encontramos nesta, assertivas menos contundentes no que diz respeito à soberania e à repartição das águas transfronteiriças. O documento de 1992 não é taxativo, por exemplo, quanto à doutrina de uso eqüitativo e razoável nem quanto à obrigação de não causar danos a outros Estados, pontos de maior discórdia na CCAI. Encontramos referências a esses princípios no artigo $2^{\circ}$.

\section{Artigo 2}

2- As Partes, em particular, devem tomar todas as medidas apropriadas: (...)

(c) para assegurar que se faça um uso razoável e eqüitativo das águas transfronteiriças, tendo particularmente em conta seu caráter transfronteiriço, no caso de atividades que causem ou possam vir a causar um impacto transfronteiriço (...)

3- Estas medidas não devem resultar, direta ou indiretamente, de nenhum transfer de poluição para outros lugares. (Convenção de Helsinque, 1992. Disponível em <www.diramb.gov.pt>. Acesso em 18 mar 2003).

A definição de impacto transfronteiriço foi feita no artigo $1^{\circ}$ :

2 - A expressão 'impactos transfronteiriços' designa todo e qualquer efeito adverso significativo sobre o ambiente que resulte de uma alteração no estado das águas transfronteiriças, causada pela 
atividade humana cuja origem física se situe total ou parcialmente na área sob jurisdição de uma das Partes, sobre uma área sob jurisdição de outra Parte. [o grifo é nosso] (Convenção de Helsinque, 1992. Disponível em <www.diramb.gov.pt> Acesso em 18 set 2003).

Constatamos que esta conceituação de "impactos transfronteiriços" enfatiza a questão da qualidade das águas, em detrimento da questão da quantidade. Conforme transcrição acima, o texto limita-se aos impactos que alterem o "estado" das águas, sem nada mencionar sobre o "volume" das mesmas. Assim, o princípio de uso eqüitativo e razoável e a obrigação de não causar dano a outro Estado ficam reduzidos aos aspectos da qualidade das águas, relacionados, principalmente, a poluição.

Entendemos que esta restrição, aos aspectos qualitativos, das obrigações mencionadas acima foi fundamental para a ampla aceitação do documento e de sua rápida entrada em vigor, já que as maiores polêmicas e disputas relativas a águas transfronteiriças ocorrem em torno de questões quantitativas. Como já demonstramos, os resultados do projeto BAR/TFDD apontam que a grande maioria dos eventos conflitivos (67\%) registrados foram por causa da quantidade, enquanto apenas 3\% ocorreram por conta da qualidade das águas.

Considerando as constatações de Yoffe, Wolf e Giordano (2003), que apontam as relações internacionais positivas como uma importante variável na definição de interações relativas as águas transfronteiriças, ressaltamos que o contexto de crescente integração da então CEE (Comunidade Econômica Européia) certamente contribuiu para o sucesso desse desfecho cooperativo.

Temos, no caso da Convenção de Helsinque, uma demonstração de que a teoria da interdependência, proposta inicialmente por Nye e Keohane (1973) e reafirmada por Columbus (1986), também se mostra útil para a compreensão de algumas rodadas do subsistema referente às ATS.

Assim como em outros episódios da OAl, as tentativas de regulamentação da gestão das águas transfronteiriças por meio de Convenções internacionais permitem detectar o papel fundamental do sistema ONU, visto as funções 
desempenhadas pela CDI e UNECE na condução da CCAl e da Convenção de Helsinque, respectivamente.

Nesta seção, demonstramos a evolução do processo que visa regular 0 gerenciamento compartilhado das ATS, identificando-o como um subsistema específico da OAl. Porém, constatamos que ele não atingiu o mesmo estágio de desenvolvimento de outros subsistemas, como, por exemplo, aqueles referentes às mudanças climáticas e à biodiversidade.

Entre as singularidades do subsistema relativo às ATS, destaca-se a ausência de uma Convenção de âmbito global, contrastando com a existência de inúmeros tratados bilaterais e multilaterais que buscam regulamentar o compartilhamento em escala regional.

Nossas análises evidenciam que tais particularidades são reflexos das circunstâncias geográficas e políticas envolvidas na questão. Por um lado, a prevalência da defesa dos interesses nacionais não permitiu que a CCAl entrasse em vigor. Por outro, os limites e a dinâmica das BHT, assim como os desafios inerentes a esses sistemas hidrográficos, levam os Estados a fecharem acordos na escala regional, na qual os ganhos e/ou perdas são ponderados caso a caso, a partir das variáveis territoriais e políticas de cada $\mathrm{BHT}$.

Essas constatações, reforçadas pelas análises da bibliografia referente a segurança ambiental internacional, leva-nos a concluir que a escala subcontinental delimitada pelas BHT - é a que mais adequada para avaliações mais conclusivas sobre o potencial conflitivo/cooperativo da questão. Afinal os conflitos, polêmicas e iniciativas cooperativas têm se materializado, até os dias de hoje, nessa escala geográfica.

Por isso, completaremos nossa dissertação analisando uma bacia hidrográfica transfronteiriça de alta complexidade: a do rio Danúbio. No próximo capítulo, discutiremos os principais pontos levantados até esse momento utilizando os eventos interestatais relativos ao compartilhamento das águas superficiais daquela bacia como estudo de caso. 


\section{Capítulo 4 - As águas transfronteiriças superficiais da Bacia do Rio Danúbio}

Neste capítulo abordaremos as disputas e iniciativas de compartilhamento relativas às águas transfronteiriças superficiais (ATS) da bacia do rio Danúbio. Assim, teremos a oportunidade de analisar como as variáveis e os processos discutidos nos capítulos anteriores se materializam em um caso concreto.

Iniciaremos com uma caracterização geográfica da bacia enfatizando circunstâncias naturais, sociais e econômicas relacionadas à distribuição dos recursos hídricos. Em seguida, baseado no banco de dados do projeto BAR/TFDD, apresentaremos os eventos interestatais ocorridos na região entre 1948-2000. Nessa etapa, evidenciaremos os principais protagonistas de interações conflitivas: Eslováquia e Hungria, que passarão a ter um papel central em nossa interpretação.

Para subsidiar a interpretação desses eventos, faremos um diagnóstico das variáveis territoriais e das variáveis políticas da Bacia do Rio Danúbio. Para identificar o primeiro grupo de variáveis, utilizaremos os indicadores de vulnerabilidade apontados por Peter Gleick (1994). Já para o segundo grupo, analisaremos os cenários geopolíticos daquela região da Europa e a capacidade institucional dentro da bacia, conforme postulados de Yoffe, Wolf e Giordano (2003).

Com a conclusão desse capítulo, estamos convencidos de que conseguiremos cumprir o objetivo principal de nossa pesquisa: contribuir para a identificação dos fatores geográficos e políticos que circundam a questão das ATS.

\section{1- Caracterização geográfica da bacia}

A bacia do Rio Danúbio situa-se no coração da Europa central, drenando uma área de $790.100 \mathrm{~km}^{2}$, equivalente a quase $10 \%$ da Europa continental. A bacia é compartilhada por 17 Estados, englobando integralmente o território da Hungria; a maior parte dos territórios da Romênia, Áustria, Eslovênia, Croácia e Eslováquia; 
parcelas significativas da Bulgária, Alemanha, República Tcheca, Moldávia, Ucrânia, Bósnia-Herzegovina, República Sérvia e Montenegro; além de pequenos trechos da Suíça, Itália, Albânia e Polônia.

Trata-se da bacia com o maior número de Estados co-ribeirinhos do globo, atributo que the confere relevância nos estudos referentes ao compartilhamento de ATS. A TABELA 4.1 apresenta, em valores absolutos e relativos, a distribuição da área total da bacia, segundo sua divisão político-territorial.

TABELA 4.1

\begin{tabular}{|c|r|r|}
\hline \multicolumn{2}{|c|}{ Bacia do Rio Danúbio } \\
\hline Países & Área da bacia nos países \\
\hline & 228.500 & $\%$ \\
\hline Romênia & 92.800 & 28,93 \\
\hline Hungria & 81.600 & 11,74 \\
\hline Áustria & 81.500 & 10,32 \\
\hline Sérvia e Montenegro & 59.000 & 10,31 \\
\hline Alemanha & 45.600 & 7,47 \\
\hline Eslováquia & 40.900 & 5,77 \\
\hline Bulgária & 38.200 & 5,17 \\
\hline Bósnia-Herzegovina & 35.900 & 4,83 \\
\hline Croácia & 29.600 & 4,54 \\
\hline Ucrânia & 20.500 & 3,75 \\
\hline República Tcheca & 17.200 & 2,59 \\
\hline Eslovênia & 13.900 & 2,18 \\
\hline Moldávia & 2.500 & 1,76 \\
\hline Suíça & 1.200 & 0,32 \\
\hline Itália & 700 & 0,15 \\
\hline Polônia & 200 & 0,09 \\
\hline Albânia & 790.100 & 0,03 \\
\hline Total & \\
\hline & & 100 \\
\hline
\end{tabular}

Fonte: UNEP, 2002:79 
Devido a condicionantes físico-territoriais - tais como posição, dimensão, geomorfologia e clima - a bacia do Rio Danúbio mostra uma grande diversidade de paisagens naturais, incluindo: altas montanhas congeladas, montanhas e colinas florestadas, planaltos de terras altas, planícies e pântanos ao nível do mar.

O rio Danúbio possui uma direção geral leste-oeste e percorre cerca de 2.780 $\mathrm{km}$, sendo considerado o segundo rio mais longo da Europa, logo depois do Volga. Suas nascentes situam-se na Floresta Negra, região alemã próxima aos limites territoriais da Suíça e da França. Após percorrer o sul do território alemão, o rio atravessa o norte da Áustria, o sul da Eslováquia e cruza a Hungria de norte a sul. Seguindo seu curso, o Danúbio determina as seguintes fronteiras: da Croácia com a República da Sérvia e Montenegro; deste último Estado com a Romênia e o deste com a Bulgária. Finalmente, corta o sudeste da Romênia antes de desaguar no Mar Negro, já na fronteira com a Ucrânia. Nesse longo trajeto, o Danúbio banha quatro capitais: Viena, Bratislava, Budapeste e Belgrado.

Além dos países já citados, seus afluentes cruzam regiões da Eslovênia, Bósnia-Herzegovina e Moldávia. Os rios que drenam a bacia em seu alto curso são originários dos Alpes (situados na Alemanha e Áustria); já no médio e baixo curso seus afluentes nascem das principais elevações do relevo da península balcânica, tais como: Alpes Dináricos (situados na República da Sérvia e Montenegro) e Balcãs (situados na Bulgária); além de afluentes provenientes dos Montes Cárpatos (situados na Romênia).

O Rio Danúbio desemboca em um grande delta pantanoso de aspecto tropical que se estende por uma área de 675.000 ha - 80 \% na Romênia e 20 \% na Ucrânia e é considerado o complexo natural mais importante da bacia. Foi designado como local de patrimônio da humanidade e como reserva da biosfera pela UNESCO (ICPDR, 2005).

Por conta de sua grande extensão leste-oeste e ao relevo diverso, a bacia do rio Danúbio apresenta grandes diferenças no clima. No oeste as regiões superiores mostram forte influência do clima temperado atlântico, com precipitação elevada de chuvas; enquanto que as regiões orientais são afetadas pelo clima temperado continental, com precipitações mais baixas e típicos invernos frios. Nas áreas da 
bacia situadas na península Balcânica, as influências do clima mediterrâneo também podem ser detectadas.

A heterogeneidade do relevo, em especial as diferenças na extensão da exposição aos ventos oeste, assim como as diferenças de altitude, também contribuem para a diversificação do padrão geral do clima. Em conseqüência, a precipitação na bacia possui uma grande amplitude, variando de 500 milímetros a mais de 2000 milímetros anuais.

O regime hidrográfico do rio Danúbio, em particular o regime de descarga, é distintamente influenciado pelos padrões regionais de precipitação. Isto está ilustrado no GRÁFICO 4.1, que mostra a contribuição da água de superfície de cada país à descarga cumulativa do rio Danúbio.

Como podemos constatar, a Áustria mostra, de longe, ter a maior contribuição $(22,1 \%)$ seguida por Romênia (17.6 \%). Isto reflete a precipitação elevada nos Alpes e nos Montes Cárpatos. Na parte superior do Danúbio, o rio Inn contribui com o volume principal da água, adicionando mais água ao Danúbio do que ele próprio possui neste ponto de confluência. Na média são os rios: Drava, Tisza e Sava, que juntos contribuem com quase a metade da descarga total que alcança o Mar Negro (ICPDR, 2005).

Esses condicionantes físico-territoriais influenciam diretamente os estoques hídricos renováveis dos países, principalmente daqueles que têm grande parte de seu território dentro da bacia. O GRÁFICO 4.2, ilustrado pelo MAPA 4.1, demonstra os totais de recursos hídricos renováveis disponíveis dentro dos limites nacionais. 


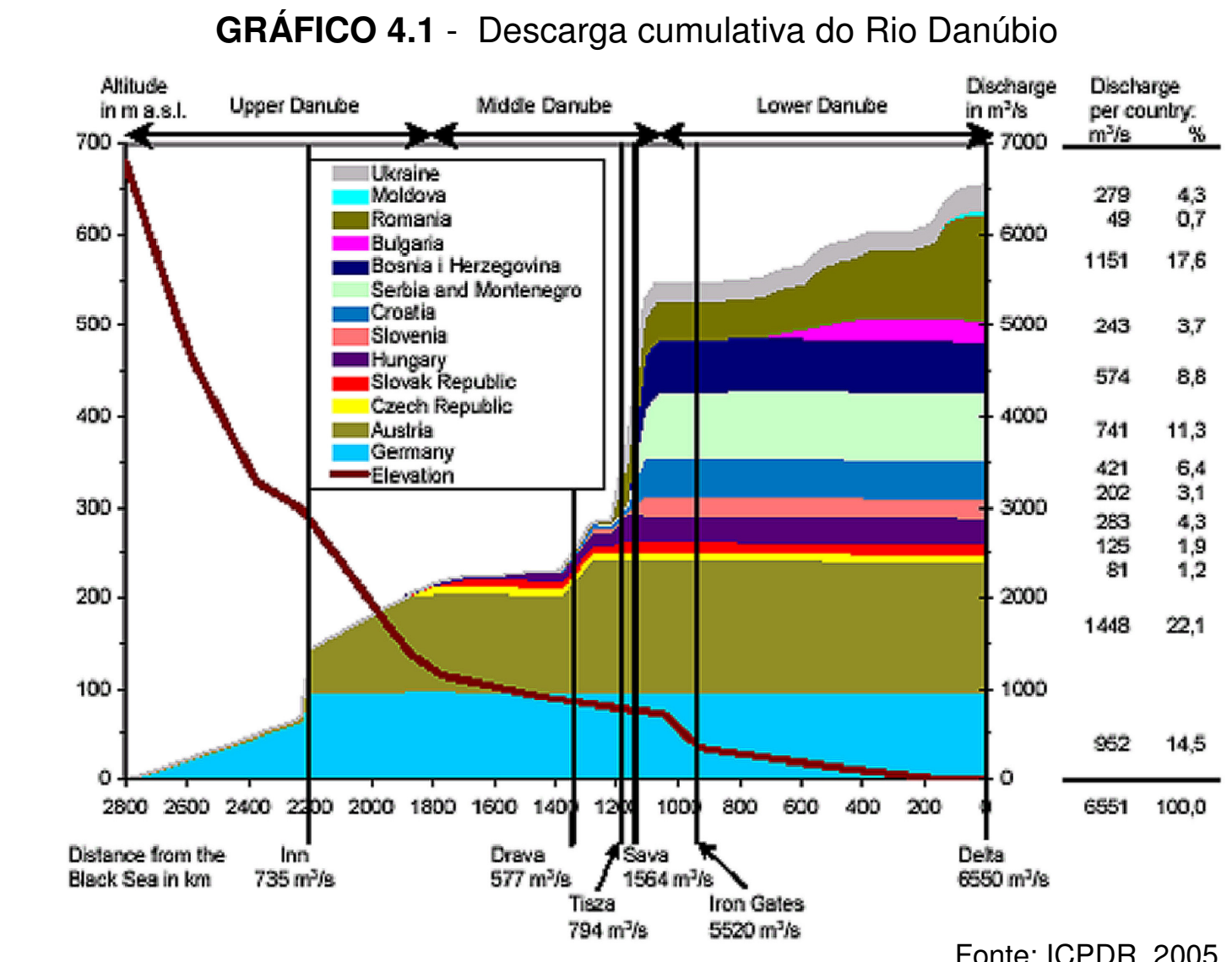

\section{GRÁFICO 4.2}

\section{Bacia do Danúbio \\ TOTAL DE RECURSOS HÍDRICOS RENOVÁVEIS - 2003}

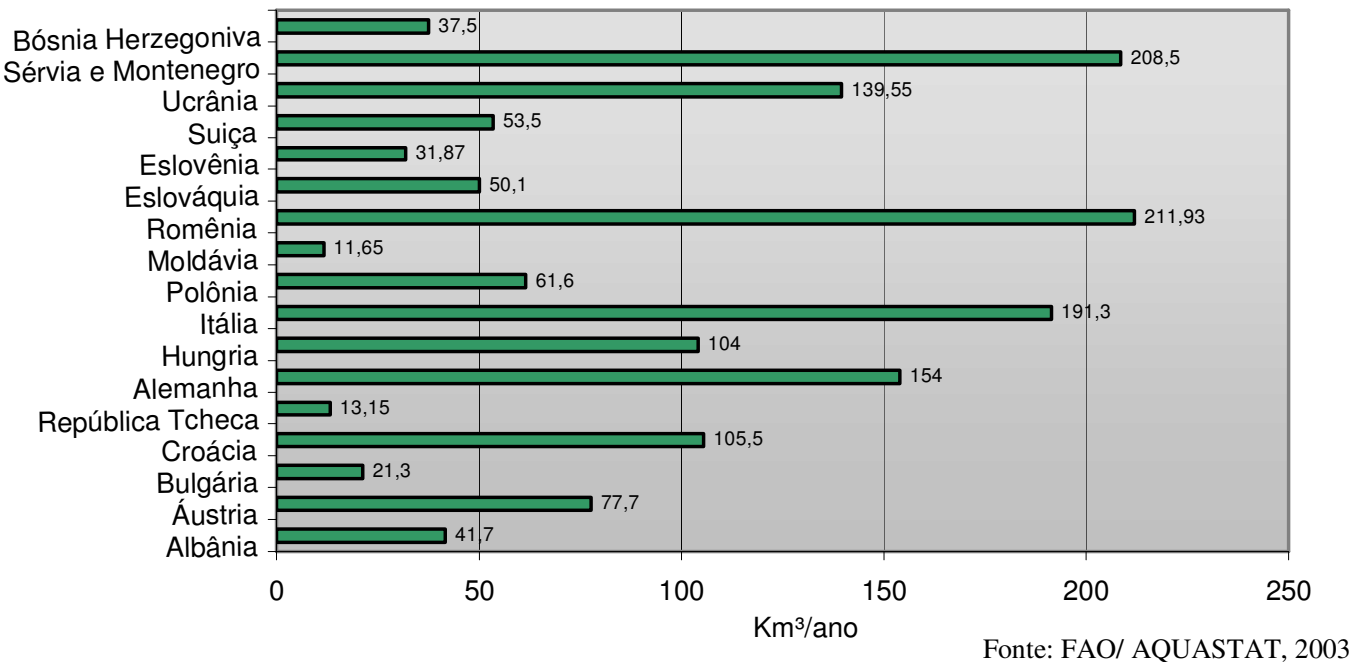




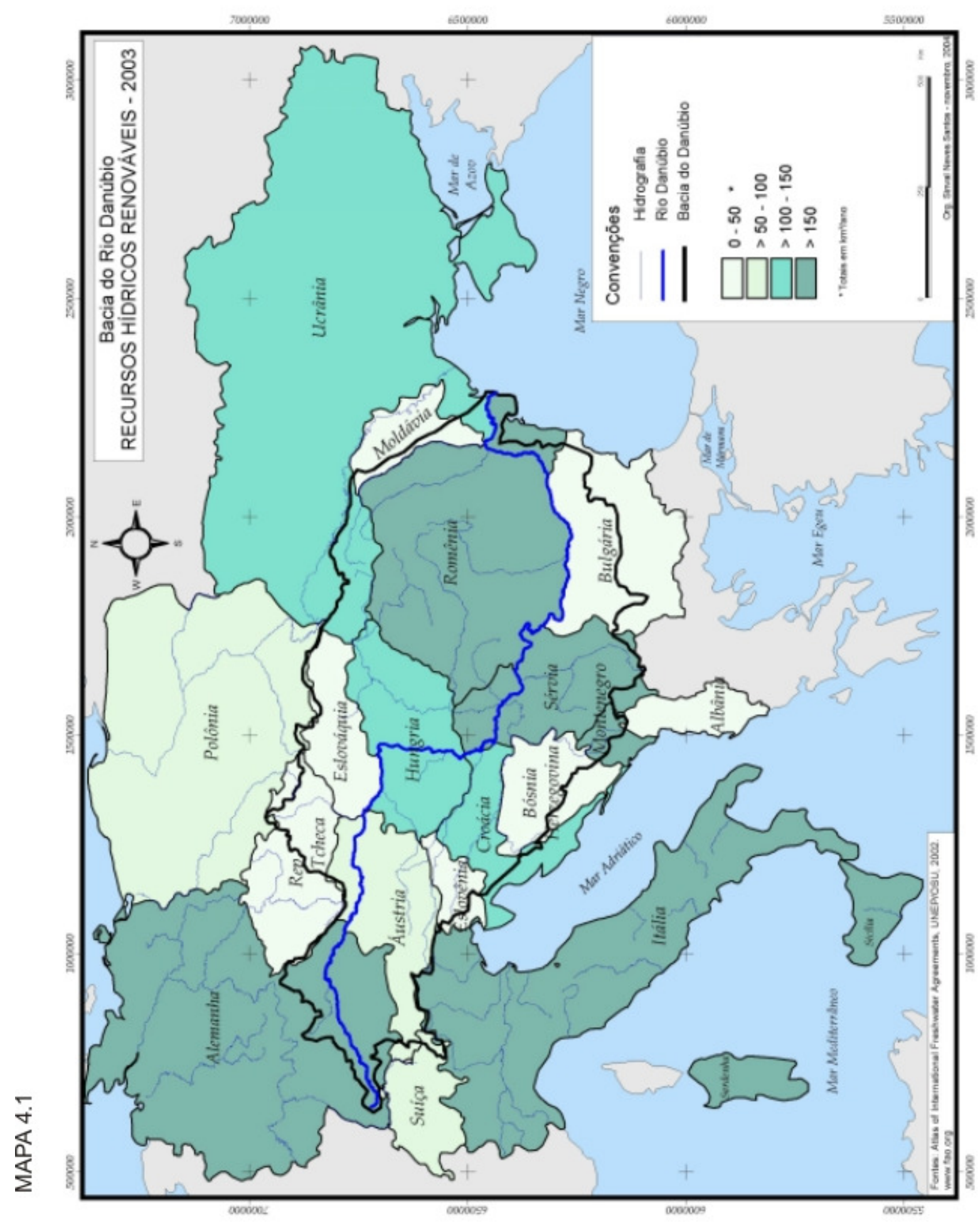


A partir deles constatamos que: Alemanha, Itália, República da Sérvia e Montenegro, além da Romênia possuem os maiores estoques hídricos dentro de suas respectivas fronteiras. Enquanto, República Tcheca, Eslováquia, Eslovênia, Bósnia-Herzegovina, Bulgária, Albânia e Moldávia encontram-se em situações menos confortáveis. O MAPA 4.1 também demonstra que Suíça, Itália, Albânia e Polônia possuem uma área desprezível dentro da bacia, tornando tais países atores secundários nas análises referente ao compartilhamento das ATS do rio Danúbio.

A dimensão e posição geográfica do rio Danúbio também Ihe confere um valor estratégico e econômico singular. Afinal ele representa uma das principais vias de ligação entre as porções Leste e Oeste do continente, apresentando ao longo dos séculos e nos dias atuais um papel vital no desenvolvimento político, econômico e social da Europa Central e Oriental.

Atualmente a população residente na bacia - superior a 81 milhões de pessoas - depende das águas do Rio Danúbio e tributários para os mais variados usos: abastecimento público, agricultura, indústria, transporte, turismo e recreação. $\mathrm{O}$ uso industrial, incluindo a geração de energia, destaca-se devido à quantidade significativa de empregos e renda gerados (ICPDR, 2004).

Como todos os demais grandes rios da Europa o Danúbio foi significativamente alterado e a afetou atividades humanas ao longo da história. Os primeiros diques de proteção de inundações foram construídos no século XVI dentro da Hungria. As maiores obras de regulação se iniciaram em 1830, na Áustria superior; a primeira represa hidrelétrica foi construída em 1927, na Baviera inferior.

Nos dias atuais, as obras hidráulicas na forma de reservatórios são encontradas predominantemente nas áreas montanhosas da bacia do Danúbio, enquanto a maioria dos canais de navegação, diques e redes de irrigação se concentram nas planícies ao longo dos cursos médio e baixo do rio. Mais de $80 \%$ da extensão do rio Danúbio é regulada; sobre ele e seus principais afluentes foram construídas mais de 700 represas e barragens (ICPDR, 2004).

Além de ter suas águas aproveitadas para a produção de energia hidrelétrica, o Danúbio é intensamente navegável, constituindo-se numa das principais artérias comerciais da Europa. Navios podem trafegar por $2411 \mathrm{~km}-87 \%$ do curso total - 
onde existem 78 portos. Por ser um rio que cruza territórios de muitos países, desde o Tratado de Paris (1856), o Danúbio tem sua navegação liberada para embarcações de qualquer origem.

Os fluxos comerciais na região se intensificaram com a entrada em operação da interligação Danúbio-Meno-Reno, em 1992. Trata-se de um canal com 171 km de extensão, que permite ligar Roterdã, no mar do Norte, ao porto romeno de Constança, no mar Negro, num total de $3500 \mathrm{~km}$ de vias fluviais navegáveis.

Em termos quantitativos as demandas hídricas da bacia são divididas entre os usos agrícolas, domésticos e industriais.

A TABELA 4.2 apresenta a distribuição do consumo hídrico dentro dos limites nacionais de cada país, segundo os tipos de uso.

TABELA 4.2

\begin{tabular}{|l|r|r|r|}
\hline \multicolumn{3}{|c|}{ Bacia do Rio Danúbio: Consumo Hídrico } \\
\hline \multicolumn{1}{|c|}{ Países } & \multicolumn{2}{|c|}{ Tipos de uso (em \%) } \\
\cline { 2 - 3 } & Agrícola & Doméstico & Industrial \\
\hline Albânia & 62 & 27 & 11 \\
\hline Alemanha & 20 & 12 & 68 \\
\hline Áustria & 1 & 35 & 64 \\
\hline Bósnia-Hezergovina & $\mathrm{n} / \mathrm{d}$ & $\mathrm{n} / \mathrm{d}$ & $\mathrm{n} / \mathrm{d}$ \\
\hline Bulgária & 19 & 3 & 78 \\
\hline Croácia & $\mathrm{n} / \mathrm{d}$ & $\mathrm{n} / \mathrm{d}$ & $\mathrm{n} / \mathrm{d}$ \\
\hline Eslováquia & $\mathrm{n} / \mathrm{d}$ & $\mathrm{n} / \mathrm{d}$ & $\mathrm{n} / \mathrm{d}$ \\
\hline Eslovênia & $\mathrm{n} / \mathrm{d}$ & $\mathrm{n} / \mathrm{d}$ & $\mathrm{n} / \mathrm{d}$ \\
\hline Hungria & 32 & 9 & 59 \\
\hline Itália & 45 & 18 & 37 \\
\hline Moldávia & 33 & 9 & 58 \\
\hline Polônia & 8 & 13 & 79 \\
\hline Rep. Tcheca & 2 & 41 & 57 \\
\hline Romênia & 57 & 9 & 34 \\
\hline Sérvia e Montenegro & $\mathrm{n} / \mathrm{d}$ & $\mathrm{n} / \mathrm{d}$ & $\mathrm{n} / \mathrm{d}$ \\
\hline Suíça & 2 & 24 & 74 \\
\hline Ucrânia & 52 & 12 & 35 \\
\hline
\end{tabular}

Fonte: FAO/ aquastat, 2003. 
A TABELA 4.2 reflete uma situação bastante diversificada, resultado das diferenças na estrutura econômica nos países da bacia. Albânia, Romênia, Itália e Ucrânia têm a maior parte de seu consumo destinado à irrigação. Enquanto os demais países destinam a maioria de suas reservas hídricas para o setor industrial. Também chama a atenção a lacuna de dados referentes a Bósnia-Herzegovina, Croácia, Eslováquia, Eslovênia, além da República Sérvia e Montenegro; tratam-se de países recentemente independentes e que ainda possuem severas limitações em suas instituições estatísticas nacionais.

Considerando-se a grande quantidade de Estados que compartilham uma única bacia, as diversas demandas por recursos hídricos e as variáveis geopolíticas que envolvem as relações entre tais Estados-nações, a bacia do rio Danúbio apresenta-se como um caso exemplar nos estudos sobre a solução de conflitos referente à partilha de águas transfronteiriças.

Passaremos então, a avaliação das interações interestatais ocorridas naquela bacia na última metade do século passado.

\subsection{Conflito e cooperação: um balanço}

Nossas pesquisas, realizadas a partir os registros do Transboundary Freshwater Dispute Database $\left(\right.$ TFDD) ${ }^{38}$, permitiram analisar os eventos relacionados ao compartilhamento das ATS na bacia do rio Danúbio no período compreendido entre 1948 e 2000.

De acordo com os critérios do projeto BAR/TFDD - apresentados no capítulo anterior - foi registrado um total de 165 eventos, sendo 87 cooperativos e 62 conflitivos. O GRÁFICO 4.3 apresenta tais eventos, classificados pela escala BAR (que aparece detalhada no ANEXO I desse trabalho).

\footnotetext{
${ }^{38}$ Disponível em: <www.transboundaryfreshwater.orst.edu $>$. Acesso em 27 set 2005.
} 


\section{Eventos na Bacia do Rio Danúbio 1948-2000}

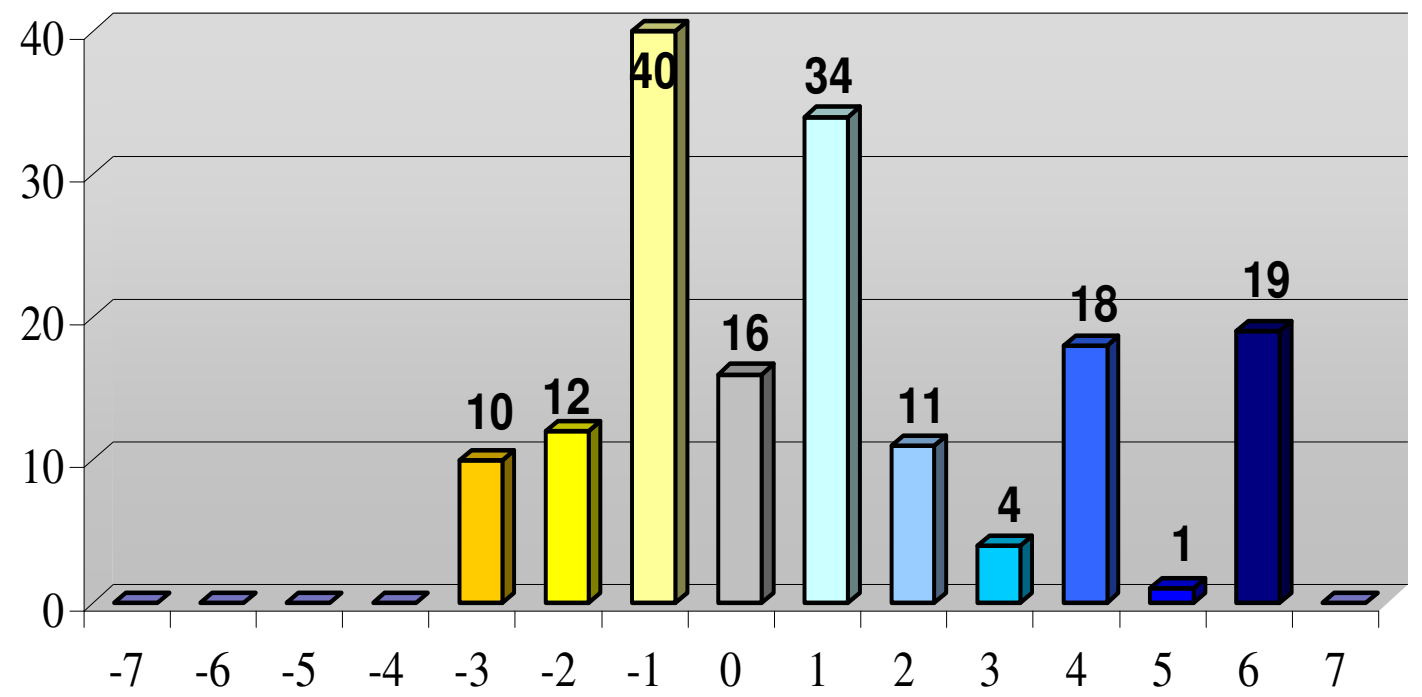

-7 Guerra formal

-6 Ações militares de grande escala

$\square-5$ Ações militares de pequena escala

$\square$-4 Ações políticas / militares hostis

-3 Ações diplomáticas / econômica hostis

-2 Hostilidade verbal forte / oficial

-1 Hostilidade verbal leve / não oficial

$\square 0$ Ações neutras / não significativas

1 Apoio verbal leve

$\square 2$ Apoio verbal oficial

$\square 3$ Acordo / apoio cultural científico

$\square 4$ Acordo não militar, econômico, tecnológico e industrial

$\square 5$ Apoio militar econômico e estratégico

$\square 6$ Tratado internacional de águas

$\square$ Unificação em uma nação

Fonte: TFDD. Disponível em: <www.transboundaryfreshwater.orst.edu $>$. Acesso em 27 set 2005. 
A proporção entre eventos cooperativos $(52,7 \%)$ e conflitivos $(37,5 \%)$ coloca a bacia do rio Danúbio em uma situação mais delicada que a média mundial, já que esta é de $67 \%$ para desfechos cooperativos e cerca de $28 \%$ para casos conflitivos, conforme demonstramos no capítulo anterior.

Os eventos considerados moderados (enquadrados entre -1 e 1) totalizam 90 casos, representando 54,5\%, valor superior à média mundial $(42,8 \%)$. Por outro lado, ficou constatado que as interações brandas, ou seja, aquelas em que a manifestação verbal leve por parte dos Estados substitui atitudes mais afirmativas, tanto no sentido da cooperação quanto do conflito, também é uma prática predominante na bacia do rio Danúbio.

Segundo tais registros, verificamos que os eventos conflitivos mais fortes foram manifestados por ações diplomáticas hostis (-3), enquanto as interações cooperativas mais intensas levaram os países a assinarem tratados internacionais sobre o tema $(+6)$.

GRÁFICO 4.4

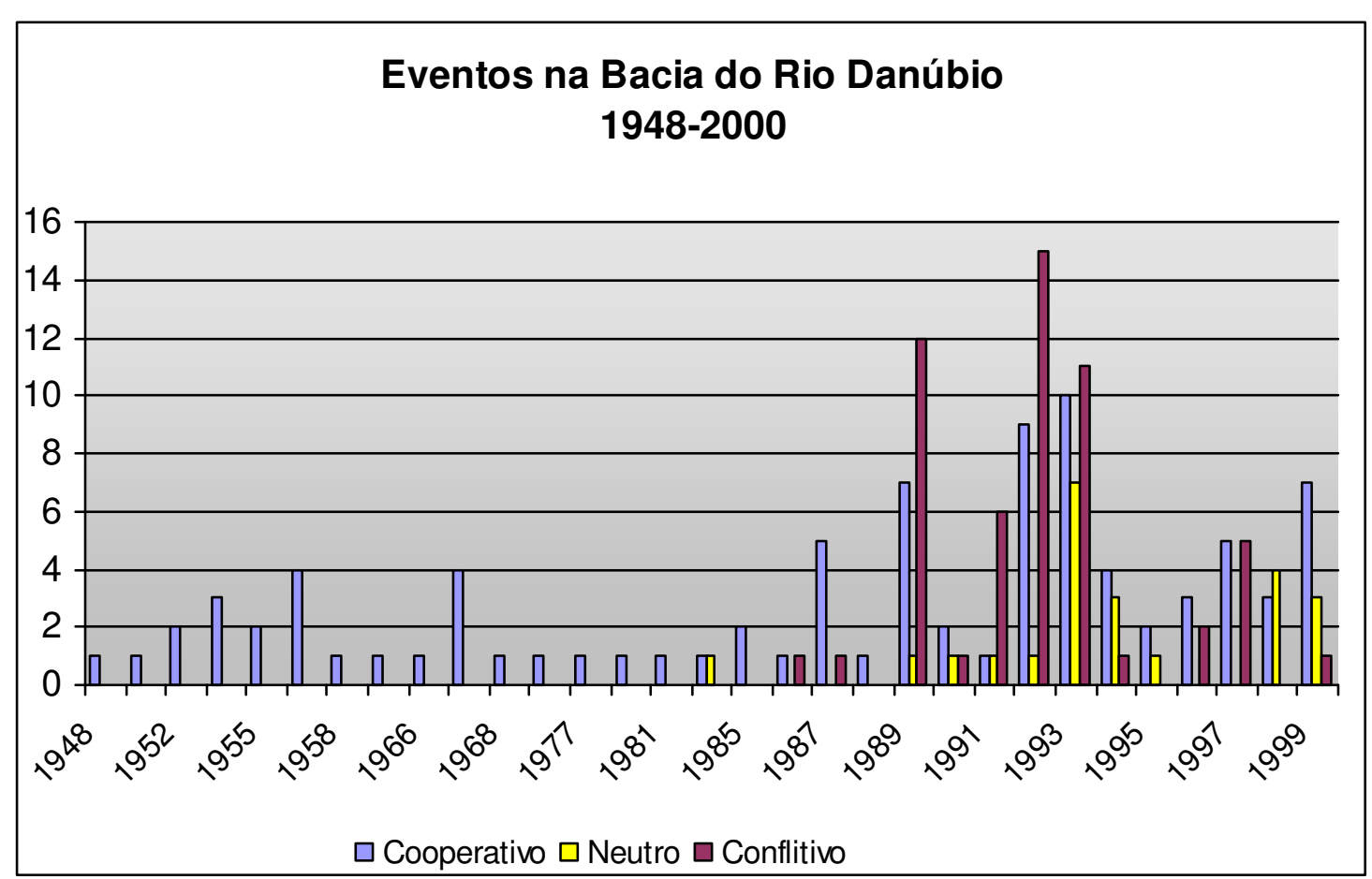

Fonte: TFDD. Disponível em: <www.transboundaryfreshwater.orst.edu $>$. Acesso em 27 set 2005. 
A distribuição dos eventos ao longo do tempo também foi considerada em nossa avaliação, o GRÁFICO 4.4 demonstra como ela ocorreu. Podemos observar uma nítida concentração, tanto de situações cooperativas quanto conflitivas, após o ano de 1989; neste período foram registradas 128 ocorrências, equivalente a 77,5\% do total.

Notamos que apesar de iniciativas cooperativas existirem desde o primeiro ano registrado pelo projeto BAR/TFDD, elas aumentam expressivamente sua intensidade no período pós 1987, com destaque para os anos 1989, 1992, 1993 e 1999. Já as ações conflitivas registradas, iniciam-se em 1987 e apresenta picos nos anos de 1989, 1992 e 1993.

No intuito de avaliarmos o potencial conflitivo da bacia concentramos nossa análise nos eventos desta natureza. A TABELA 4.3 apresenta a identificação dos Estados envolvidos nestes eventos:

TABELA 4.3

\begin{tabular}{|l|c|}
\hline \multicolumn{2}{|c|}{$\begin{array}{c}\text { Conflitos na Bacia do Rio Danúbio } \\
1948-2000\end{array}$} \\
\hline \multicolumn{1}{|c|}{ Países envolvidos } & Eventos \\
\hline Hungria x Eslováquia* & 52 \\
\hline Hungria x Croácia** & 05 \\
\hline Hungria x Áustria & 01 \\
\hline Romênia x lugoslávia & 02 \\
\hline Polônia x Eslováquia & 01 \\
\hline Bulgária x lugoslávia & 01 \\
\hline Total & 62 \\
\hline
\end{tabular}

*Tchecoslováquia, até 1992 **lugoslávia, até 1989 Fonte: TFDD. Disponível em: <www.transboundaryfreshwater.orst.edu $>$. Acesso em 27 set 2005. 
A análise da TABELA 4.3 e do GRÁFICO 4.5 evidencia que os desentendimentos entre Hungria e Eslováquia representaram as maiores preocupações dentro da bacia, os 52 eventos conflitivos registrados entre eles representam mais de $83 \%$ do total. Além disso, encontramos a Hungria em discordância com a Croácia e Áustria, ao todo a Hungria esteve envolvida em 58 casos, equivalente a $93 \%$ das situações conflitivas. Os eventos contabilizados pelo projeto BAR/TFDD permitem concluir que, apesar da prevalência das iniciativas cooperativas, a bacia do rio Danúbio não está livre de conflitos em torno do compartilhamento das ATS.

Em síntese, ao avaliarmos os casos de divergência notamos uma clara concentração tanto espacial: nos limites fronteiriços entre Hungria e Eslováquia, quanto temporal: no período pós guerra fria.

\section{GRÁFICO 4.5}

\section{Conflitos na Bacia do Rio Danúbio}

1948-2000

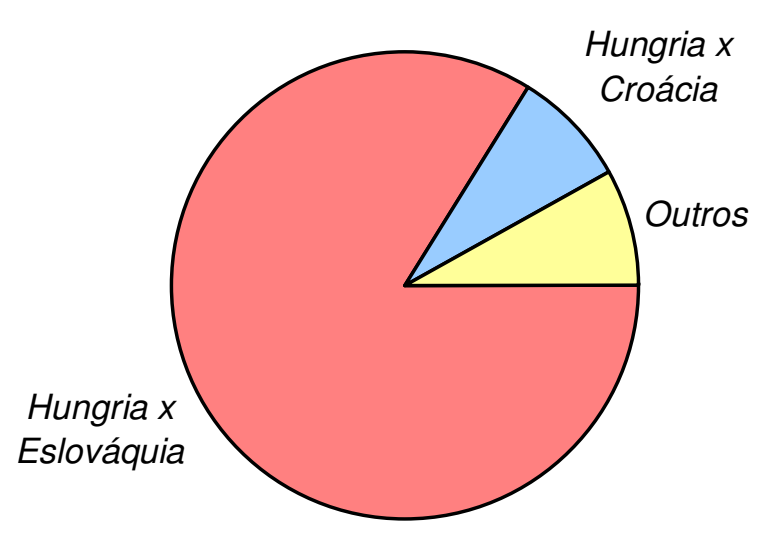

Fonte: TFDD. Disponível em: <www.transboundaryfreshwater.orst.edu> . Acesso em 27 set 2005 


\subsection{1 - As disputas entre Hungria e Eslováquia}

Assim, as disputas entre Hungria e Eslováquia ${ }^{39}$ passam a ter um papel central em nossa investigação. O GRÁFICO 4.6 apresenta as interações conflitivas entre os dois Estados distribuídas ao longo do tempo e classificadas segundo a escala BAR.

\section{GRÁFICO 4.6}

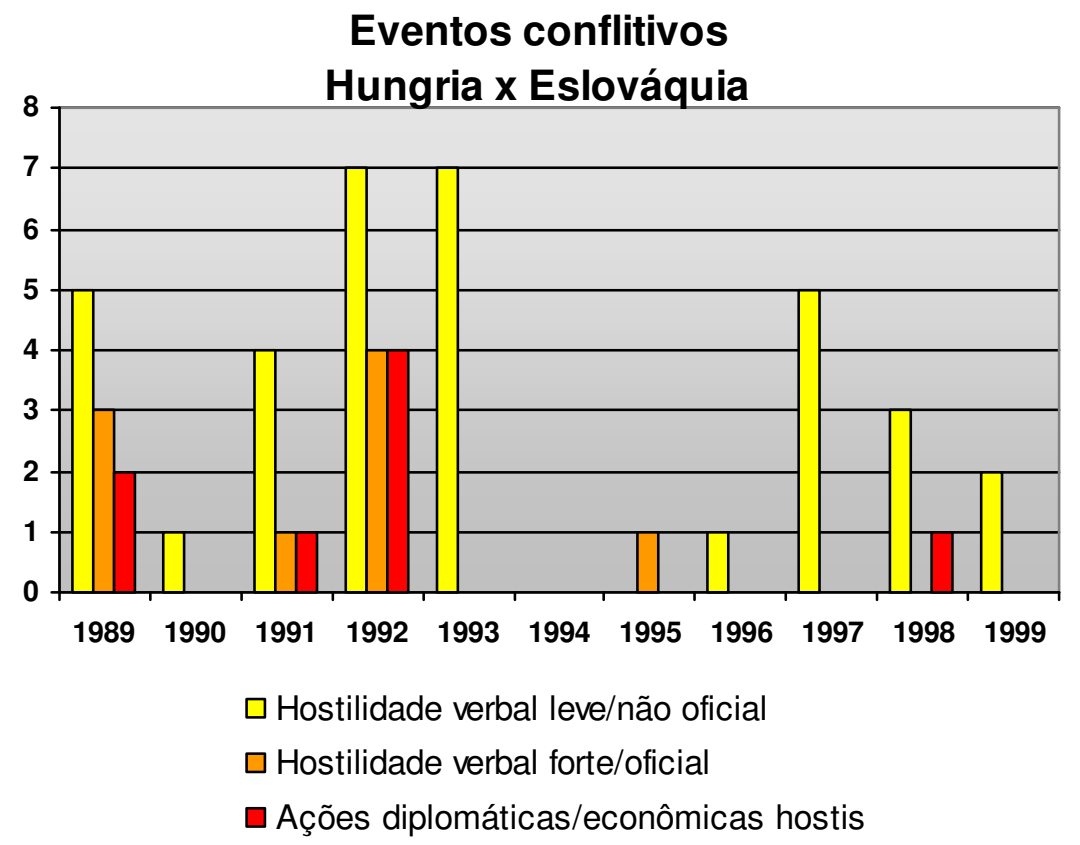

Fonte: TFDD. Disponível em: <www.transboundaryfreshwater.orst.edu $>$. Acesso em 27 set 2005

Constatamos que as desavenças relacionadas ao compartilhamento das ATS entre Hungria e Eslováquia se iniciaram em 1989 e atingiram o auge em 1992. Ainda segundo os registros do projeto BAR/TFDD, a maioria dos eventos $-67,3 \%$ deles foi classificada como hostilidades verbais leves / não oficiais e os mais críticos foram ações diplomáticas / econômicas hostis - em cerca de 15\% dos casos.

\footnotetext{
${ }^{39}$ As disputas envolveram inicialmente Hungria e Tchecoslováquia e posteriormente Hungria e Eslováquia. O desmembramento da Tchecoslováquia ocorreu, pacificamente, em função de diferenças étnicas e foi decidido durante o ano de 1992 e formalizado em 01/01/93.
} 
Os conflitos apontados no final da década de 1980 refletiam a discordância húngara em relação a um acordo sobre o uso compartilhado das águas do rio Danúbio, estabelecido com os eslovacos na década anterior.

Em 1977, a então Tchecoslováquia e a Hungria firmaram o Tratado sobre a Construção e Operação do Sistema de Barragens Gabcikovo-Nagymaros. Os objetivos do acordo eram: (1) produção de energia hidrelétrica - aproximadamente $20 \%$ das necessidades de energia elétrica de cada país; (2) redução da poluição do ar - com a diminuição da dependência de termelétricas alimentadas por carvão; (3) proteção de inundações; (4) construção de sistemas de irrigação e (5) melhoria das condições de navegação.

Tais objetivos seriam alcançados com a criação de um sistema de canais, barragens e usinas hidrelétricas: Gabcikovo em território da atual Eslováquia e Nagymaros em território húngaro. Para tanto, também estava prevista a construção, em Dunakiliti, de uma barragem sobre o Danúbio e um reservatório do lado eslovaco do limite fronteiriço, este seria alimentado por um canal de $17 \mathrm{~km}$ que desviaria $90 \%$ da vazão do rio, deixando no leito original apenas o mínimo. O mesmo seria feito $100 \mathrm{~km}$ à jusante com a barragem húngara. A conclusão destas obras foi fixada para o período compreendido entre 1986 e 1990 (MAPA 4.2).

Os trabalhos se iniciaram em 1978; mas, em 1981, os húngaros suspenderam sua participação devido a limitações financeiras. Nessa época já haviam surgido críticas de cunho ambiental por parte da sociedade civil organizada húngara e gradualmente o projeto passou a ser considerado como símbolo de decisões não pluralistas do governo húngaro. Mesmo assim, em fevereiro de 1989, foi assinado com a Tchecoslováquia um protocolo referente à aceleração das obras. Nesse momento a represa de Dunakiliti já estava $90 \%$ concluída, a represa de Gabcikovo $85 \%$ e restavam $60 \%$ das obras para conclusão de Nagymaros. 


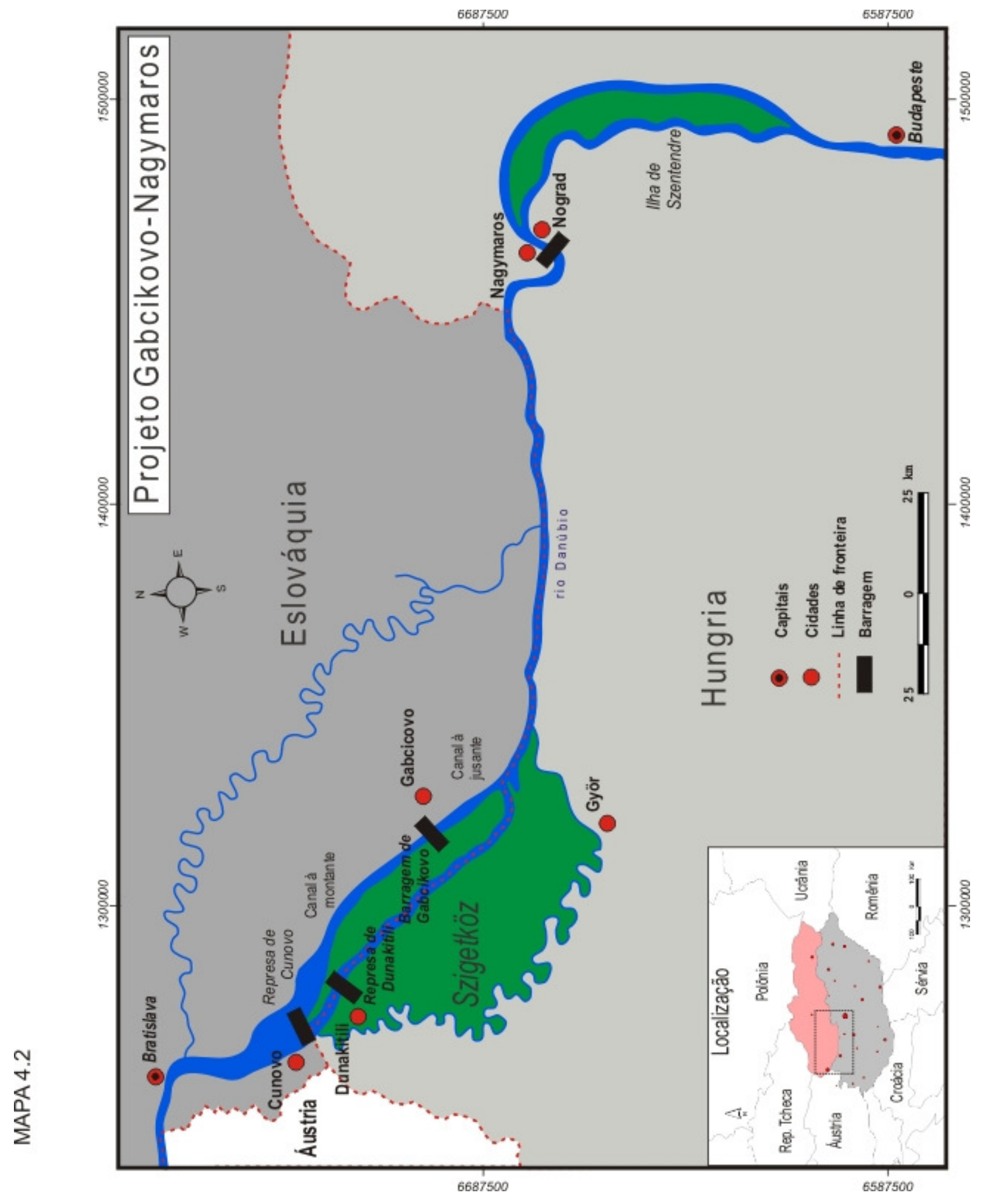


Numa grande guinada, em maio de 1989, o governo húngaro decidiu suspender unilateralmente a construção do projeto. Suas alegações oficiais se baseavam em questões ambientais ${ }^{40}$, embora a medida tenha sido claramente incentivada pelo amplo descontentamento público; além disso, as dificuldades econômicas eram notórias. Em outubro do mesmo ano, o Parlamento húngaro votou a favor de abandonar completamente os trabalhos de Nagymaros e suspender trabalhos de Dunakiliti.

Em resposta, especialistas eslovacos propuseram sete variantes ao projeto, sendo a "variante C" a escolhida pelo governo eslovaco. Essa solução implica em concluir a estação hidrelétrica de Gabcikovo com um reservatório menor, localizado exclusivamente sobre território eslovaco; essa variante exclui a represa de Dunakiliti e impunha um significativo desvio do rio Danúbio para dentro do território eslovaco.

Após negociações fracassadas, em 1991, a Hungria requereu a revogação do Tratado de 1977; por seu turno a então Tchecoslováquia rejeitou o cancelamento do acordo e passou a implementar a "variante C" de forma unilateral. No ano seguinte, a intransigência ainda persistia: em maio, a Hungria definitivamente decidiu pela revogação do Tratado de 1977; enquanto a Tchecoslováquia completou a represa de Cunovo (a montante de Dunakiliti) e iniciou o desvio do rio em 24 outubro. No dia seguinte, o gabinete húngaro se reuniu numa sessão de emergência para deliberar sobre a questão. Assim, o ano de 1992 representou o auge do litígio, conforme os registros do estudo BAR/TFDD ilustrados pelo GRÁFICO 4.6.

Imediatamente negociadores da então Comunidade Econômica Européia (CEE) embarcaram para Praga e Budapeste para retomar as negociações e evitar um desfecho violento do conflito ${ }^{41}$. As novas rodadas de negociações, iniciadas em 28 de outubro, culminaram com assinatura do Protocolo de Londres que determinava: (1) que a "variante C" seria colocada em compasso de espera, com exceção das obras necessárias à de prevenção de enchentes, à navegação segura

\footnotetext{
${ }^{40}$ Entre os principais temores ambientais citados estavam as, potencialmente, irreversíveis mudanças na diversidade biológica do ecossistema Szigetkoz (vide mapa 4.2) e o impacto no sistema de água subterrânea.

${ }^{41}$ Peter Gleick, em Water Conflict Chronology, registrou sobre o episódio: "maciços protestos públicos e movimento de militares para a fronteira envolvida". Disponível em $<$ www.worldwater.org/conflictchronology.html $>$. Acesso em out 2005.
} 
e à proteção do meio ambiente; (2) que o rio permaneceria com um fluxo de $95 \%$ no seu leito original e (3) que a hidrelétrica de Gabcikovo não seria ativada.

Também ficou decidido que a questão seria encaminhada para a Corte Internacional de Justiça (ClJ), sediada em Haia, tornando-se a primeira demanda jurídica referente ao meio ambiente arbitrada por essa instância. Assim, o caso Gabcikovo-Nagymaros se tornou emblemático, despertando o interesse da comunidade internacional, especialmente daqueles países envolvidos em litígios sobre ATS. Por isso, Turquia e Síria enviaram observadores a CIJ, enquanto Egito, Israel e Jordânia acompanharam atentamente a evolução do caso.

Fuyane e Madai (2001) avaliam que o princípio de sustentabilidade fundamentou as reivindicações húngaras perante a Corte, enquanto o direito ao desenvolvimento estava nos argumentos da Tchecoslováquia. Foi diante dessa polarização que o Tribunal de Haia teve de tomar sua decisão.

O veredicto, divulgado em setembro de 1997, define que:

(a) a Hungria não tinha o direito de suspender e posteriormente abandonar, em 1989, as obras do Projeto Nagymaros e parte do Projeto Gabcikovo;

(b) a decisão húngara de revogar o Tratado de 1977, de maio de 1992, não tem efeito legal;

(c) a Tchecoslováquia tinha o direito de proceder a "solução provisória" (variante C), em novembro de 1991;

(d) a Tchecoslováquia não tinha o direito de colocar a "solução provisória" em operação, a partir de outubro de 1992;

(e) a Hungria deverá compensar a Eslováquia pelos danos sofridos pela suspensão e abandono dos trabalhos que eram de responsabilidade daquele país;

(f) a Eslováquia deverá compensar a Hungria pelos danos causados por ter colocado em operação a "variante C" (ICJ, 1997).

Além disso, o Tribunal exigiu que os dois governos negociassem uma solução ambientalmente válida, se não conseguissem elaborá-la a disputa seria levada à ONU (VILLIERS, 2002).

A decisão da Corte de Haia deixou ambas as Partes insatisfeitas, fato que justifica a ocorrência de eventos conflitivos mesmo após 1997, conforme 
demonstrado no GRÁFICO 4.6. Ao analisar os registros do projeto BAR/TFDD, constatamos divergências relativas às interpretações da sentença, às medidas compensatórias, às alternativas para conclusão do projeto e à quantidade de água. Porém, o risco de um conflito violento foi afastado e as difíceis negociações continuaram.

Em 28 de fevereiro de 1998 foi finalmente assinado um Memorando de Entendimento, que acordava 4 pontos principais:

(a) o nível da represa de Dunakiliti deverá ser elevado a 128m acima do nível do mar (possibilitando a regulação do volume de água no rio Danúbio, estimulando os necessários mecanismos de transbordo e inundações);

(b) o reservatório de Cunovo deverá ser adaptado ao inventário do projeto original;

(c) uma represa deverá ser construída em Nagymaros ou em Pilismarót, e

(d) as partes renunciaram todas as demandas financeiras.

No entendimento de Fuyane e Madai (2001) as decisões do memorando equilibram a utilização da água, contemplando os aspectos ecológicos e de produção energética. Para eles, este acordo, apesar de possuir um caráter provisório, foi um marco na reconciliação de interesses entre as Partes.

Como já argumentamos, estamos convencidos da relevância dos fatores geográficos e políticos nas discussões pertinentes a gestão das ATS. Portanto, para concluir nossa análise do caso Gabcikovo-Nagymaros, apresentaremos uma avaliação de tais fatores na bacia do rio Danúbio, com especial atenção para a situação dos Estados protagonistas ${ }^{42}$ dessa iniciativa de compartilhamento. Com esses objetivos, realizaremos um diagnóstico das variáveis territoriais e das variáveis políticas, conforme definimos no capítulo anterior.

\footnotetext{
${ }^{42}$ Como já adiantamos, esses Estados foram inicialmente Hungria e Tchecoslováquia e posteriormente Hungria e Eslováquia. O desmembramento da Tchecoslováquia ocorreu, pacificamente, em função de diferenças étnicas e foi decidido durante o ano de 1992 e formalizado em 01/01/93. Realizaremos nossa avaliação utilizando o território da Eslováquia como unidade análise, em função de sua relação direta com o rio Danúbio e porque durante o auge do conflito - outubro de 1992- a divisão já estava definida.
} 


\subsection{As variáveis territoriais}

Definimos como variáveis territoriais àquelas relacionadas diretamente à oferta e demanda hídrica dentro da bacia, tratam-se de indicadores resultantes de diversos fatores naturais, sociais e econômicos que se sintetizam fisicamente no território.

Para diagnosticar as variáveis territoriais que possuem relação com 0 as interações interestatais conflitivas da bacia do Danúbio, em especial aquelas envolvendo Hungria e Eslováquia, utilizaremos os quatro indicadores de vulnerabilidade apontados pelo geógrafo Peter Gleick (1994) e analisados no capítulo 3 dessa dissertação.

Como demonstramos, tais indicadores enfatizam componentes físicos do sistema (água e energia) e utilizam os limites nacionais como unidade de análise. Critérios coerentes com a premissa desse trabalho, fundamentada nos postulados do geógrafo Wagner Ribeiro (2001) que identifica o predomínio da defesa dos interesses nacionais - incluindo a defesa dos estoques de recursos naturais, como a água - na OAl que está em construção.

Um dos indicadores mencionados por Gleick (1994) é apresentado no GRÁFICO 4.7. Trata-se da relação entre utilização e provisão dos recursos hídricos, esse índice é alcançado dividindo-se a demanda anual de água pela disponibilidade de água renovável de um país. O relatório Global Environment Outlook 2000 publicado pelo Programa das Nações Unidas para o Meio Ambiente, em 1999 define este indicador como estresse hídrico, adotando a seguinte classificação:

- elevado: quando são usados $40 \%$ ou mais dos recursos hídricos renováveis;

- médio alto: quando são utilizados de 20 a $40 \%$ dos recursos hídricos renováveis;

- moderado: quando são utilizados de 10 a 20\% dos recursos hídricos renováveis; e

- baixo: quando são utilizados menos que 10\% dos recursos hídricos renováveis (UNEP, 1999:42). 
GRÁFICO 4.7

\section{Bacia do Rio Danúbio \\ ESTRESSE HÍDRICO - 2003}

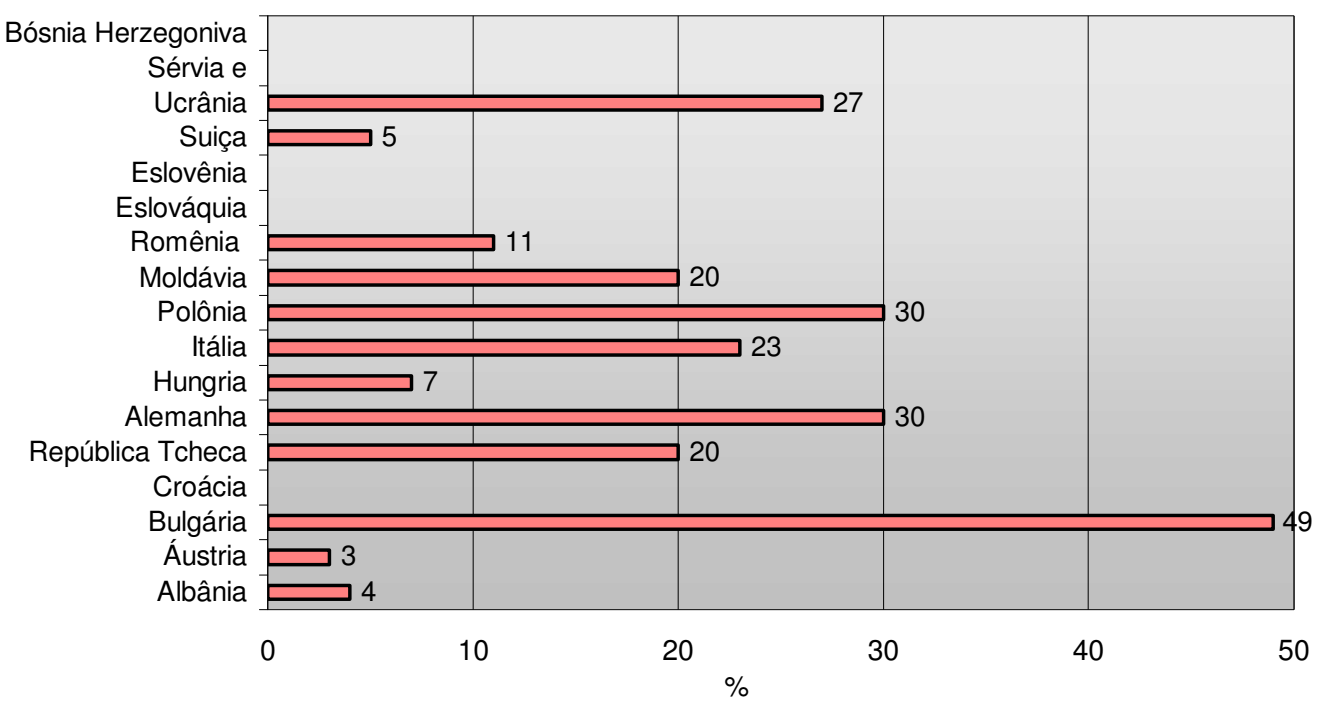

fonte: FAO / aquastat, 2003.

\section{GRÁFICO 4.8}

\section{Bacia do Rio Danúbio DISPONIBILIDE HÍDRICA - 2003}

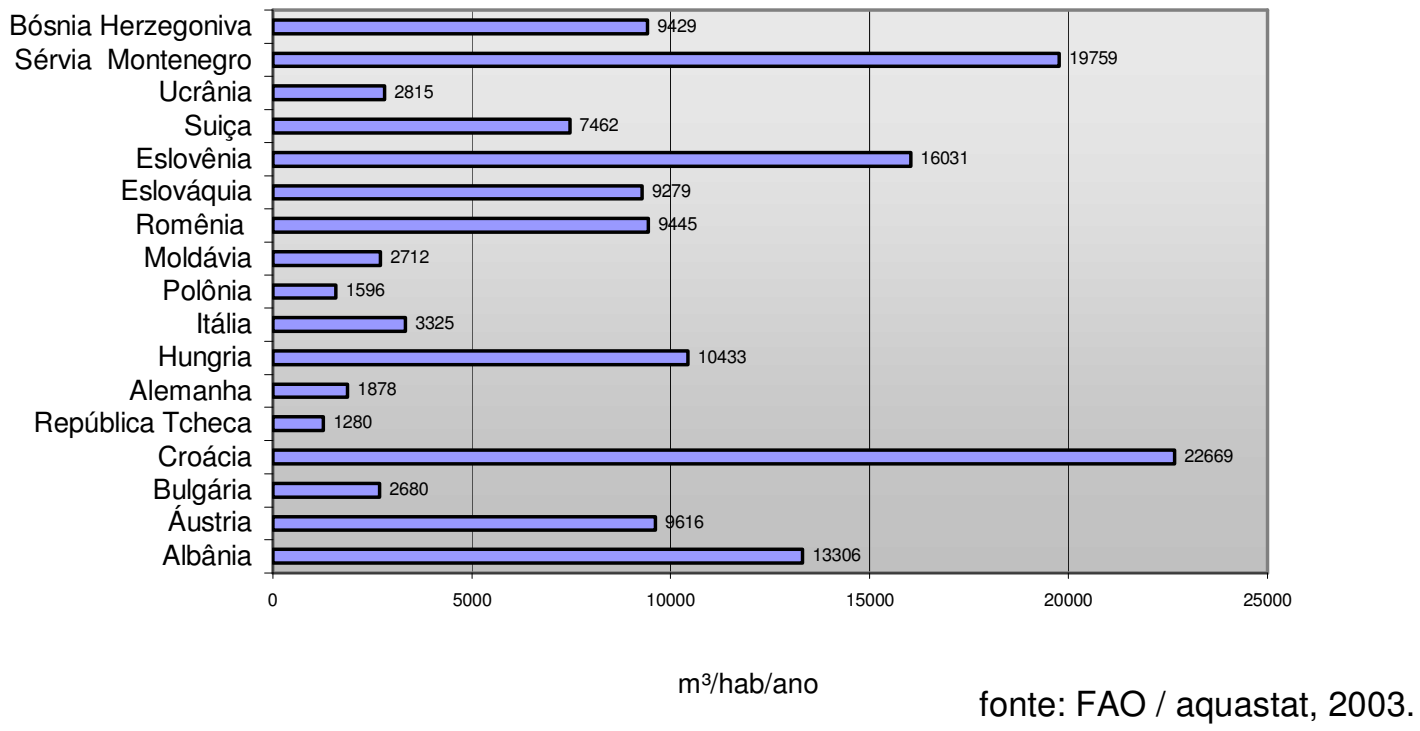




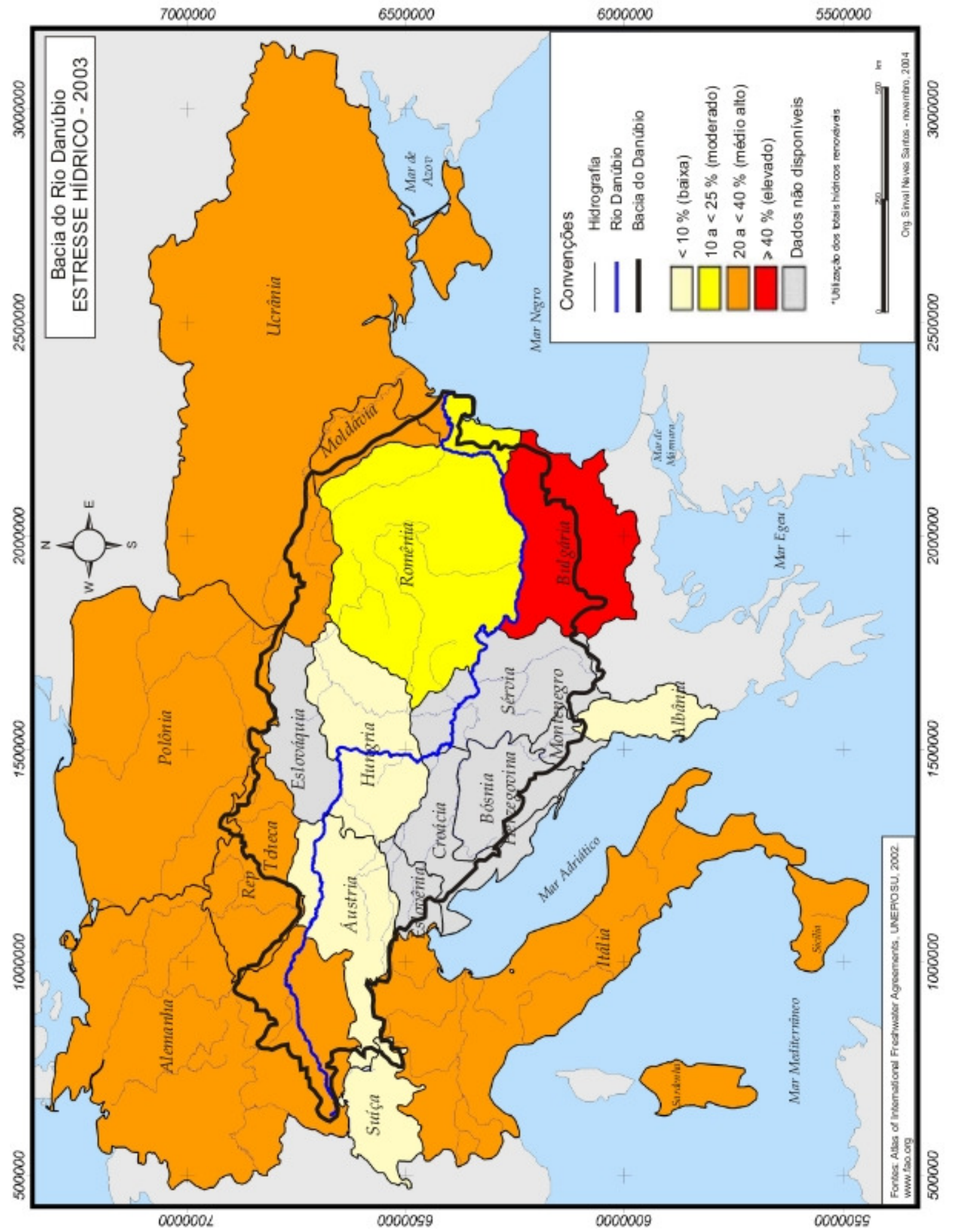


Gleick (1994) afirma que a escassez resultante de um fornecimento limitado frente a uma elevada demanda pode levar a conflitos. Assim constatamos, com o auxílio do mapa 4.3, que a Romênia é o país em situação mais delicada, já que possui um estresse hídrico considerado elevado. Enquanto Itália, Alemanha, Polônia e Ucrânia encontram-se em situação de alerta, pois estão enquadrados no nível médio alto, segundo os critérios do PNUMA.

Sob esse aspecto, a Hungria se encontra em uma situação confortável, já que utiliza apenas $7 \%$ de sua disponibilidade hídrica, índice que caracteriza um baixo estresse hídrico. Por limitações das instituições estatísticas nacionais, os dados referentes à Eslováquia não estão disponíveis.

Outro indicador relevante, segundo Gleick (1994), é a disponibilidade hídrica, que pondera os totais de recursos hídricos renováveis anuais em relação aos habitantes de cada país. O GRÁFICO 4.8 apresenta a situação dos países integrantes da bacia do Danúbio, segundo esse quesito.

O relatório Global Environment Outlook 3 - publicado pelo Programa das Nações Unidas para o Meio Ambiente, em 2002 - apresenta 6 classes para esse indicador:

- catastroficamente baixa: $<1000 \mathrm{~m}^{3}$ per capita, por ano;

- muito baixa: 1.000 a $2.000 \mathrm{~m}^{3}$, per capita, por ano;

- baixa: > 2.000 a $5.000 \mathrm{~m}^{3}$, per capita, por ano;

- média: > 5.000 a $10.000 \mathrm{~m}^{3}$, per capita, por ano;

- alta: > 10.000 a $20.000 \mathrm{~m}^{3}$, per capita, por ano;

- muito alta: >20.000 m³ , per capita, por ano (UNEP, 2002:152).

Utilizando tais critérios O MAPA 4.4, apresenta a disponibilidade hídrica da Bacia do Rio Danúbio, em 2003. A partir dele constatamos que os cenários mais críticos estão na Alemanha, Polônia e República Tcheca, já que possuem uma disponibilidade considerada muito baixa. Além disso, Itália, Bulgária, Moldávia e Ucrânia também apresentam situações preocupantes, classificadas como de baixa disponibilidade hídrica. 


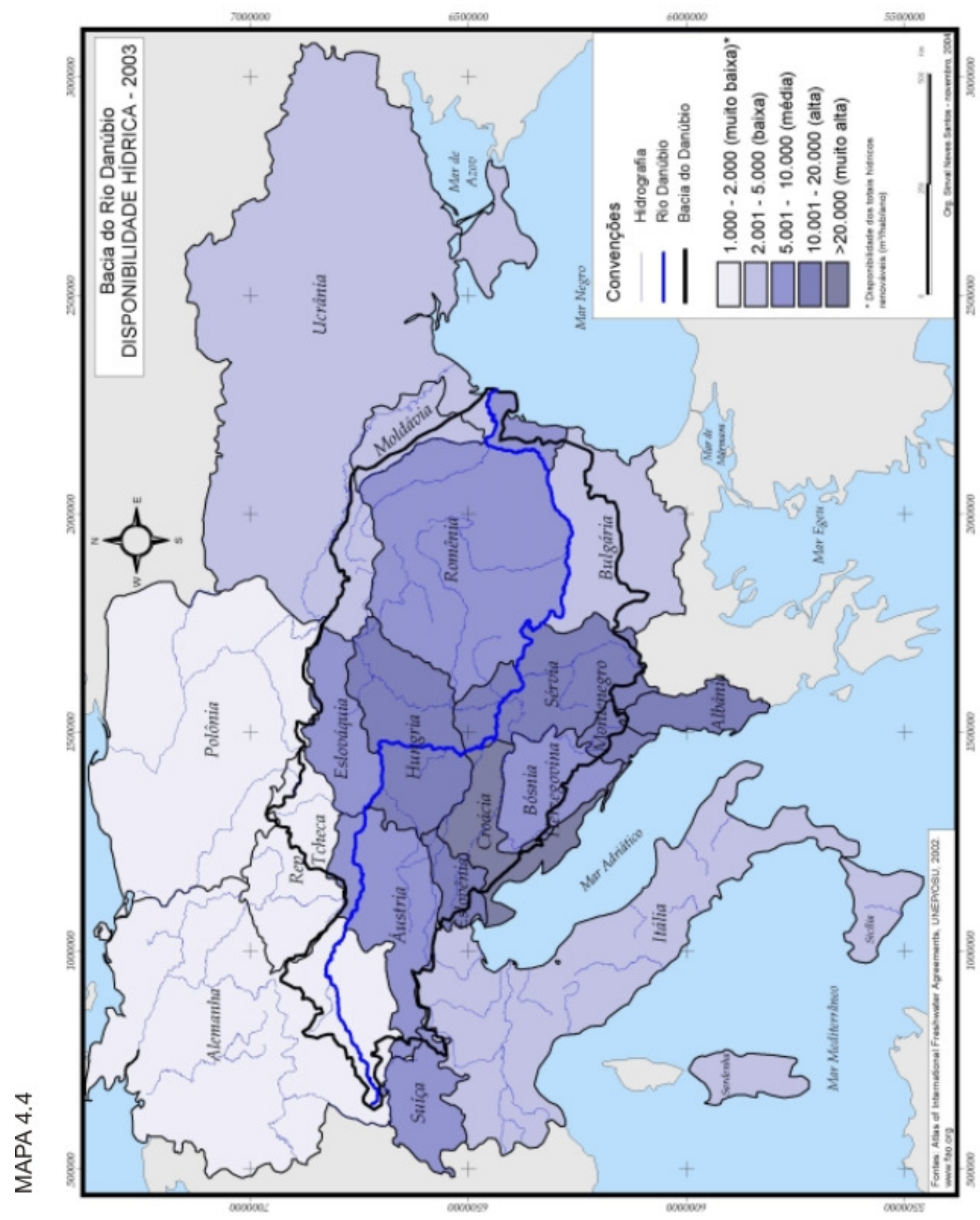


Sob esse aspecto os cenários da Eslováquia e da Hungria também não se mostram alarmantes. Como podemos observar no GRÁFICO 4.8, a Hungria possui uma disponibilidade hídrica um pouco mais elevada; classificada como alta, segundo os critérios do PNUMA. No MAPA 4.4 a Eslováquia aparece na classe de disponibilidade hídrica média, porém o índice de $9.279 \mathrm{~m} 3 / \mathrm{hab} / \mathrm{ano}$ está muito próximo da classe superior (alta).

Gleick (1994) defende que a vulnerabilidade de um país também pode ser relacionada à dependência hídrica externa, ou seja, a parcela dos recursos hídricos de cada país que provém de fora de suas fronteiras. Uma das formas de mensurar essa variável é relacionar o eventual déficit de recursos hídricos ${ }^{43}$ com o total de recursos hídricos renováveis de um país. O GRÁFICO 4.9 registra tais resultados para os países da bacia do rio Danúbio, em 2003.

Ao se referir a este índice de vulnerabilidade Gleick (1994) destaca os países que possuem uma dependência superior a $30 \%$. A partir deste critério criamos 5 classes, que subsidiaram a elaboração e a interpretação do MAPA 4.5, a saber:

- nula / muito baixa: $0-10 \%$

- baixa / moderada: $>10-30 \%$

- alta: $>30-50 \%$

- muito alta: $>50 \%$

- extremamente alta: $>70 \%$

Para Gleick (1994) quanto maior a dependência hídrica externa maior a vulnerabilidade, devido ao aumento potencial de interesses e concorrências sobre os recursos hídricos. Sob este prisma o cenário traçado para a bacia do rio Danúbio é especialmente delicado, visto que mais da metade dos países (10) possuem uma dependência superior a $30 \%$, considerada alta. Como podemos constatar no MAPA 4.5, são cinco os países que possuem dependência extremamente alta: Eslováquia, República da Sérvia e Montenegro, Romênia, Moldávia e Hungria. Destacando estes dois últimos por possuírem uma dependência externa superior a 90 por cento!

\footnotetext{
${ }^{43}$ Ponderado entre a quantidade dos recursos hídricos renováveis internos e o total dos recursos hídricos renováveis.
} 
Gráfico 4.9

\section{Bacia do Rio Danúbio: \\ DEPENDÊNCIA HÍDRICA EXTERNA - 2003}

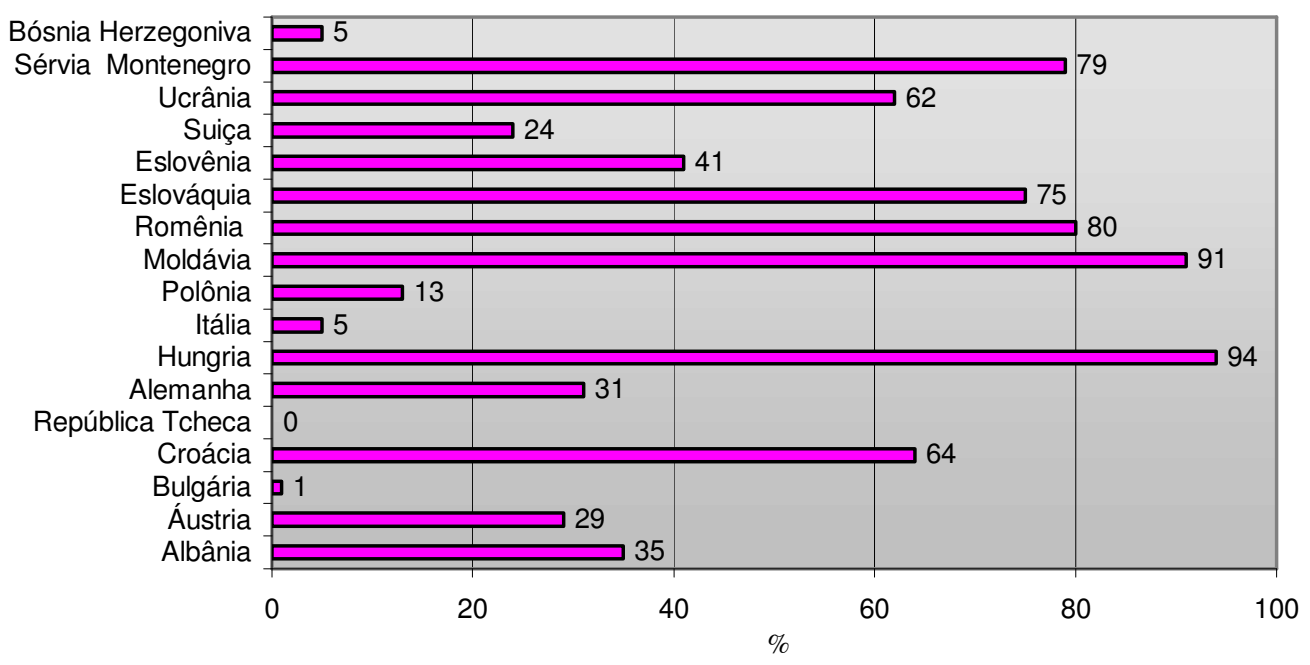

fonte: FAO / aquastat, 2003.

Gráfico 4.10

\section{Bacia do Rio Danúbio \\ DEPENDÊNCIA HIDRELÉTRICA - 2002}

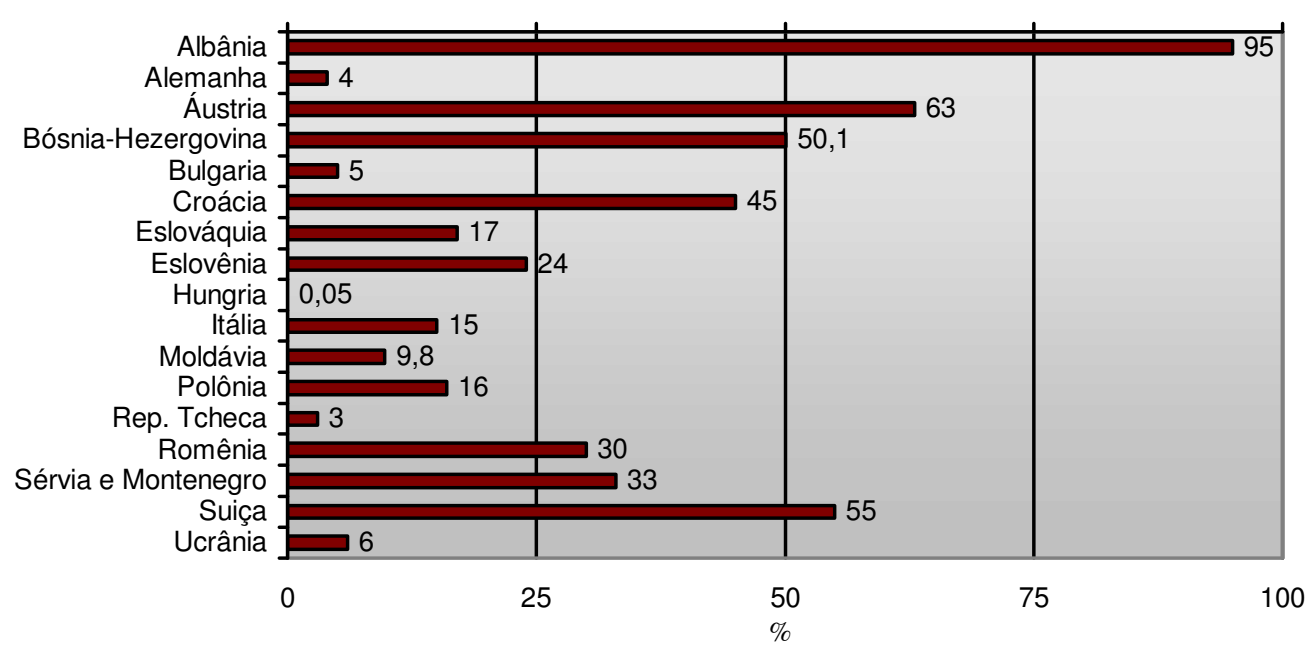

Fonte: EIA - Energy Information Administrataion - US Government, 2002. 


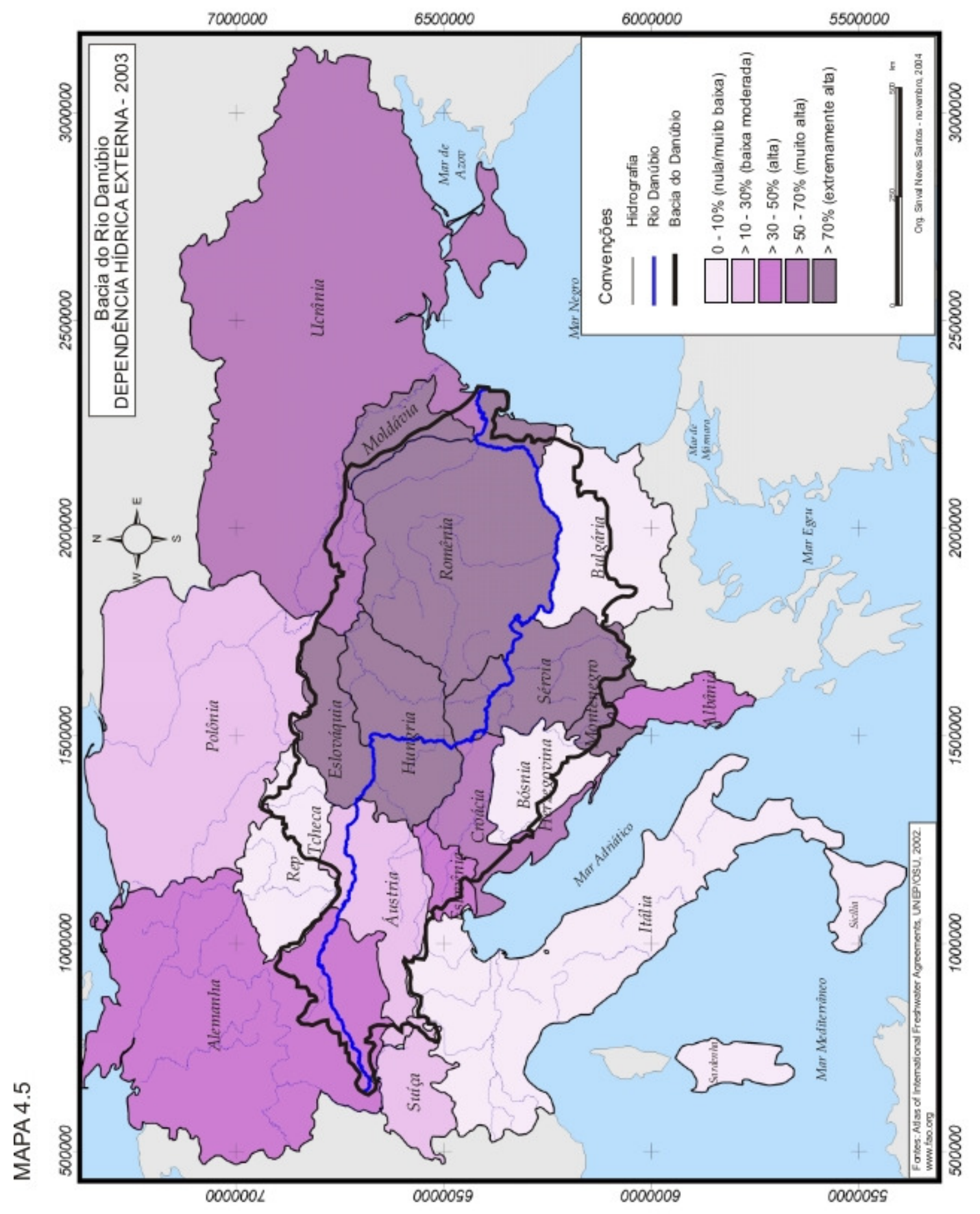


Este indicador apresenta forte relação com a concentração dos eventos conflitivos entre Hungria e Eslováquia, já que ambos se encontram em uma situação de dependência hídrica externa classificada como extremamente alta.

A análise do MAPA 4.5 permite-nos concluir que a posição geográfica dos países é o fator preponderante na definição do nível de dependência hídrica externa. Como podemos observar os países com dependência "extremamente alta" possuem uma grande parcela de seu território inseridos na bacia e se localizam no médio ou baixo curso do rio Danúbio, o que os torna subordinados aos fluxos de montante.

O caso da Hungria é emblemático. Como podemos constatar no GRÁFICO 4.9 se trata do país em situação mais grave, já que $94 \%$ de seus recursos hídricos renováveis provém de fora de suas fronteiras. Esta dependência quase absoluta reflete duas circunstâncias geográficas do território húngaro: (1) estar integralmente inserido na bacia e (2) estar localizado em seu médio curso.

O quarto indicador de vulnerabilidade apontado por Gleick (1994) é a dependência de energia hidrelétrica, que reflete a participação da água no total de energia elétrica gerada em um país. Segundo o geógrafo estadunidense, quanto maior a dependência, maior a probabilidade de um Estado envolver-se em disputas relacionadas a ATS, por isso ele manifesta preocupação com aqueles países nos quais a hidreletricidade responde por mais de $50 \%$ da geração elétrica. O GRÁFICO 4.10 apresenta esse indicador para os países da bacia do Rio Danúbio, em 2002.

O MAPA 4.6 representa a dependência de energia hidrelétrica na bacia do rio Danúbio. Considerando as preocupações de Gleick (1994), criamos 5 classes que nos subsidiaram na elaboração e interpretação do mapa, a saber:

- muito baixa: 0-10\%

- baixa: > 10-25\%

- média: > 25-50\%

- elevada: $>50-75 \%$

- muito elevada: $>75 \%$. 


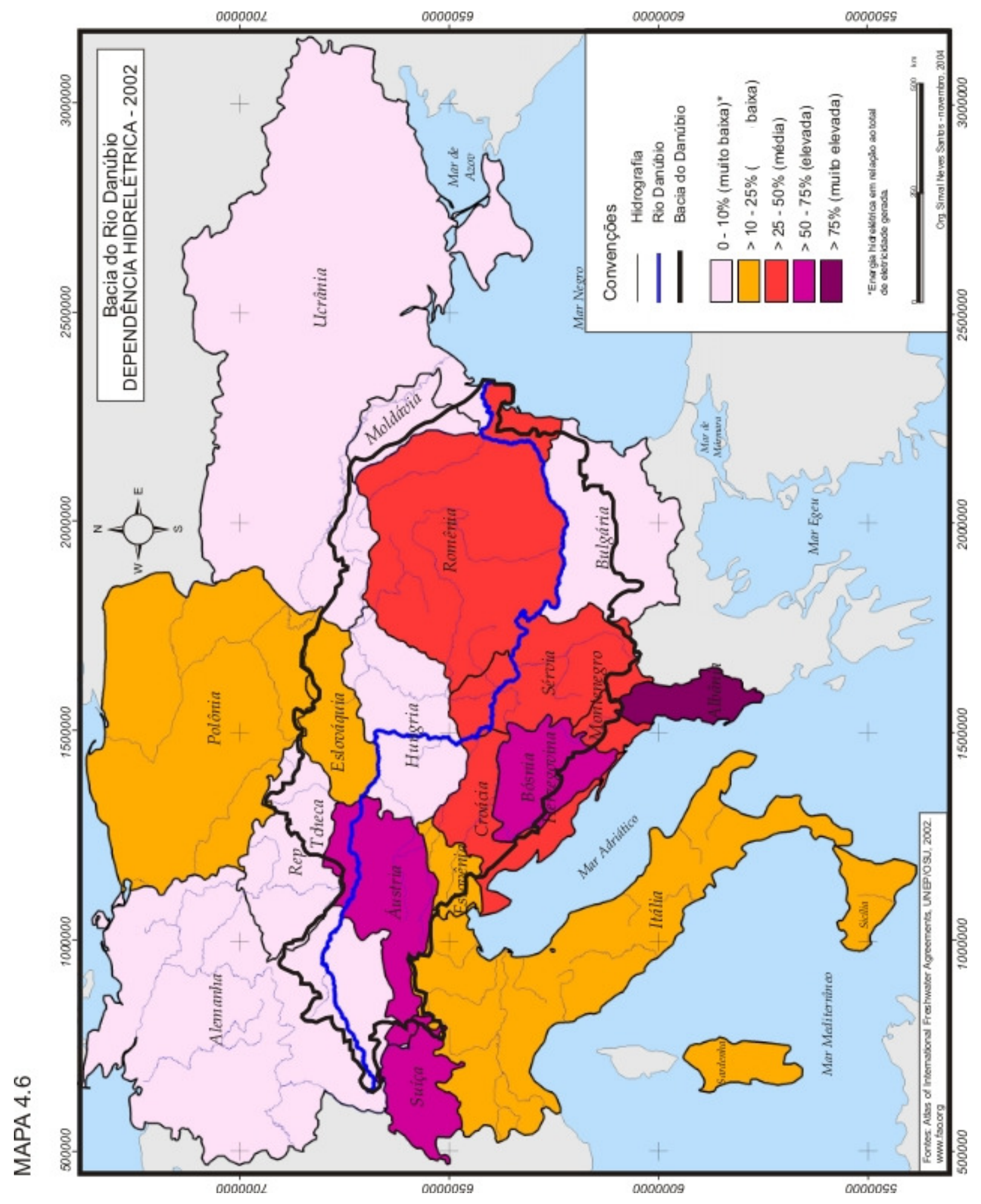


Nesse quesito, a situação da bacia pode ser considerada confortável, já que a maioria dos Estados - 10 deles - possui uma dependência muito baixa ou baixa. Enquanto apenas quatro países se encontram em situação de preocupação: Áustria, Bósnia e Suíça, com elevada dependência, além da Albânia com dependência muito elevada. Este último, apesar da participação quase absoluta da energia hidrelétrica (95\%), não deve apresentar relações desse indicador com eventos conflitivos na bacia do Danúbio, pois a parcela de seu território dentro desta bacia é inexpressiva (apenas $200 \mathrm{~km}^{2}$ ).

Se considerarmos a preocupação de Gleick (1994) em relação à dependência hidrelétrica, não encontraremos uma relação significativa entre esse indicador de vulnerabilidade e os dois principais protagonistas dos eventos conflitivos na bacia. A Eslováquia apresenta uma baixa dependência hidrelétrica, já que essa equivale a $17 \%$ da geração de eletricidade, a principal fonte do país é a energia nuclear, respondendo por 55,9\%. Enquanto na Hungria a participação da hidreletricidade é praticamente nula; em 2002, a água foi responsável por apenas $192 \mathrm{Kwh}$ de um total de $34.061 \mathrm{Kwh}$ gerados. A matriz energética húngara está baseada nas fontes termelétricas convencionais, que produziram no mesmo período $60,3 \%$ da energia elétrica do país (EIA-US).

Mas se analisarmos esse indicador por outra perspectiva, é possível estabelecer uma relação entre a produção de eletricidade e as interações que envolveram Hungria e Tchecoslováquia. Como vimos, a produção de energia hidrelétrica foi um dos pontos centrais do Tratado de 1977, a partir do qual estavam previstos ganhos econômicos e ambientais, estes relativos à qualidade do ar. Também sabemos que, mesmo com uma pequena participação da hidreletricidade em sua matriz energética, a Tchecoslováquia entrou em conflito, em 1992, com a Hungria para garantir o suprimento dessa fonte energética. Portanto, em situações específicas, a baixa participação da hidreletricidade combinada com novas demandas energéticas também pode representar um indicador de vulnerabilidade.

Em síntese, encontramos na bacia do rio Danúbio um diagnóstico muito diversificado das variáveis territoriais, reflexo das grandes diferenças naturais, sociais e econômicas existentes no extenso território da bacia. Em todos os 
indicadores identificados por Gleick, encontramos as mais distintas situações desde as mais preocupantes até as mais confortáveis. $O$ indicador que apresenta um cenário mais preocupante é o da dependência hídrica externa, já que, mais da metade dos países da bacia apresentam índices elevados.

Da mesma forma, em relação aos protagonistas dos principais eventos conflitivos - Eslováquia e Hungria - o único indicador que se mostrou preocupante foi aquele relacionado a provisão dos recursos hídricos oriunda de fora das fronteiras nacionais, já que ambos os países apresentam uma dependência hídrica externa considerada muito alta.

Para completar nossa análise, apresentaremos uma avaliação das variáveis políticas ligadas as interações interestatais referentes às ATS da bacia do rio Danúbio.

\subsection{As variáveis políticas}

Definimos como variáveis políticas aquelas relacionadas ao contexto geopolítico e a "capacidade institucional" dentro de uma BHT. Também demonstramos que os resultados dos estudos BAR/TFDD sugerem que tais variáveis são tão, ou mais, importantes quanto os demais indicadores de potencial conflitivo.

O objetivo dessa seção é ponderar a validade dessa proposição utilizando como estudo de caso os principais eventos conflitivos na bacia do rio Danúbio. Em outras palavras, analisaremos as variáveis políticas envolvidas naquelas disputas entre Eslováquia e Hungria.

Recuperar o contexto geopolítico nos evidenciará o cenário das relações internacionais na escala regional e suas implicações nas relações diplomáticas entre os dois principais protagonistas. Ainda segundo os estudos BAR/TFDD, as relações internacionais (positivas ou negativas) referentes a outros temas teriam grande repercussão na questão do compartilhamento das ATS. 
Avaliar a "capacidade institucional" significa analisar a existência e eficácia de mecanismos e iniciativas supranacionais de gerenciamento conjunto das águas transfronteiriças dentro da bacia, incluindo Tratados internacionais sobre o tema.

\subsubsection{O contexto geopolítico}

A bacia do rio Danúbio corresponde a uma das áreas mais afetadas pelas transformações políticas que se verificaram na Europa ao longo do século passado.

Os postulados do geógrafo Halford Mackinder ${ }^{44}$ apresentam extrema pertinência na interpretação dos interesses geopolíticos incidentes na bacia do rio Danúbio, durante o século XX. Afinal, a região do baixo Danúbio integrava o Heartland em sua extremidade ocidental, enquanto os demais trechos da bacia se encontravam na porção oeste de um grande arco marginal que o envolvia o "Coração Continental" do mundo, denominado de Inner Crescent (MELLO, 1999).

Leonel Mello (1999) explica a função geoestratégica do Inner Crescent, segundo o arcabouço teórico mackinderiano:

Esse Crescente Interno era composto por um conjunto de zonas amortizadoras que constituíam pontos de fricção ou áreas de disputa onde se chocavam o poder terrestre e o poder marítimo. Por um lado, o Inner Crescent era o espaço natural de expansão do poder terrestre que, de posse do núcleo basilar eurasiano, procurava conquistar as regiões periféricas e obter saídas para o oceano, tendo em vista a construção de um poder marítimo. Por outro lado, o Crescente Interno era também a barreira física de contenção ou primeira linha de defesa do poder marítimo, que

\footnotetext{
${ }^{44}$ Halford Mackinder (1861-1947), geógrafo britânico, foi o formulador da teoria do poder terrestre. Seus postulados defendiam que o Heartland (que pode ser entendido como coração continental ou área pivot) do mundo situava-se na Eurásia, notadamente na região compreendida entre a Sibéria e os arredores do Mar Negro. Em seu entendimento, a potência continental que controlasse essa área seria hegemônica em relação às potências marítimas. Sua tese, afirmava "que o poder terrestre poderia conquistar as bases do poder marítimo, caso conseguisse adicionar à sua retaguarda continental uma frente oceânica que lhe possibilitasse tornar-se um poder anfíbio"(MELLO, 1999:39).
} 
procurava conter a expansão do poder terrestre e mantê-lo encurralado no coração da Eurásia (MELLO, 1999:47).

Como desdobramento dessa concepção, Mackinder (1904) afirmou: "Quem domina a Europa Oriental controla o Heartland; quem domina o Heartland controla a World Island ${ }^{45}$; quem domina a World Island controla o mundo" (Mackinder, 1904, apud Mello, 1999:56).

A relevância estratégica da Europa Oriental para a geopolítica continental e global permite-nos compreender a intensidade das disputas e das mudanças fronteiriças na bacia do rio Danúbio.

Até pouco antes da Primeira Guerra Mundial, grande parte da área da bacia estava sob o domínio de quatro impérios: o alemão, o austro-húngaro, o otomano e o russo.

O fim do conflito trouxe a primeira grande modificação na estrutura geopolítica da área, à medida que os impérios que exerciam o domínio sobre ela se desintegraram, dando origem a uma série de novos Estados, como foram os casos da Hungria, da Áustria, da antiga Tchecoslováquia e do Reino dos Sérvios, Croatas e Eslovenos (lugoslávia).

Nesse processo idéias de Mackinder tiveram influência direta. Mello (1999) relata que o geógrafo, na condição de assessor da diplomacia britânica, propôs a criação de uma cadeia de Estados-tampões na Europa Oriental com o intuito de isolar a Alemanha derrotada da Rússia bolchevique. De um total de sete países que formavam esse "cordão sanitário", seis eram integrantes da bacia do rio Danúbio: Polônia, Tchecoslováquia, Hungria, lugoslávia, Bulgária e Romênia (MELLO, 1999:57).

A segunda grande transformação foi mais efêmera e correspondeu ao domínio nazista sobre toda a região durante grande parte da Segunda Guerra Mundial. Com a derrota nazista, amplas áreas da bacia do Danúbio, que haviam sido libertadas pelo exército da União das Repúblicas Socialistas Soviéticas (URSS),

\footnotetext{
${ }^{45}$ Para Mackinder, o World Island era um único grande continente formado pelas massas terrestres da África, Europa e Ásia.
} 
passaram a integrar o chamado bloco soviético. Essa importante transformação ao fim da Segunda Guerra manteve o status político da região inalterado por mais de quatro décadas. Período em que a superpotência continental manteve o controle geopolítico e uma relativa estabilidade na Europa Oriental.

A última grande mudança ocorreu no final da década de 1980, quando do fim dos regimes socialistas na região, fato que levou à desintegração de alguns Estados danubianos como a lugoslávia, Tchecoslováquia e URSS. A antiga lugoslávia deu origem a cinco novos países, sendo que, com exceção da Macedônia, todos têm terras na bacia do Danúbio. A antiga Tchecoslováquia deu origem a dois novos Estados danubianos: República Theca e República da Eslováquia. O desmembramento do Estado soviético criou quinze novas repúblicas, sendo que duas possuem territórios nessa bacia: Ucrânia e Moldávia.

Nos vários conflitos que ocorreram na região durante o século $X X$, um elemento sempre esteve presente em maior ou menor grau: a existência de minorias étnico-nacionais que, muitas vezes, funcionaram como estopim de confrontos entre Estados e no interior deles.

Ainda hoje o problema das minorias tem persistido. Dentre eles podem ser destacados os que ocorreram no território da antiga lugoslávia: na Croácia, na Bósnia, no Kosovo e na Macedônia; os que envolveram o governo da Bulgária e a minoria de origem turca que habita o país, além daqueles representados pela presença de minorias húngaras na Sérvia (região da Voivódina), no sul da Eslováquia e principalmente no interior da Romênia (região da Transilvânia).

Da mesma forma que o fim do domínio soviético na região foi um dos fatores para o recrudescimento de conflitos étnicos, entendemos que esse foi o principal responsável pela intensificação, após 1989, de eventos conflitivos relacionados às ATS na bacia do rio Danúbio, conforme ilustrado pelo GRÁFICO 4.4. Considerando que divergências geram demandas por soluções, dialeticamente, essa concentração de casos conflitivos trouxe um aumento das interações neutras e cooperativas.

Quanto à Hungria e a então Tchecoslováquia, acreditamos que quatro variantes do contexto geopolítico incidiram - em graus diferenciados - nas relações bilaterais relativas ao caso Gabcikovo-Nagymaros: a influência da URSS, a crise do 
socialismo real, a questão das minorias étnicas e processo de ampliação da então CEE.

Após a segunda guerra mundial o controle geopolítico da URSS sobre o Leste Europeu - incluindo a existência do Pacto de Varsóvia (1955-1989) - foi vital para estabilidade política entre os vizinhos. Em virtude disso, antigos nacionalismos e reivindicações territoriais tchecas sobre terras húngaras, banhadas pelo Danúbio, foram abafadas (VILLIERS, 2002: 245).

Além disso, a região sempre despertou grande interesse geoestratégico e econômico para Moscou, visto que grandes quantidades de cargas soviéticas eram escoadas pelo rio Danúbio. Na década de 1950, a URSS estimulou a construção de obras para melhorar a navegação entre o trecho Gyor-Bratislava e integrar o rio ao canal Danúbio-Meno-Reno ${ }^{46}$. Afinal esse canal representaria uma das escassas possibilidades de interligação fluvial entre o Heartland e o Midland Ocean ${ }^{47}$, para retomarmos as formulações mackinderianas,

Até década de 1970, tais obras não haviam sido concluídas como o previsto, porém, o interesse e a influência dos soviéticos foram decisivos na negociação e elaboração do Tratado referente ao sistema Gabcikovo-Nagymaros, firmado em 1977(VILLIERS, 2002: 245).

Já as divergências entre o governo da Hungria e da Tchecoslováquia têm que ser analisadas em um contexto de colapso do socialismo real, ocorrido a partir da segunda metade da década de 1980. Por um lado, acompanhamos, um drástico enfraquecimento da autoridade soviética, processo que culminou com o fim do regime socialista nos países do Leste Europeu e a dissolução do Pacto de Varsóvia.

Por outro lado, esse colapso foi acompanhado por uma grave uma crise econômica que atingiu, em graus diferenciados, todos os países do bloco soviético. Como vimos, problemas de ordem financeira estiveram entre os motivos da desistência húngara.

\footnotetext{
${ }^{46}$ Uma das seções críticas desta via fluvial situa-se entre Bratislava e Budapeste.Trata-se de um trecho plano à jusante de terrenos montanhosos, essa mudança súbita na geomorfologia causa sedimentação excessiva formando um delta interior, denominado Szentendre Island (vide mapa 4.2). Sem nenhuma intervenção para mitigação desses efeitos essa seção não pode ser utilizada para navegação em larga escala.

${ }^{47} \mathrm{O}$ conceito de Midland Ocean foi apresentado por Mackinder em 1943 e correspondia, em termos descritivos, à toda a bacia do Atlântico Norte (MELLO,1999:65).
} 
A proteção da minoria magyar que vive no território vizinho - cerca de $10 \%$ da população da Eslováquia - também esteve entre as preocupações do governo húngaro na ocasião da construção da "variante C". Afinal, com o desvio do rio, os eslovacos poderiam utilizar a ameaça de seu fechamento - e conseqüente estrangulamento do comércio externo húngaro - como forma de pressão, contra revoltas separatistas, que seriam, potencialmente, incentivadas por Budapeste (VILLIERS, 2002: 246).

Também vimos que, a CEE (atual União Européia) teve um papel decisivo na mediação do conflito em seu momento mais agudo, outubro de 1992; quando desdobramentos violentos ainda não estavam descartados. Esse fato reflete tanto a redução da influência soviética quanto o aumento da influência da CEE na região. $\mathrm{Na}$ ocasião, ambos os países envolvidos no litígio já demonstravam pretensões de aderir à CEE e, portanto, deveriam se mostrar capazes de resolver suas disputas à "maneira européia". Por sua vez, os europeus ocidentais, já alarmados com a questão dos Bálcãs e do Chipre, não queriam ver eclodir um novo conflito violento em suas adjacências. Ademais, como explicariam uma guerra pela água em pleno "coração do mundo civilizado"?

Entendemos que, as circunstâncias expostas nessa seção influenciaram diretamente as interações referentes às ATS na bacia do rio Danúbio e demonstram a coerência dos resultados dos estudos BAR/TFDD, que apontam uma concentração espacial e temporal de eventos conflitivos na bacia. Assim concluímos que, as variáveis políticas relacionadas ao contexto geopolítico apresentam fortes relações com os conflitos na Bacia do Danúbio, em especial no caso Gabcikovo-Nagymaros.

\subsubsection{As iniciativas de gerenciamento conjunto}

O gerenciamento conjunto do rio Danúbio possui cerca de 150 anos de tradição. O Tratado de Paris, de 1856, lançou as raízes da Comissão Européia para o Danúbio (CED) que é composta por representantes de cada um dos países que se localizam 
ao longo do rio. Até a Segunda Guerra Mundial a CED ficou responsável pela administração do Rio Danúbio, suas demandas iniciais estavam relacionadas à navegação e a Comissão conseguiu estabelecer a navegação livre ao longo do rio para todos os países europeus.

A Segunda Guerra alterou o cenário geopolítico, implicando em novas alianças entre o Estados ribeirinhos e a uma nova concepção de gerenciamento. Em 1948, na Conferência de Belgrado, os países do Bloco Oriental revogaram as regras de navegação vigentes e adotaram o controle exclusivo de cada país ribeirinho. Ainda de acordo com a Convenção de Belgrado, a Comissão passa a ter poderes semi-legislativos relativos à navegação e inspeção.

Mesmo tendo como principal tarefa assegurar as condições de navegação ao longo do rio, a CED também desenvolveu planos regionais para projetos fluviais, disseminou propostas dos países ribeirinhos, além de criar sistemas reguladores e de coleta de dados. A Comissão se reúne anualmente ou em sessão especial e, embora a maioria dos votos seja suficiente para aprovar uma proposta, na prática é solicitada a unanimidade. A CED não tem nenhum poder soberano e suas decisões são consideradas recomendações aos governos de seus membros.

Em meados da década de 1980, estava claro que, outras questões passaram a ter relevância além da navegação, principalmente aquelas ligadas à qualidade das águas. Como sabemos ao longo de seu trajeto o rio recebe efluxos de milhões de indivíduos, da agricultura e da indústria. Além disso, o colapso da URSS também contribuiu aumentar a deterioração das águas da bacia, visto que as economias nascentes possuíam poucos recursos para o combate a tais problemas. Reconhecendo a crescente degradação da qualidade das águas, oitos Estados ribeirinhos assinaram a Declaração dos Países do Danúbio para Cooperar em Questões Relativas à Administração de Água do Danúbio, conhecida como Declaração de Bucareste, de 1985.

A Declaração de Bucareste reforçou o preceito de que a qualidade ambiental do rio depende das condições ambientais da bacia como um todo e formalizou o compromisso dos Estados ribeirinhos em adotar uma abordagem regional e integrada para o gerenciamento da bacia hidrográfica. 
Entre os desdobramentos iniciais foi estabelecida uma rede de monitoramento ao longo da bacia. A coordenação da área foi estreitada em reuniões em Sofia, em Setembro de 1991, nas quais foi elaborado um plano para a restauração e proteção da qualidade da água do rio Danúbio. Com essa iniciativa, denominada Programa para o Meio ambiente para a área do Rio Danúbio, os participantes concordaram que cada um dos países ribeirinhos deveria:

- atacar o tema da poluição interfronteiras;

- definir regras para a proteção do habitat das terras alagadas;

- definir um guia para o desenvolvimento de maneira que as áreas de importância ecológica ou de valor estético sejam conservadas.

O evento de Sófia também criou uma força-tarefa interina para coordenar o cumprimento das metas, enquanto uma Convenção para guiar o Programa estava sendo negociada.

A regulamentação das ATS da bacia do rio Danúbio é feita através de uma grande quantidade de acordos internacionais. O Atlas of International Freshwater Agreements - publicado pelo Programa das Nações Unidas para o Meio Ambiente, em 2002 - registra um conjunto 42 Tratados de escopo bilateral e multilateral, firmados por Estados integrantes dessa bacia (UNEP, 2002:79 - 83). Dentre eles, 0 mais abrangente e ambicioso é a Convenção para Proteção e Sustentabilidade das Águas do Rio Danúbio (Convenção de Proteção do Rio Danúbio).

Em 29 de junho de 1994, na cidade de Sófia, onze países ${ }^{48}$ integrantes da bacia do Danúbio e a União Européia assinaram uma Convenção que oferece disposições legais destinadas a alcançar um gerenciamento integrado, sustentável e eqüitativo das águas da bacia. Este episódio concluiu os trabalhos, conduzidos pela Áustria, iniciados em fevereiro de 1991 quando os países envolvidos decidiram criar um documento dessa natureza.

A Convenção para Proteção do Danúbio foi elaborada tendo como referência a Convenção de Helsinque. Considerando que esse acordo, firmado em 1992, é considerado um umbrella treaty, suas principais diretrizes e proposições são

48 Áustria, Bulgária, Croácia, República Tcheca, Alemanha, Hungria, Moldávia, Romênia, Eslováquia, Eslovênia, Ucrânia. 
reafirmadas na Convenção de 1994. Incluindo os princípios de poluidor-pagador e o princípio da precaução.

Os princípios e objetivos essenciais a serem seguidos pelos Estados danubianos ${ }^{49}$ são explicitados no artigo $2^{\circ}$ da Convenção.

Artigo 20: "(1) The Contracting Parties shall strive at achieving the goals of a sustainable and equitable water management, including the conservation, improvement and the rational use of surface waters and ground water in the catchment area as far as possible. Moreover the Contracting Parties shall make all efforts to control the hazards originating from accidents involving substances hazardous to water, floods and icehazards of the Danube River. Moreover they shall endeavour to contribute to reducing the pollution loads of the Black Sea from sources in the catchment area.

(2) The Contracting Parties pursuant to the provisions of this Convention shall cooperate on fundamental water management issues and take all appropriate legal, administrative and technical measures, to at least maintain and improve the current environmental and water quality conditions of the Danube River and of the waters in its catchment area and to prevent and reduce as far as possible adverse impacts and changes occurring or likely to be caused.

(3) To this end the Contracting Parties, taking into account the urgency of water pollution abatement measures and of rational, sustainable water use, shall set priorities as appropriate and shall strengthen, harmonise and coordinate measures taken and planned to be taken at the domestic and international level throughout the Danube Basin aiming at sustainable development and environmental protection of the Danube River. (...)

\footnotetext{
49 A Convenção de Proteção do Danúbio define no parágrafo "A" do artigo 1 "Estados soberanos que compartilhem uma parte considerável da área de contribuição hidrológica do rio Danúbio. Como parte considerável fica assumido um compartilhamento excedente a $2.000 \mathrm{~km}^{2}$ da área de contribuição hidrológica do rio.
} 
(4) The Polluter pays principle and the Precautionary principle constitute a basis for all measures aiming at the protection of the Danube River and of the waters within its catchment area. Convenção para Proteção do Danúbio. Disponível em $<w w w . i c p d r . o r g>$. Acesso 14 fev 2005.

A análise destas proposições, combinada com a definição de impactos transfronteiriços ${ }^{50}$, permite-nos concluir que, esse documento focaliza a questão da qualidade das águas transfronteiriças e omite-se em questões de quantidade, assim como a Convenção de Helsinque. Está explicitado no $2^{\circ}$ parágrafo do artigo transcrito, que o polêmico princípio do uso eqüitativo ficou limitado à dimensão da sustentabilidade ambiental. Além disso, a também polêmica obrigação de não causar dano significativo, um dos principais pontos de discórdia da CCAI, não aparece no texto.

De forma análoga à nossa avaliação sobre a Convenção de Helsinque, apresentada no capítulo anterior, entendemos que o fato da Convenção de Proteção do Danúbio não abordar diretamente a questão da soberania e do compartilhamento das águas transfronteiriças sob seu aspecto quantitativo foi fundamental para a ampla aceitação do documento e sua rápida entrada em vigor, que ocorreu em maio de 1998.

De qualquer forma, a Convenção de Proteção do Danúbio representa o mais amplo Tratado internacional referente às águas transfronteiriças daquele rio e oferece um complexo "framework" para gerenciamento integrado do uso da água e para a proteção ao meio ambiente numa área de grande potencial conflitivo.

Porém, em que pese seu caráter de indutor de cooperação internacional, a Convenção de Proteção do Danúbio ainda não se fez refletir de forma contundente nos registros BAR/TFDD. Nossas pesquisas sobre tais apontamentos demonstraram

\footnotetext{
50 A Convenção de Proteção do Danúbio define no parágrafo "C" do artigo $1^{\circ}$.: "Transboundary impact" means any significant adverse effect on the riverine environment resulting from a change in the conditions of waters caused by human activity and stretching out beyond an area under the jurisdiction of a Contracting Party. Such changes may affect life and property, safety of facilities and the aquatic ecosystems concerned.
} 
que nenhum dos eventos cooperativos ocorridos após a sua assinatura (junho de 1994) possui relação direta com os desdobramentos da Convenção. Por outro lado, conforme ilustrado GRÁFICO 4.4, sua existência não foi capaz de conter os eventos conflitivos na bacia.

Em relação às desavenças entre a Hungria e Eslováquia, referentes ao caso Gabcikovo-Nagymaros, esta iniciativa não apresenta nenhuma relação. Apesar de ambos protagonistas serem Partes da Convenção de Proteção do Danúbio e isso potencialmente proporcionar um relacionamento bilateral positivo, a assinatura e entrada em vigor do acordo não foi acompanhada da interrupção dos eventos conflitivos entre eles, conforme demonstrado no GRÁFICO 4.6. Por outro lado, nossas pesquisas evidenciaram que os eventos cooperativos também não foram realizados sob os auspícios da Convenção.

Portanto, nesse caso específico, a existência de um acordo sobre o tema também não foi suficiente para evitar o conflito. Pelo contrário, como vimos, as divergências se agravaram quando Hungria anunciou o rompimento do Tratado de 1977.

Assim, concluímos que, a capacidade institucional dentro da bacia do Danúbio, apesar de apresentar instrumentos bem evoluídos, como a Convenção de 1994, não apresenta fortes relações com os eventos conflitivos registrados.

\subsection{0 caso húngaro - eslovaco: um paradigma}

A avaliação do caso Gabcikovo-Nagymaros, que envolveu Hungria e Eslováquia, permite-nos chegar a importantes constatações sobre de ATS.

Sua ocorrência comprova que o potencial conflitivo envolvido na questão pode, em um curto espaço de tempo, se transformar em fonte de conflito efetivo. Como vimos, as disputas pelas águas transfronteiriças do rio Danúbio exerceram um forte papel na deterioração das relações internacionais entre Hungria e a então 
Tchecoslováquia. Conforme demonstramos, as posturas unilaterais de ambas as partes trouxe a possibilidade da eclosão de um conflito violento.

Ademais, esse caso comprova que o realismo político continua presente nas relações internacionais contemporâneas, sobretudo naquelas que envolvem a partilha de recursos naturais imprescindíveis, como é o caso das ATS. Essa constatação reafirma as conclusões de Ribeiro (2001 e 2004).

Por outro lado, o desfecho não violento do caso Gabcikovo-Nagymaros reflete outra tendência da questão: na atualidade ainda são raros os casos em que disputas pelas águas transfronteiriças são resolvidas pela dissuasão e coerção militar. Essa propensão já havia sido apontada pelos resultados dos estudos BAR/TFDD, apresentados no capítulo anterior.

Nosso diagnóstico, referente ao potencial conflitivo, constatou que não é necessária a sobreposição de muitos daqueles indicadores apontados pela bibliografia especializada para que o conflito se efetive. Em nosso estudo de caso bastou a combinação de dois deles para surgimento das controvérsias: um indicador relacionado às variáveis territoriais e outro relacionado às variáveis políticas.

Quanto às variáveis territoriais analisadas, somente a dependência hídrica externa mostrou forte relação com o conflito, visto que, tanto Hungria quanto Eslováquia apresentam uma dependência considerada extremamente alta. Nas demais variáveis territoriais - estresse hídrico, disponibilidade hídrica e dependência de energia hidrelétrica - ambos os países encontram-se em situação confortável, segundo critérios indicados por Gleick (1994).

Também ficou comprovada a centralidade do fator: posição geográfica. Afinal, a dependência hídrica externa "extremamente alta" nos dois Estados protagonistas deve-se ao fato deles estarem no médio curso do rio e por apresentarem seus territórios quase integralmente inseridos na bacia ${ }^{51}$. Além disso, a evolução da questão evidenciou a vantagem proporcionada pela posição geográfica da Eslováquia - à montante do rio - já que esta Ihe viabilizou a possibilidade de desviar o curso d'água para seu território, com a construção da "variante C".

\footnotetext{
${ }^{51}$ A Hungria está 100\% inserida, enquanto a Eslováquia possui 95\% de seu território na bacia do rio Danúbio.
} 
Quanto às variáveis políticas analisadas, as mudanças no cenário geopolítico mostraram forte relação com o conflito. Como vimos, as divergências se desencadearam em um contexto de colapso do socialismo real, que acarretou drásticas mudanças de circunstâncias, tais como: uma crise econômica, o enfraquecimento da autoridade soviética e uma maior participação da sociedade civil em decisões do Estado húngaro.

Os pesquisadores do projeto BAR/TFDD (YOFFE; WOLF; GIORDANO, 2003) também demonstram pertinência ao identificar as mudanças rápidas ou extremas como um importante fator de conflito. Na questão analisada, a Hungria provocou uma brusca mudança no cenário institucional ao suspender e depois revogar o Tratado de 1977, desencadeando uma série de eventos conflitivos. De outro lado, a iniciativa da Tchecoslováquia de construir a "variante C" representou uma mudança extrema no cenário físico, fato que intensificou o grau conflitivo.

Por outro lado, a capacidade institucional de gerenciamento conjunto não se mostrou capaz de evitar o conflito. Como vimos, nem a CED nem outros mecanismos institucionais, criados a partir de 1991, apresentaram-se na mediação do conflito. Tampouco a existência de um Tratado internacional sobre o tema foi capaz se evitar o conflito.

O caso também ilustra que a dimensão ambiental tornou-se uma importante variável no compartilhamento das ATS. Como vimos, preocupações dessa natureza originaram amplas manifestações populares na Hungria, além de ter sido principal motivo declarado pelo governo daquele país para a revogação do Tratado de 1977. Entre os argumentos húngaros apresentados ao Tribunal de Haia estava: "o desenvolvimento de novas normas e leis internacionais sobre meio ambiente" (ICJ, 1997). Tais fatos confirmam que alguns elementos da teoria da interdependência têm que ser incorporados na interpretação dos subsistemas da OAI, em especial a participação de atores não estatais como as ONGs ambientalistas.

Em nosso entendimento, a intervenção ClJ contribuiu para tornar o caso Gabcikovo-Nagymaros em um paradigma nos estudos sobre as iniciativas de compartilhamento das ATS. Desta forma, esse episódio passou a representar um importante marco nesse subsistema em construção da OAl. 
O fato de a questão ter se transformado na primeira demanda ambiental arbitrada pelo Tribunal de Haia já aponta o valor estratégico dos recursos hídricos no mundo contemporâneo. Afinal, qual o recurso natural inauguraria a temática ambiental nessa esfera jurídica, senão aquele mais essencial à vida e, conseqüentemente, aos Estados?

Além disso, a eminência desse tribunal e o ineditismo dessa demanda conferem ao caso grande relevância na jurisprudência sobre o assunto. Por isso entendemos que, as decisões do Tribunal de Haia, apesar de não estarem isentas de polêmicas, oferecem pistas de como o direito internacional tende a interpretar as polêmicas envolvidas nas disputas pelo compartilhamento das ATS.

Entre as decisões da ClJ, entendemos que duas questões merecem destaque: o entendimento sobre soberania e a influência do princípio da sustentabilidade ambiental.

A decisão de que a então Tchecoslováquia não tinha o direito de colocar a "solução provisória" em operação, ou seja, proceder ao desvio das águas do Danúbio, revela que a Corte rechaçou a doutrina da soberania territorial absoluta. Por outro lado, ao exigir que ambas as Partes negociassem uma solução eqüitativa e ambientalmente válida, o Tribunal deixa subentendido que o desfecho de disputas por ATS deve ser realizado sob a concepção da soberania territorial limitada e integrada.

A análise do veredicto da Corte, e das posturas das Partes após tais decisões, comprovam que as preocupações com a sustentabilidade ambiental passam a incorporar, de forma definitiva, as decisões sobre o compartilhamento das ATS, tornando a questão sensivelmente mais complexa. Ao avaliar o caso Gabcikovo-Nagymaros, Fuyane e Madai concluem:

It is noteworthy however that subsequent negotiations between the parties have been in keeping with sustainable development. The parties are demonstrating the importance of a concept, which was treated only as orbiter by the Court. Their negotiations reveal that the issues relevant to their dispute are of an environmental nature (FUYANE e MADAI, 2001:340). 
Em função disso, concluímos que indicadores capazes de diagnosticar as variáveis ambientais envolvidas na questão do compartilhamento das ATS devem ser incorporados aos indicadores de potencial conflitivo já consagrados pela literatura especializada. Tais indicadores ambientais precisam avaliar os prováveis impactos e a relação entre perdas e ganhos ambientais para os Estados envolvidos. Como vimos na postura da Hungria frente ao Projeto Gabcikovo-Nagymaros, além das variáveis territoriais e das variáveis políticas, a questão da sustentabilidade tornou-se mais um elemento ponderado na tomada de decisões estatais. 


\section{5 - Considerações Finais}

Os dados analisados no início de nosso trabalho demonstram que atualmente não são poucas as regiões do globo que já sofrem com a escassez de água. O mais preocupante é que se prevê um acirramento dessa crise para o médio e curto prazo. Uma das implicações desse fato manifesta-se no aumento do potencial conflitivo relativo ao compartilhamento das águas transfronteiriças superficiais (ATS).

Demonstramos que as ATS representam a maior parcela da água doce superficial do Globo, sendo que 145 países possuem seus territórios inseridos em bacias hidrográficas transfronteiriças (BHT). Fatos que evidenciam a importância desses recursos para a vida e para os Estados. Na avaliação dos desafios que circundam a questão das ATS, ressaltamos que os de maior complexidade são inerentes às circunstâncias geográficas e políticas das BHT. Afinal, raramente os limites físicos desses sistemas hidrográficos coincidem com os limites políticos dos Estados nacionais.

Um dos desafios está relacionado à capacidade das disputas pela partilha das ATS ameaçarem a segurança ambiental internacional. A partir da bibliografia especializada, identificamos os fatores envolvidos na questão e defendemos que eles podem ser sintetizados em: variáveis territoriais e variáveis políticas. Enquanto estas estão ligadas ao contexto geopolítico e a "capacidade institucional" dentro da $\mathrm{BHT}$, aquelas referem-se aos indicadores ligados aos estoques e demandas hídricas, que são determinados por fatores naturais, econômicos e sociais, que se materializam fisicamente no território.

Outro desafio refere-se às supostas limitações à concepção de soberania, impostas pelo caráter transnacional das questões ambientais e, em especial, das ATS. Como vimos, a dinâmica natural das BHT faz com que a soberania territorial de cada Estado seja influenciada por fatores externos. Concluímos, então, que os Estados que tomam decisões cooperativas frente às concorrências próprias às ATS aceitam a concepção de soberania compartilhada. 
Porém, esclarecemos: essa constatação não advoga o abandono do conceito de soberania e sim a necessidade de redefinição de sua concepção clássica (soberania absoluta). Acreditamos na relevância desse conceito nos dias de hoje, inclusive frente aos desafios que envolvem o compartilhamento das ATS. Isso porque, em primeiro lugar, o sistema internacional é fundamentado na unidade dialética entre a face externa e interna da soberania, os Estados soberanos só têm seus direitos garantidos porque assumem determinadas obrigações. Em segundo lugar, estamos convencidos de que a adesão a um Tratado internacional não fere o princípio da soberania, desde que ele tenha sido firmado em condições de equidade entre as Partes.

Também queremos enfatizar que qualquer afirmação sobre a flexibilização do atual valor da noção de soberania deve ser feita com cautela e a partir de uma devida contextualização. Isso para evitar generalizações que podem ser utilizadas na repercussão de um pensamento único, que não é isento de interesses. Em tempos de ideologias liberais e globalizantes, muitos são os arautos da caducidade da soberania nacional, do fim das fronteiras e da morte do Estado. Nesse sentido, atentamos para a recomendação do ilustre geógrafo Milton Santos (2000):

De que maneira a globalização afeta a soberania das nações, as fronteiras dos países e a governabilidade é uma questão que volta e meia ocupa os espíritos, seja teoricamente, seja em função de fatos concretos. Neste terreno, como em muitos outros, a produção de meias-verdades é infinita e somos freqüentemente convocados a repeti-las sem análise do problema (SANTOS, 2000:76).

Analisamos as iniciativas de regulamentação do compartilhamento das ATS como um subsistema específico da ordem ambiental internacional (OAI) que está em evolução. Diferente de subsistemas que já possuem uma Convenção de âmbito global, no caso das ATS a regulamentação é realizada na escala regional (subcontinental). Entendemos que tais singularidades possuem fatores políticos e geográficos. Por um lado o realismo político e salvaguarda da soberania não permitiu que uma Convenção mundial entrasse em vigor. Por outro, os limites e a 
dinâmica das BHT tornam a escala subcontinental - delimitada pelas BHT - a mais adequada para a defesa dos interesses nacionais.

Se a falta de regulamentação de escopo mundial denuncia a prevalência do realismo político nessa escala de análise, os inúmeros acordos bilaterais e multilaterais demonstram que a teoria da interdependência também possui valor explicativo no subsistema das ATS, confirmando os postulados de Ribeiro (2001), que ressaltam a necessidade de combinarmos ambas as teorias, para apreendermos a complexidade da OAI.

O estudo realizado sobre a bacia do rio Danúbio nos permitiu avaliar em um caso concreto muitas das questões levantadas anteriormente. Em primeiro lugar, o balanço dos eventos conflitivos apresentou uma clara concentração, tanto espacial quanto temporal, já que a grande maioria dos conflitos referente ao compartilhamento das ATS, aconteceu entre Hungria e Eslováquia, no pós guerra fria. Episódios suficientes para não deixar dúvida: o potencial conflitivo envolvido na questão pode, em um curto espaço de tempo, se transformar em fonte de conflito efetivo.

Quanto aos indicadores envolvidos constatamos que não é necessária a sobreposição de muitos deles para a eclosão de um cenário conflitivo, nesse caso bastou a combinação de uma variável territorial - a dependência hídrica externa - e uma variável política - o contexto geopolítico - para o desencadeamento dos conflitos. A partir desse caso, identificamos a necessidade de ser avaliada a questão da sustentabilidade e sugerimos que nos trabalhos referentes à identificação de potencial conflitivo também seja ponderada uma "variável ambiental". Desde já, nos propomos à tarefa de criar, em trabalhos futuros, subsídios para a elaboração dessa variável. 
Referências bibliográficas

ALBUQUERQUE, Newton M. Teoria da soberania. Belo Horizonte: Mandamentos, 2001.

ANDRADE, Manuel Correia. O desafio ecológico: utopia e realidade. São Paulo: Hucitec, 1994.

ARON, Raymond. Paz e guerra entre as nações. Brasília: Ed UnB/ IPRI, São Paulo: IOESP, 2002.

BARTELSON, Jens. A genealogy of sovereignty. New York: Cambridge University Press, 1995.

BECKER, Bertha K. A geografia e o resgate da geopolítica. Revista Brasileira de Geografia. Rio de Janeiro. № especial. p. 99-125, 1988.

BID - Banco Interamericano de Desarrollo. Estratégia para el manejo intergrado de los recursos hidricos. Washington D.C.: BID, 1998.

BOBBIO, Norberto; METTEUCCI, Nicola; PASQUINO, Gianfranco. Dicionário de Politica. 5a. Ed. São Paulo: Ed UnB, 2004. 2v.

BODIN, Jean. Los seis libros de la República. 2ªed. Madrid:Tecnos, 1992.

CANO, Javier Sanches. De la seguridad compartida a la seguridad ecológica. Revista Ecologia Política. Barcelona, vol 15, p. 11-30, 1998.

CAVALCANTI, Clóvis (Org.) Desenvolvimento e natureza: estudos para uma sociedade sustentável. São Paulo: Cortez, Recife: Fundação Joaquim Nabuco, 1995.

CMMAD - Comissão Mundial sobre Meio Ambiente e Desenvolvimento. Nosso futuro comum. Rio de Janeiro: FGV, 1988.

CNUMAD - Conferência das Nações Unidas sobre Meio Ambiente e Desenvolvimento. Agenda 21. Brasília: Câmara dos Deputados, 1995.

COLUMBUS, Theodore. O estudo das relações internacionais: teoria e prática. In: Introduction to internacional relations: power and justice. New Jersey: Prentice Hall, 1986.

COSTA, Wanderley Messias. Geografia política e geopolítica: discursos sobre território e poder. São Paulo: Edusp/Hucitec, 1992. 
COSTA, Wanderley Messias. O Estado e as políticas territoriais no Brasil. 10ª ed. São Paulo: Contexto, 2001.

DABELKO, G. e DABELKO, D. Seguridad médio ambiental: cuestiones polêmicas y redefiniciones. Revista Ecologia Política. Barcelona, vol. 15, p. 31-46, 1998.

DIOP, Sali e REKACEWICZ, Philippe. Atlas mondial de l'eau: une pénurie annoncée. Paris: Éditions Autrement/PNUE/Memorial de Caen, 2003.

DUPAS, Gilberto e VIGEVANI, Tullo (Org). O Brasil e as novas dimensões da segurança internacional. São Paulo: Alfa-Omega, 1999.

ELLIOTT, Lorraine. The Global politics of the environment. Londres: Macmillan, 1998.

FERRAJOLI, Luigi. A soberania no mundo moderno: nascimento e crise do estado nacional. São Paulo: Martins Fontes, 2002.

FREDERICK, Kenneth D. Water as a source of international conflict. Ressources for the future. Washington D.C., 1996.

FUYANE, B. e MADAI, F. The Hungary-Slovakia Danube river dispute:implications for sustainable development and equitable utilizaton of natural resources in international law. Int. J. Global Environmental Issues, Vol 1(3/4), 2001. Disponível em <www.transboundarywaters.orst.edu>. Acesso em: 25 ago 2004.

GONÇALVES, Carlos W. P. Da geografia às geo-grafias: um mundo em busca de novas territorialidades. In: CECEÑA, Ana E. e SADER, Emir (Orgs). A guerra infinita: hegemonia e terror mundial. Petrópolis: Vozes / CLACSO / LPP, p.289-358, 2002.

GONÇALVES, Carlos W. P. Os descaminhos do meio ambiente. 6ª ed. São Paulo: Contexto, 1998.

GLEICK, Peter H. (org). Water in crisis: a guide to the world's fresh water resources. New York: Oxford University Press, p. 92-104, 1993.

GLEIK, Peter H. Amarga água Dulce: los conflitos por recursos hídricos. Revista Ecología Política. Barcelona, no 8. p. 85-106, 1994.

GRASA, Rafael. 1998. Las nuevas concepciones de la seguridad: el debate sobre la seguridad ecológica o seguridad ambiental. Ecología política. Barcelona, № 15. p. 7-10, 1998. 
GRASA, Rafael. Los conflictos verdes: su dimension interna e internacional. Revista Ecología Política. Barcelona, no 8. p. 25-40, 1994.

GUIMARÃES, Roberto P. A assimetria dos interesses compartilhados: América Latina e a agenda global do meio ambiente. In LEIS Héctor R. (Org.) Ecologia e política mundial. Rio de janeiro: FASE / Vozes / AIRI / PUC-Rio, p. 99-134, 1991.

HELLER, Hermann. La soberania: contribución a la teoría del derecho internacional estatal y del derecho internacional. $2^{2}$ ed. Santiago do Chile: UNAM / Fondo de Cultura Econômica do México, 1995.

HINSLEY, F. H. El concepto de soberanía. Madrid: Labor, 1972.

HOMER-DIXON, Thomas F. On the threshold: environmental changes as causes of acute conflict. In. International Security, $16(2), 1991$.

IANNI, Otávio. A sociedade Global. Rio de Janeiro: Civilização Brasileira, 1992.

IANNI, Otávio. Globalização, a grande ruptura. Revista Problemas Brasileiros, no 318, nov/dez, 1996.

ICJ - International Court of Justice. Judgment case concerning the GabcikovoNagymaros project. 25 set 1997. Disponível em <www.icj-cij.org>. Acesso em: 20 set de 2005.

ICPDR - International Commission for the Protection of the Danube River. Active for the Danube river basin, 2004. Disponível em <www.icpdr.org>. Acesso em: 15 fev 2005.

ICPDR - International Commission for the Protection of the Danube River. The Danube river Basin District: part A - basin-wide overview, 2005. Disponível em <www.icpdr.org>. Acesso em: 30 maio 2005.

ILLICH, Ivan. Energia e Equidade. In: LUDD, Ned (Org.). Apocalipse motorizado: a tirania do automóvel em um planeta poluído. São Paulo: Conrad, p.33-71, 2004.

KLARE, Michael T. Resource wars: the new landscape of global conflict. New York: Owl Books, 2002.

LACOSTE, Yves. Géopolitique de l'eau. Hérodote. Paris, nº102, p.3-18, 2001.

LEFF, Enrique. A geopolítica da Biodiversidade e o desenvolvimento sustentável: economização do mundo, racionalidade ambiental e reapropriação da natureza. In: CECEÑA, Ana E. e SADER, Emir (Orgs). A guerra infinita: hegemonia e terror mundial. Petrópolis: Vozes / CLACSO / LPP, p.253-288, 2002. 
LEFF, Enrique. Epistemologia Ambiental. São Paulo: Cortez, 2001.

LEFF, Enrique. A cultura como mediação entre processos econômicos e os processos ecológicos. In: LEFF, Enrique. Ecologia, capital e cultura: racionalidade ambiental, democracia e desenvolvimento sustentável. Blumenau: Edifurb, 2000.

LEIS Héctor R. (Org.) Ecologia e política mundial. Rio de janeiro: FASE / Vozes / AIRI / PUC-Rio, 1991.

LE PRESTRE, Philippe. Ecopolítica Internacional. São Paulo: Senac, 2000.

MACKINDER, Halfdord J. The geographical pivot of history. Geographical Journal, 23, 1904.

MARSHALL, G. In: Dicionário de Ciências Sociais, Rio de Janeiro, Ed. Fundação Getúlio Vargas, 1986.

MARTíN, André Roberto. Fronteiras e nações. 3a ed. São Paulo: Contexto, 1997.

MARTÍNEZ ALIER, Joan. Da economia ecológica ao ecologismo popular. Blumenau: Edifurb, 1998.

Mc CAFFREY, Stephen. C. Water, politics and internatonal law. In: GLEICK, Peter $H$. (org). Water in crisis: a guide to the world's fresh water resources. New York: Oxford University Press, p. 92-104, 1993.

MEA - Millennium Ecosystem Assessment. Ecosystems and human well-being: Synthesis. Washington, DC: Island Press, 2005.

MELLO, Leonel I.A. Quem tem medo da geopolítica? São Paulo: Edusp/Hucitec, 1999.

MELLO, Leonel I. A. A geopolítica do Brasil e a bacia do Prata. Manaus: Ed. Universidade do Amazonas, 1997.

MIYAMOTO, Shiguenoli. Geopolítica e poder no Brasil. Campinas: Papirus, 1995.

MIYAMOTO, Shiguenoli. A questão ambiental e as relações internacionais. IFCH / UNICAMP , no 42, 1992.

MORAES, Antonio Carlos Robert Moraes. Meio ambiente e ciências humanas. $2^{a}$ ed. São Paulo: Hucitec, 1997.

MORAES, Antonio Carlos Robert Moraes (Org). Ratzel. São Paulo: Ática, 1990. 
MORELLI, Leonardo. Grito das águas (edição revista e ampliada). Joinvile: Letra d'água, 2003.

MORGENTHAU, Hans. Politics among nations: the struggle for power and peace. New York: Alfred Knopf, 1973.

NYE, Joseph S. Jr e KEOHANE, Robert O. Transnational relations and world politics. Oxford: Harvard University Press, 1973.

NACIONES UNIDAS. Manual de tratados. Sección de tratados de la oficina de asuntos jurídicos, New York, 2001

PNUMA - Programa de las Naciones Unidas para el Medio Ambiente. Nuestro Planeta. Vol. 15 (4) 2005.Disponível em <www.ourplanet.com>. Acesso em: 15 jan 2005.

PONTING, Clive. Uma história verde do mundo. Rio de Janeiro: Civilização Brasileira, 1994.

RAFFESTIN, Claude. Por uma geografia do poder. São Paulo: Ática, 1993.

RATZEL, Friedrich. O solo, a sociedade e o Estado. Revista do Departamento de Geografia. São Paulo, № 2, p.93-101, 1983.

REBOUÇAS, Aldo C. et al. (Org.). Águas Doces no Brasil: capital ecológico, uso e conservação. São Paulo: Escrituras, 1999.

REBOUÇAS, Aldo. Uso inteligente da água. São Paulo: Escrituras, 2004.

RIBEIRO, Wagner Costa. Ecologia Política: ativismo com rigor acadêmico. Biblio 3W - Revista Bibliográfica de Geografia y Ciencias Sociales. [En línea]. Barcelona: Universidad de Barcelona, 2002, ํㅡ 364. Disponível em <http|lwww.ub.es/geocrit/b3w-364.htm>. Acesso em: 20 set 2003.

RIBEIRO, Wagner Costa. A ordem ambiental internacional. São Paulo: Contexto, 2001.

RIBEIRO, Wagner Costa.. Desenvolvimento sustentável e segurança ambiental global. Biblio 3W - Revista Bibliográfica de Geografia y Ciencias Sociales. [En línea]. Barcelona: Universidad de Barcelona, 14 de septiembre de 2001(a), oㅜ 312. Disponível em <httpllwww.ub.es/geocrit/b3w-312.htm>. Acesso em: 20 set 2002.

RIBEIRO, Wagner Costa. Geografia política da água. 2004. Tese de livre docência - Faculdade de Filosofia, Letras e Ciências Humanas, Universidade de São Paulo, São Paulo, 2004. 
SACHS, Ignach. Estratégias de transição para o século XXI: desenvolvimento e meio ambiente. São Paulo: Nobel/Fundap, 1993.

SÁNCHES, Joan-Eugeni. Geografia política. Madrid: Editorial Sintesis,1992.

SANTOS, Milton. Por uma outra globalização: do pensamento único à consciência universal. Rio de Janeiro: Record, 2000.

SANTOS, Sinval Neves. Meio ambiente e política exterior brasileira: repercussões na revista Política Externa. Biblio 3W, Revista Bibliográfica de Geografía y Ciencias Sociales, Universidad de Barcelona, Vol. VIII, no ㄴ 466, 10 de octubre de 2003. Disponível em <http://www.ub.es/geocrit/b3w-466.htm>. Acesso em: 25 maio de 2004.

SÃO PAULO (Estado). Secretaria do Estado de Meio Ambiente. Entendendo o meio ambiente - v.2 São Paulo: SMA, 1997.

SHIKLOMANOV, Igor. World Fresh Waters Resources. In: GLEICK, Peter H. (org). Water in crisis: a guide to the world's fresh water resources. New York: Oxford University Press, 1993.

SILVA, Armando Corrêa. A concepção clássica da geografia política. Revista do Departamento de Geografia. São Paulo, ㄲo3, p.103-107, 1984.

SILVA, Geraldo Eulálio do Nascimento e. Direito internacional ambiental: meioambiente, desenvolvimento sustentável e os desafios da nova ordem mundial. Rio de Janeiro: Ed. Biblioteca Estácio de Sá, 1995.

SIRONNEAU, Jacques. L'eau: novel stratégique mondial. Paris: Econômica, 1996.

SOARES, Guido Fernando Silva Soares. Curso de Direito Internacional Público. Vol.1. São Paulo: Atlas, 2002.

SOARES, Guido Fernando Silva Soares. Direito Internacional e Meio Ambiente. São Paulo: Atlas, 2001.

SOARES, Guido Fernando Silva Soares. O território nacional e os espaços internacionais no Brasil. Revista Margem. São Paulo, volume 2, pp 21-35, 1993.

UNEP - United Nations Environment Programe. Global Environment Outlook 2000: UNEP's millennium report on the environment. London: Earthscan, 1999.

UNEP - United Nations Environment Programe. Atlas of international agreements. Nairobi: UNEP, 2002. 
UNEP - United Nations Environment Programe. Global Environment Outlook 3. Nairóbi: UNEP, 2002(a).

UNESCO - United Nations Educational, Scientific and Cultural Organization. Water for people, water for life: UN World Water Development Report. Paris, 2003.

UNESCO/PHI - Organização das Nações Unidas para Educação, Ciência e Cultura / Programa Hidrológico Internacional. A inércia política agrava a crise da água: primeira avaliação sistêmica das Nações Unidas sobre os recursos hídricos mundiais, Com. Imprensa n.16, 2003.

VALLAUX, Camille. Geografia social: el solo y el Estado. Madrid: Daniel Jorro Ed, 1914.

VILLIERS, Marq de. Água. Rio de Janeiro: Ediouro, 2002.

VIANA, Gilney; SILVA Marina; DINIZ, Nilo (Orgs). O desafio da sustentabilidade: um debate sócio ambiental no Brasil. São Paulo: Fundação Perseu Abramo, 2001.

WILHELMY, Manfred. Política Internacional: enfoques y realidades. Buenos Aires: Centro Interuniversitário de Desarrollo/Grupo Editor Latino Americano, 1991.

WOLF, A F. et al. Conflict and cooperation within international river basins: the importance of institucional capacity. Departament of Geociences Oregon State University. Covallis, Oregon, $2003 . \quad$ Disponível em <www.transboundarywaters.orst.edu>. Acesso em: 25 set 2005.

WOLF, Aaron et al. International River Basins of the World. International Journal of Water International Journal of Water Resources Development, vol 15 (4), december, 1999. Disponível em <www.transboundarywaters.orst.edu>. Acesso em: 25 set 2005.

WOLF, Aaron; STAHL, Kerstin e MACOMBER, Marcia. Conflict and cooperation within international river basins: the importance of intitutional capacity. Water Resources Update, vol 125. Universities Council on Water, 2003. Disponível em $<w w w . t r a n s b o u n d a r y w a t e r s . o r s t . e d u>$. Acesso em: 25 set 2005.

YOFFE, S. e LARSON, K. Basins at risk: water event Databaase methodology. In Basins at Risk: Conflict and Cooperation over International Freshwater Resources, 2002. Disponível em <www.transboundarywaters.orst.edu $>$. Acesso em: 30 set 2005.

YOFFE, Shira; WOLF, Aaron e GIORDANO, Mark. Conflict and cooperation over international freshwater resources: indicators of basins at risk. Journal of the 
America Water Resources Association, october , 2003. Disponível em <www.transboundarywaters.orst.edu>. Acesso em: 25 maio 2005.

\section{Endereços eletrônicos}

EIA - Energy Information Administration / US Government www.eia.doe.gov

FAO - Food and Agriculture Organization / AQUASTAT 2003

ftp.fao.or./agl/aglw/aquastat/aquastat2003.xls

ICPDR - International Commission for the Protection of the Danube River www.icpdr.org

IWLP - International Water Law Project

www.internationalwaterlaw.org

Pacif Institute for Studies in Development, Environment and Security www.pacinst.org

TFDD - Transboundary Freshwater Dispute Database

www.transboundarywaters. orst.edu

UNEP - United Nations Environment Programme www.unep.org

UNESCO/WWAP - United Nations Educational, Scientific and Cultural Organization/World Water Assessment Programme www.unesco.org/water/wwap 


\section{ANEXO I}

\begin{tabular}{|c|c|}
\hline \multicolumn{2}{|r|}{ Escala BAR ( Escala de intensidade de eventos) } \\
\hline Escala BAR & Descrição do evento \\
\hline-7 & Declaração formal de guerra \\
\hline-6 & $\begin{array}{l}\text { Ações militares de grande escala } \\
\text { Uso de armas nucleares; batalhas generalizadas: aérea, navais } \\
\text { ou terrestres; invasão de território; ocupação de território; } \\
\text { bombardeio maciço de áreas civis; captura de soldados em } \\
\text { batalhas; bombardeio em grande escala de instalações militares; } \\
\text { guerra química ou biológica. }\end{array}$ \\
\hline-5 & $\begin{array}{l}\text { Ações Militares de pequena escala } \\
\text { Batalhas limitadas: aérea, marítima ou fronteiriça; atos policiais } \\
\text { fronteiriços; anexação de territórios já ocupados; tomada material } \\
\text { de país alvo; imposição de bloqueios; assassinatos de líderes de } \\
\text { país alvo; suporte material de atividades subversivas contra país } \\
\text { alvo. }\end{array}$ \\
\hline-4 & $\begin{array}{l}\text { Ações políticas / militares hostis } \\
\text { Incitação a tumultos ou rebeliões (treinamento ou financiamento } \\
\text { para rebeliões); estímulo de atividades guerrilheiras contra país } \\
\text { alvo; atos terroristas limitados e esporádicos; seqüestro ou } \\
\text { tortura de cidadãos estrangeiros ou prisioneiros de guerra; } \\
\text { cessão de refúgio à terroristas; rompimento de relações } \\
\text { diplomáticas; ataques à diplomatas ou embaixadas; } \\
\text { direcionamento de assessores militares; execução de suposta } \\
\text { espionagem; nacionalização de companhias sem compensações. }\end{array}$ \\
\hline-3 & $\begin{array}{l}\text { Ações diplomáticas / econômicas hostis } \\
\text { Crescente mobilização de tropas; boicotes, imposições de } \\
\text { sanções econômicas; dificuldades de movimento terrestre, fluvial } \\
\text { ou aéreo; embargo de produtos; recusa mútua de direitos } \\
\text { comerciais; fechamento de fronteiras e bloqueio de livre } \\
\text { comunicação; manipulação de comércio ou da moeda para } \\
\text { causar problemas econômicos; suspensão de ajuda; concessão } \\
\text { de refúgio para líderes opositores; mobilizações para } \\
\text { demonstração de hostilidades contra país alvo; convocação de } \\
\text { embaixador para consultas de emergência; recusa de vistos para } \\
\text { outras nacionalidades ou restrição de movimento no país; } \\
\text { expulsão ou detenção de cidadão ou de imprensa; espionagem } \\
\text { sobre governantes oficiais estrangeiros; rescisão de grandes } \\
\text { acordos. Construção unilateral de projetos hidráulicos contra } \\
\text { protestos de outros países; redução do fluxo para outro país; } \\
\text { revogação de acordos sobre água. }\end{array}$ \\
\hline-2 & $\begin{array}{l}\text { Hostilidade verbal forte / oficial } \\
\text { Aviso de retaliações por atos; demandas e acusações }\end{array}$ \\
\hline
\end{tabular}




\begin{tabular}{|c|c|}
\hline & $\begin{array}{l}\text { ameaçadoras; condenação forte de atos e políticas especificas; } \\
\text { denúncia de líderes, sistema ou ideologia; recusa de participação } \\
\text { em reuniões ou cúpulas; ataques de propaganda em nível forte; } \\
\text { negativa de suporte; bloqueio ou veto de políticas ou propostas } \\
\text { na ONU ou de outros organismos internacionais. Somente } \\
\text { interações oficiais. }\end{array}$ \\
\hline-1 & $\begin{array}{l}\text { Hostilidade verbal leve / não oficial } \\
\text { Objeção leve a políticas ou condutas; comunicação de } \\
\text { insatisfação através de uma terceira Parte; ausência de sucesso } \\
\text { em um acordo; recusa de nota de protesto; negativa de } \\
\text { acusações; objeção à explicação de metas, posições etc; } \\
\text { requerimento de mudança na política. Hostilidades oficiais e } \\
\text { informais, incluindo notas diplomáticas de protesto. }\end{array}$ \\
\hline 0 & $\begin{array}{l}\text { Hostilidade verbal leve / não oficial } \\
\text { Objeção leve a políticas ou condutas; comunicação de } \\
\text { insatisfação através de uma terceira Parte; ausência de sucesso } \\
\text { em um acordo; recusa de nota de protesto; negativa de } \\
\text { acusações; objeção à explicação de metas, posições etc; } \\
\text { requerimento de mudança na política. Hostilidades oficiais e } \\
\text { informais, incluindo notas diplomáticas de protesto. }\end{array}$ \\
\hline 1 & $\begin{array}{l}\text { Apoio verbal leve } \\
\text { Reunião de altos oficiais; conferências sobre problemas de } \\
\text { interesse mútuo; visita de baixos oficiais para diálogo; emissão } \\
\text { de comunicados conjuntos, nomeação de embaixadores; anúncio } \\
\text { de cessar-fogo; trocas não governamentais; propostas de } \\
\text { diálogos; apoio público não governamental de regimes; troca de } \\
\text { prisioneiros de guerra; requisição de apoio para políticas; } \\
\text { exposição ou explicação política. }\end{array}$ \\
\hline 2 & $\begin{array}{l}\text { Apoio verbal oficial } \\
\text { Apoio político oficial; aumento do grupo de diplomatas para } \\
\text { embaixadas; reafirmação de amizade; pedido de ajuda junto a } \\
\text { uma terceira Parte; desculpas por ações ou declarações } \\
\text { desfavoráveis; permissão de entrada de correspondentes de } \\
\text { imprensa; agradecimento ou pedido de ajuda; retomada de } \\
\text { relações diplomáticas rompidas ou outras relações. }\end{array}$ \\
\hline 3 & $\begin{array}{l}\text { Acordo / apoio cultural cientifico } \\
\text { Início de relações diplomáticas; estabelecimento de } \\
\text { comunicações técnicas e científicas; propostas ou ofertas de } \\
\text { auxilio econômico e militar; reconhecimento de governo; visita de } \\
\text { chefes de Estado; abertura de fronteiras; condução ou aprovação } \\
\text { de acordos; condução de acordos ou trocas culturais ou } \\
\text { acadêmicas. Acordos para estabelecer grupos de trabalhos } \\
\text { cooperativos. }\end{array}$ \\
\hline 4 & $\begin{array}{l}\text { Acordo não militar, econômico, tecnológico e industrial } \\
\text { Realização de empréstimos econômicos; concordância com } \\
\text { pactos econômicos; concessão de assistências educacional, }\end{array}$ \\
\hline
\end{tabular}




\begin{tabular}{|l|l|}
\hline & $\begin{array}{l}\text { industrial ou cultural; condução de acordos comerciais ou } \\
\text { concessão de posição nacional mais favorável; estabelecimento } \\
\text { de rede de transporte e comunicações comuns; venda de } \\
\text { suprimentos tecnológicos e industriais excedentes; provisão de } \\
\text { técnicos peritos; suspensão de restrições econômicas; fim de } \\
\text { restrições econômicas; reembolso de débitos; venda de produtos } \\
\text { não militares; socorro a desastres. Ações cooperativas, legais } \\
\text { entre nações que não possuem Tratados; projetos cooperativos } \\
\text { de gerenciamento de águas compartilhadas, irrigação e redução } \\
\text { da pobreza. }\end{array}$ \\
\hline $\begin{array}{l}\text { Apoio militar, econômico e estratégico } \\
\text { Venda de plantas ou materiais de energia nuclear; oferta de } \\
\text { instalações de bases aéreas, navais e terrestres; concessão de } \\
\text { assistência técnica ou assessoria militar; concessão de ajuda } \\
\text { militar, compartilhamento de tecnologia avançada; intervenção } \\
\text { com suporte militar em pedido governamental, conclusão de } \\
\text { acordos militares; treinamento de pessoal militar; programas e } \\
\text { planos conjuntos para iniciar e executar desarmamento. }\end{array}$ \\
\hline $\begin{array}{l}\text { Tratado internacional de águas } \\
\text { Luta conjunta em uma guerra; estabelecimento de uma junta de } \\
\text { comando ou aliança militar; condução de manobras militares } \\
\text { conjuntas; estabelecimento de mercado comum; associação ou } \\
\text { organização de alianças internacionais; estabelecimento de } \\
\text { programas conjuntos para aumento qualidade global de vida. }\end{array}$ \\
\hline $\begin{array}{l}\text { Unificação de nações } \\
\text { União voluntária entre uma nação (Estado); formando uma nação } \\
\text { com um governo legalmente instituído. }\end{array}$ \\
\hline 7
\end{tabular}

Fonte: TFDD - tradução do autor.

Disponível em <www.transboundarywaters.orst.edu $>$ Acesso em 20 out 2005. 